CHAPTER 4

\title{
The Warband in the Making of Eurasian Empires*
}

\author{
Jos Gommans
}

Ogni città riceve la sua forma dal deserto a cui si oppone

ITALO CALVINO ${ }^{1}$

Any royal authority must be built upon two foundations. The first is might and group feeling, which finds its expression in soldiers. The second is money, which supports the soldiers ...

IBN KHALDUN $^{2}$

\section{Introduction}

This volume is about the cohesion of Eurasian empires before the age of European hegemony. The latter is often conceived as being the result of a particular form of imperialism, driven by the demands of nationalism and the industrial revolution, and realized thanks to new gunpowder technology. The effective

* This essay profited enormously from the critical, encouraging, and at times quite devastating comments of my fellow travellers in the Eurasian Empires project. I also cherish the ongoing discussions on the topic with my Leiden colleagues Gabrielle van den Berg, Remco Breuker, Maurits van den Boogert, and Henk Kern. David Robinson, Tom Allsen, Walter Pohl, Eduard Alofs, and Peer Vries read the entire essay and made some very useful comments. Finally, I am also grateful to the organizers and participants of two conferences, one at the Centre for Global History at Oxford (January 2014) and one at Pembroke College at Cambridge (December 2014), which allowed me to share some of my still immature thoughts with a critical audience, among them in particular Ali Anooshahr. An earlier, abridged version of this essay will come out in India at Manohar Publishers together with some of my earlier work in The Indian Frontier: Horse and Warband in the Making of Empires.

1 'Each city receives its form from the desert it opposes', Italo Calvino, Le città invisibili (Turin, 1972) 8.

2 Ibn Khaldun, The Muqaddima. An Introduction to History, trans. Franz Rosenthal (London, 1978) 246. 


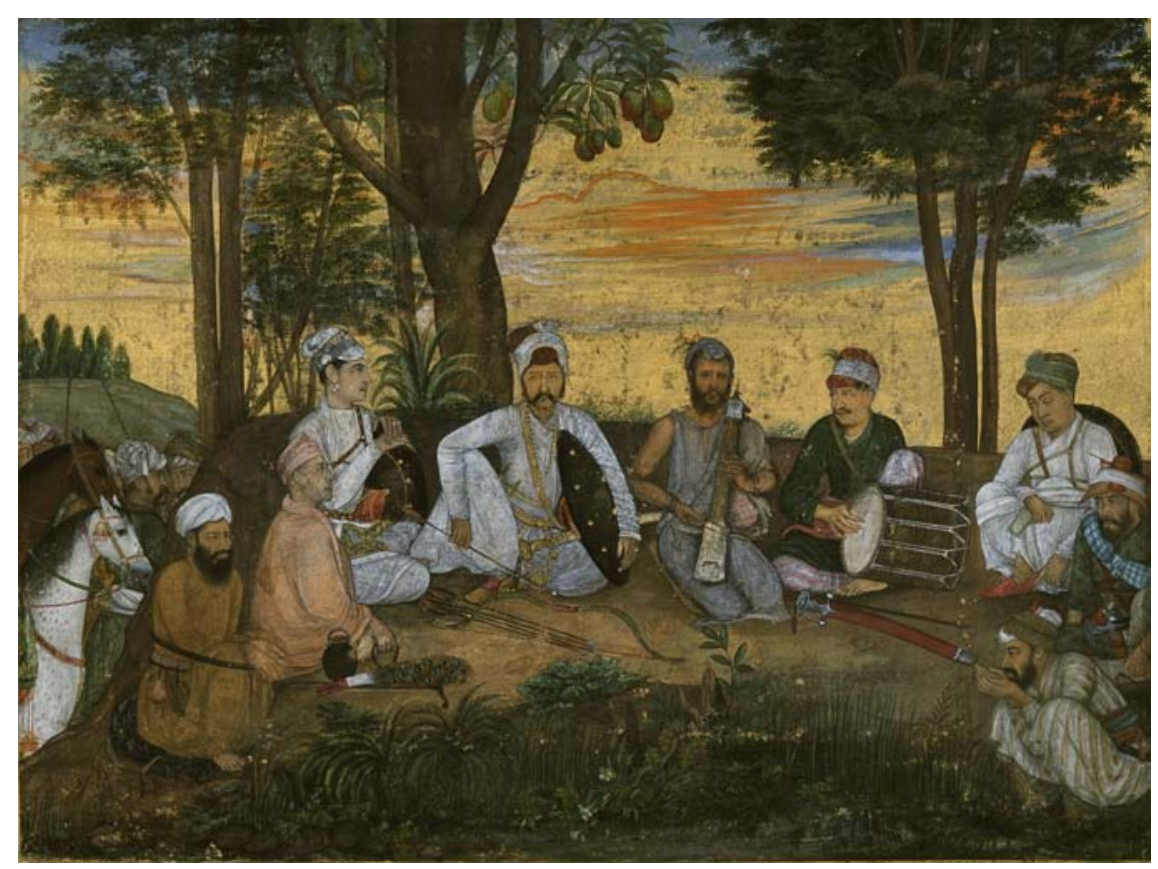

FIGURE 4.1 'Soldiers listening to music' attributed to Payag, c. 1640, from Late Shah Jahan Album (Source: Chester Beatty Library). These warriors have left their horses behind and relax while listening to music amidst a lush landscape at the fringe of the open grasslands at their back. Among them sits a yogi (on the left) with a water pot, a rosary and a peacock fan. This lyrical scene recalls the intimate camaraderie of the Mughal warband as described by its first emperor Babur. It also illustrates the way the later Mughal court continued to idealize its past as a nomadic warband.

combination of these three elements produced a paradigm of what contemporary historians would consider to be a successful empire or the 'optimal imperial outcome'. According to Charles Maier, the latter occurs 'when subject nations and their leaders voluntarily emulate the metropole's values and tastes. ${ }^{3}$ This is exactly what we experience today, as both the last remaining empires and the more recent nation states all attempt, to a greater or lesser extent, to follow the European paradigm that encompasses national cohesion, economic growth, and military strength. This raises the critical question, though, of whether imperial success has always been built on these three pillars.

3 Charles Maier, Among Empires: American Ascendancy and its Predecessors (Cambridge Mass., 2006) 66. 
In this Chapter I will address this problem by trying to detect different, premodern paradigms; i.e. paradigms that are closely related to the ideas and ideals of pre-modern historians. This more emic approach forces me to take seriously those elements that contemporary observers considered important for success. With only a few exceptions, all of them seem to agree that strong empires start with a strong group of warriors. For much of the second millennium of the Common Era there were two powerful imperial paradigms that dominated large parts of Eurasia. The first was the practical example provided by the astonishing success of the Mongolian 'world-conqueror' Chinggis Khan (c. 1162-1227); for centuries after, his was the example that other conquerors strove to emulate as it promised endless wealth and a glory that was truly imperial. It was clear to all that this Chinggisid model entailed, at the bare minimum: nomadic mobility based on a large number of well-bred warhorses mounted by well-trained horse-archers.

Yet even more crucial than this nomadic mobility was the cohesion of the conquering band of warriors and their loyalty to its leader. Here we come to the second paradigm for this study, the well-known cyclical theory provided by the North African historian Ibn Khaldun (132-1406). Inspired by some imperial best practices both in West and Central Asia, Ibn Khaldun elaborated on what he considered the secret of imperial success: the cohesion ('asabiyya) of the conquering warband. At the very beginning, when the latter was still roaming in the desert, 'asabiyya was at its strongest, and actually enabled the easy conquest of sedentary societies that lacked such cohesion. In due course, though, because of the debilitating conditions of settled life, the conquering elites lost their cohesion and could only wait for their unavoidable defeat at the hands of new nomadic conquerors from the desert, who had a much stronger 'asabiyya. Obviously, Ibn Khaldun's cyclical ideas are far from unique in global history; for example, they may remind one of Polybius's theory of predictable constitutional cycles. Elaborating on the latter, as if preparing the way for Ibn Khaldun, Tacitus made a juxtaposition of the virtuous hardy barbarian against the decadent city-dweller. Similarly, Confucianist historians were deeply aware that dynasties rose and fell like man himself, obeying a cycle of life and death that governed all animate beings. Hence, it was assumed that an imperial regime like that of the Chinese Ming would follow a general pattern: after the political and military vigour of its youth (the fourteenth century), a mature middle age of peace and stability would ensue (the fifteenth century), to be succeeded by feebleness and, eventually, fatal decline (the sixteenth century). As such, various late-imperial rulers did not passively accept their perceived fate but anxiously attempted to freeze the process with various imperial rescue missions and restorations, even though they knew very well that their dynasty was 
bound to end sooner or later. ${ }^{4}$ Being a man of his own time and place, though, Ibn Khaldun gave the theory a nomadic dynamic and brilliantly systemized and theorized the pre-existing wisdom of the influential Islamo-Persian historical tradition to organize imperial time into three stages: (1) conquest based on tribal cohesion; (2) highpoint based on justice; and (3) decline based on moral regression. Most rulers were very much aware of this scheme and anxiously tried to situate themselves in either the first or the second stage. In such a paradigm, the mere suggestion of moral decline was to be avoided at all costs as this would automatically lead to their fall.

At the heart of the practical Chinggisid model and the theoretical model of Ibn Khaldun stands the nomadic warband: a group of loyal nomadic warriors that follow their leader in the construction of an empire. My two central aims in this Chapter are (a) to study the development of the nomadic warband's cohesion before and, in particular, immediately after a conquest, and (b) to study the role of the nomadic warband in creating imperial cohesion beyond the warband, particularly its institutional and financial incorporation into the organization of empires. This immediately raises the important question of the phenomenon's relevance across time and space. How relevant are the two models for Eurasia as a whole? Is not the idea of the warband too general, and do we really need the Chinggisid model and that of Ibn Khaldun to explain it? My main argument would be that both models provide some very important keys for understanding processes of Eurasian conquest and state-formation by nomadic warbands. Hence, in contrast to what seems to be the much more universal phenomenon of the warband as comitatus as analysed by Christopher Beckwith and many others, this contribution focuses more particularly on the specific features of the nomadic as well as the post-nomadic warband within the very specific spatial limits of the Central Asian Arid Zone. ${ }^{5}$

\section{Space: Warzones and Frontiers}

It is my contention that the applicability of both models is determined by the longue durée geopolitical conditions of the Eurasian macro-region. Considering the importance of (semi-) nomadic groups and the central role of the

4 Cited from Frederic Wakeman Jr., The Fall of Imperial China (New York, 1975) 55-71. See also Mary Clabaugh Wright, The Last Stand of Chinese Conservatism: The T'ung-Chih Restoration, 1862-1874 (Stanford, 1957) 43-68.

5 For the comitatus, see Christopher I. Beckwith, Empires of the Silk Road: A History of Central Eurasia from the Bronze Age to the Present (Princeton, 2009) 17-19. Cf. Peter B. Golden, 'Some Notes on the Comitatus in Medieval Eurasia with Special Reference to the Khazars', Russian History / Histoire Russe 28 (2001) 153-170. 


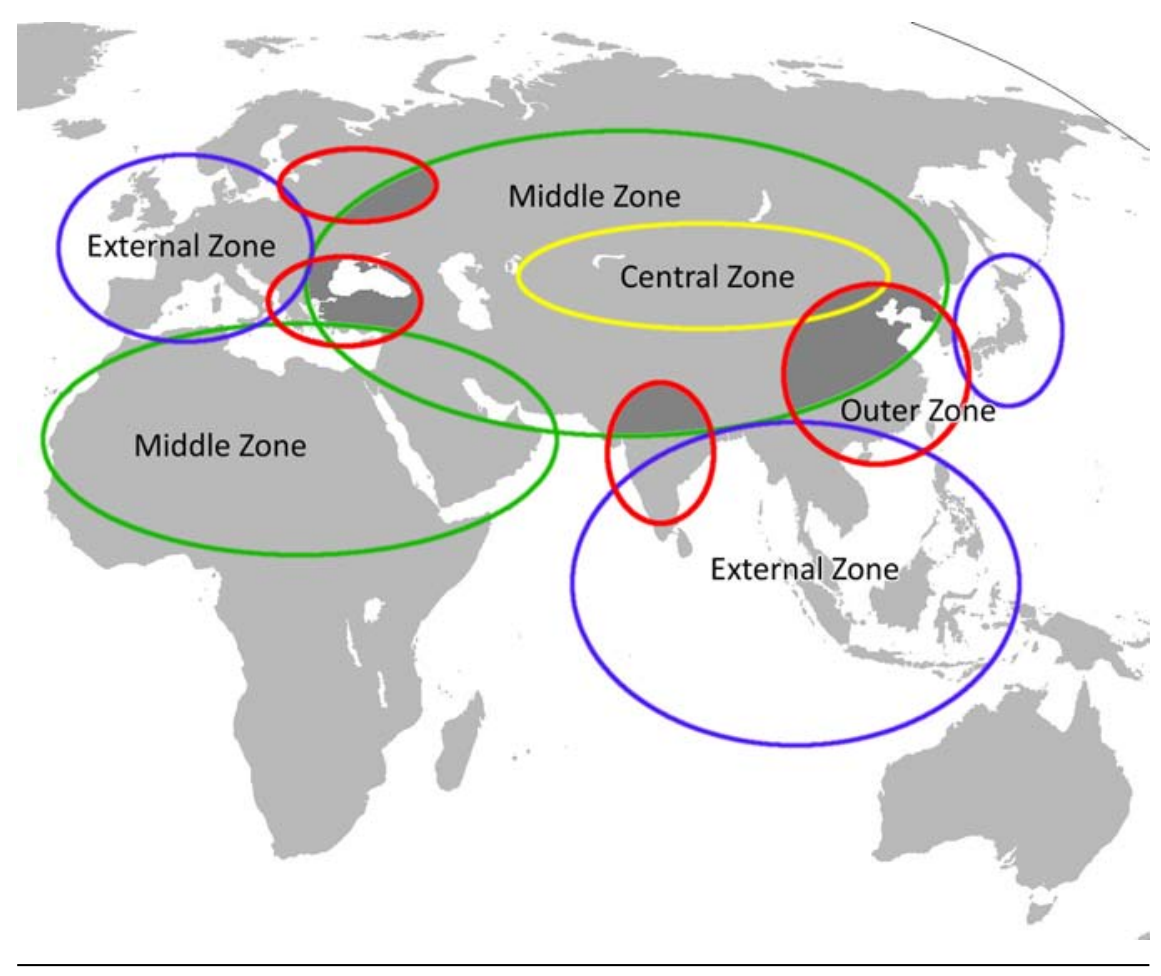

Zones

Regions

Yellow: Central Zone Nomadic: Central Eurasian Steppes

Green: Middle Zone Semi-Nomadic: Middle East - Iran - Turkestan - Northeast Asia

Red: Outer Zone Post-Nomadic: China - India - Eastern Europe - Anatolia

Blue: External Zone Sedentary: Western and Central Europe - Southeast Asia -

Japan

MAP $4.1 \quad$ Four military zones

warhorse in our period, I will differentiate between four military zones, each with a different balance between nomadic and sedentary ways of life, each with a different logic and relevance regarding our two models.

These four zones will be employed as a spatial framework in which the making and cohesion of imperial warbands will be analysed. Although the main temporal framework will be Ibn Khaldun's concept of cyclical time, I will attempt to detect some more general developments in linear time. At the base of this study, however, is my assertion that the warband became particularly 
powerful and effective in areas with a nomadic frontier and, in particular, after the end of the first millennium CE. This was the time when nomadic warriors, in particular the Mongols, Turks, Afghans, and Jurchens, gained the advantage over the armies of the settled societies that surrounded them. As they were able to tap into the increasing resources of these settled societies through trade, plunder, and tax, horse-based nomadic warbands gained unprecedented power, particularly when they managed to take the best of both worlds by carving out their empires at the very transition of the desert and agricultural zones. Although this was, at its earliest and most relevant point, focussed particularly on the Central, Middle, and Outer Zones, this development of increasing horse-based militarization even affected, albeit indirectly, the External Zone, and as such it is often discussed under the label of a 'medieval' or 'feudal' mutation. One of the main objectives of this chapter is to detect both spatial and temporal patterns in the development of this specific nomadic warband and how its changing organization played a role in the making and unmaking of empires.

The issue of the impact of Eurasian nomads on the sedentary world has already generated a tremendous quantity of studies that focused mostly on one, sometimes on two or three, but rarely embraced all the sedentary areas surrounding the Arid Zone. This is partly due to the strong philological tradition of the field of Central Asian studies in which scholarly authority is rooted in language skills. Taken the huge variety of relevant languages in this particular field, it is not at all surprising that we lack a convincing overview and that most of our conclusions are still premature and incomplete. More recently, however, we can witness an exponential growth of both regional studies and connective studies focusing on the Mongol Empire and its legacies. This essay exploits the results of these pioneering works by area specialists. At the same time, it is inspired by one of those rare comparative works that came out during the last two decades, Nomads and the Sedentary World, edited by Anatoly Khazanov and André Wink. It takes for granted that book's main conclusion that the nomadic world generated almost no institutions that could be maintained in the sedentary world. According to Wink:

Nomads can enhance the mobility of people and trade goods, and they can galvanize other elements of sedentary society. They can also support it militarily. But they cannot give it anything that resembles a selfsustaining political-institutional infrastructure. And it is for this reason that the sedentary world in the long term always won out over the nomads. 
Having stated this, though, Wink stressed the need to study the condition of so-called post-nomadism: all those cultural practices and traditions that are found among pastoral nomads who became part of the sedentary world and that are rightly or wrongly attributed to a nomadic past. ${ }^{6}$ The present essay offers a very specific study of such post-nomadism by comparing the history of the nomadic warband in East, West and South Asia as well as Eastern Europe.

The starting hypothesis of this study is the idea that the nomadic warband is a critical tool to create and sustain those Eurasian empires that surrounded the Central Asian Arid Zone. During and after a conquest the nomadic warband both extends and reproduces itself in order to encompass allied and subjugated groups. Under the conditions usually found in a sedentary empire, the original open warband encompassing the society as a whole runs the risk of being overstretched, which, in due course, may reduce it to an isolated, much more closed, and purely military institution, one increasingly dominated by the imperial bureaucracy. Hence the warband should not be studied as a given, static phenomenon but as an institution of transition. As I will explain later on, it emerges and expands under conditions of nomadic or semi-nomadic raiding, called qazaqliq by contemporaries, before markedly changing under the settled conditions of a sedentary economy. Such a transition can actually be pinned down on the map. It often occurs when moving from the Central Zone of full nomadism into the mixed economy of the Middle Zone or, as in the rare case of Chinggis Khan, straight into the Outer Zone. More usually, though, the most crucial transition occurs on the very frontier of Middle and Outer Zones, and most clearly at those places where both were still within striking distance of the Central Zone; in other words, in those areas where the Middle Zone most sharply demarcates the interface between the desert and agricultural environment. Hence, this chapter will highlight the genesis of the Chinese, Indian, Russian, and Middle Eastern empires at the four main crossroads of the Central, Middle, and Outer Zones, in, respectively, Manchuria, Khorasan, Ukraine, and Anatolia. As I will briefly discuss below, lacking such an interstitial zone with Central Eurasia, North Africa in the southern Middle Zone deserves a separate analysis.

6 Anatoly M. Khazanov and André Wink, eds., Nomads in the Sedentary World (Richmond, 2001) 295. The volume includes scholars (Peter Golden, Thomas Allsen) that produced some of the most comprehensive and inspiring comparative studies on the nomadic impact, often based on the connective momentum of the Mongol Empire. Khazanov, of course, is the historian who most thoroughly compared all the world's nomadic societies in his classic Nomads and the Outside World (Cambridge, 1984). 
Although all these regions shared a highly dynamic nomadic frontier, the specific geopolitical conditions varied significantly, and this had different effects on the way a nomadic warband amalgamated with an empire. Comparing the various frontiers with each other, the late Owen Lattimore made the insightful observation that the Great Wall of China demarcates a relatively sharp transition from sedentary agriculture to pastoral nomadism. ${ }^{7}$ Indeed, immediately north of the Wall and the Gobi Desert, the steppes of Central Mongolia provided the most favourable assembly ground for the great nomadic hordes that repeatedly changed the course of world history. As such, the Chinese frontier can be characterized as a relatively fixed outer frontier between the settled Han Chinese and the nomadic Mongols. It was only in the last two centuries that agriculture managed to expand, in fits and starts, into the northern steppes. Further east, though, in what is now Manchuria, there emerges a more interstitial region of river valleys and plains in the south, and forests and mountains in the north and east, which extends all the way to Siberia and Korea. Albeit in different ways, this mixed economy is quite common across the Middle Zone as a whole. For example, to the south-west, the Middle Zone continues into the oasis and desert landscapes of Turkistan between the Hindu Kush and Elburz Mountains, extending quite naturally through Khorasan and Iran towards the Middle East. Further south, the north-west frontier of India is not bordered by a steppe plateau but is instead encircled by mountains, while its irrigated and unirrigated lands are not set off from each other in large blocks but interconnect with one another. Moreover, the adjacent 'pastoral' economies of Afghanistan, Baluchistan, Sind, Punjab, and Rajasthan are more often semi-pastoral, and as such are distinct from the increasingly pervasive nomadism that can be observed when moving from the savannahs of the western Middle Zone towards the open steppes of the Central Zone. Although agreeing with Lattimore, I would add that in India the gradual nomadic transition created various inner frontiers, which did not support a purely nomadic society but still critically facilitated very powerful postnomadic empires with a highly dynamic military labour market based on qazaqliq. As in the case of Manchuria's interaction with the extremely prosperous China, pre-modern Indian processes of empire building were energized by an extremely rich sedentary economy along India's fertile river valleys and coastal regions. Although slightly less so than with China's outer frontier, India's inner

7 The following section builds on Owen Lattimore's insightful comments albeit, considerably adjusted for the purpose of my own research questions. See his Inner Asian Frontiers of China (Hong Kong, 1988) but more particularly his Studies in Frontier History: Collected Papers 19281958 (Paris, 1957) 148-154. 
frontiers proved relatively stable until the nineteenth century, which makes both of them stand out from the constantly retreating nomadic frontier that we discover when examining Russia.

Compared to China and India, the Russian frontier finds itself somewhere midway between these two. Like China, it has a relatively sharp distinction between the northern forest zone, dominated by settled agriculture, and the vast Pontic-Caspian steppes and savannahs to the south, dominated by nomadic pastoralism. In between, though, there is a narrow but long latitudinal stretch of mixed landscape with oak woodlands, meadows, and grasslands. At some points, the grassland of this area extends deep into the north, providing the natural pathways used for nomadic incursions. The mixture of woodland, steppe, and savannah created a semi-nomadic livestock economy alongside rainfall agriculture. Although the nomadic way of life retreated more and more towards the southern savannahs, the society that it replaced remained extremely mobile; people may have lived in houses, but they were nevertheless ready to migrate from one place to another. Not unlike India's semi-arid frontier zones, this produced the warlike society of the Ukraine based on qazaqliq, in another, but related, Russian idiom, the vagabondage of the Cossacks. ${ }^{8}$

What differentiates the Russian frontier from the Chinese and Indian is its shifting character, which is described by the Russian writer Bogdanoff, as cited by Lattimore:

Russian extensive rainfall agriculture, capable of being combined both with the grazing of livestock and with the exploitation of the forest, rapidly, though superficially, conquered enormous territories-the Russian could carry on his general farming wherever he pleased. ${ }^{9}$

Indeed, throughout our period, the Russian nomadic frontier pushed ever further towards the south and south-east. In addition to the southern flow of Russia's main river systems, this was stimulated by the fact that the temperature, soil, and moisture of the southern forest-steppe zone were more conducive to agriculture than those of the northern forests. ${ }^{10}$ Overall, though, Russian

8 While finishing my text for this volume (early 2016), I came across Joo-Yup Lee, Qazaqlï, or Ambitious Brigandage, and the Formation of the Qazaqs. State and Identity in Post-Mongol Central Eurasia (Leiden, 2016). This is the first comprehensive study of the qazaqliq phenomenon and as such it confirms my choice to see the Qazaqs and the Cossacks as one phenomenon.

9 Cited by Lattimore, Studies in Frontier History, 154.

10 For a survey of the ecological conditions in Russia and its southern frontier, see Richard 
agriculture was very poor compared to that of China and India, a basic fact of life that was considerably aggravated by the devastating effects of ongoing plagues and other epidemics. For nomadic raiders, the trouble with Russia's sedentary economy was that it never produced the kind of economic surpluses that are so distinctive for its Chinese and Indian counterparts. As a result, Russians were relatively poor peasants, and so their Tatar neighbours could only be equally poor nomads. For them the north, lacking both grazing opportunities and material resources, offered no incentives whatsoever for a permanent conquest. From the nomadic point of view, the vast Russian forest zone lacked natural anchorage points. Whereas in the east, conquering Beijing or Delhi announced the beginning of an empire, in the west, the taking of Moscow never really paid off. The Mongols and Tatars knew perfectly well what later European conquerors would learn to their utter dismay: the capture of Moscow leads nowhere!

Moving to the western parts of the Middle Zone, this region also had a different frontier dynamic. As already noted, the ecological conditions in the Middle East are not all that different from those of Turkistan and Khorasan. In this entire region, the contrast between steppe and sown can be as sharp as in China, but the irrigated agriculture is centred on oases, or strung alongside rivers that have steppe or desert on both sides. Moving into Anatolia, agriculture becomes more widespread and expands over time, but, in our period at least, it also continued to support a semi-pastoral economy that linked the towns and villages to each other and to the more open grazing lands of the Caucasus and Iran. This Anatolian frontier is thus reminiscent of the inner frontiers of India and Russia; more Indian than Russian, though, since it shares the dispersed and recurrent characteristic of the first against the more contiguous, retreating features of the latter. Overall, the sedentary economy of Anatolia was not as rich as that of India, but also not as poor as that of Russia. Hence, sustaining an extensive empire in Anatolia was possible only if one could also exploit the agricultural and commercial resources of the eastern Mediterranean.

Coming to North Africa, despite the pervasive presence of a nomadic frontier and pace Ibn Khaldun, there is one important feature that makes this region

Pipes, Russia under the Old Regime (London, 1974) 1-27; Denis J. Shaw, 'Southern Frontiers of Muscovy, 1550-1700', in: James H. Bater and R.A. French, eds., Studies in Russian Historical Geography, Volume 1 (London, 1983) 117-142; John Ledonne, 'The Frontier in Modern Russian History', Russian History 19 (1992) 143-154; David Moon, 'Peasant Migration and the Settlement of Russia's Frontiers, 1550-1897', The Historical Journal 40, no. 4 (1997) 859893 . 
as a whole very different from the Turko-Mongolian part of the Middle Zone: scale. The Middle East itself has never been able to support the sheer mass of horsepower that was produced in Central Eurasia. Of course, Arab and Bedouin nomads had a huge impact on Middle Eastern societies, in a manner very much in line with Ibn Khaldun's logic, but this primarily represents an internal dynamic, and so was not directly linked to the Chinggisid explosion that reverberated so deeply in the heartlands of China, India, Russia, and the northern Middle Zone. As in the case of Europe, Central Eurasian warbands could indeed threaten but never really conquer North Africa, partly because the latter was protected by Central Eurasian slave armies, but, more importantly, because it simply lacked the space and the resources to attract and accommodate them. Hence the North African warband comes closer to being one of the smaller and more isolated household troops of the External Zone than the huge and more open Chinggisid warband. As I will try to demonstrate, it is only at the arid fringes of China, India, Russia, and the Turkish Middle East that the Turko-Mongolian warband is an extremely potent category for analysing the creation of Eurasian empires. Beyond these regions, though, the nomadic warband either could not emerge at all, or it dissolved into other, much smaller scale and purely military units from imperial guards to regular armies.

\section{Time: The Warhorse Millennium and the Rise of the Centre}

What was the secret behind Mongol success? For most onlookers, the most obvious explanation was the quality and quantity of the Eurasian warhorse. Indeed, the Arid Zones of Eurasia were the natural breeding grounds for the world's best warhorses. ${ }^{11}$ In the same way as the ascent of infantry warfare is linked to the wider story of the Rise of the West, the age of the horse warrior is embedded in the story of what we may call the Rise of the Centre. But this also raises the question to what extent this 'Rise' was really unique for the Chinggisid era.

Domesticated about 6ooo years ago, the warhorse started its huge impact on world history about 2000 years later, drawing the war chariots of the (mostly)

11 The idea that the Arid Zone is an important historical category and that the organization of post-nomadic empires depended on their capacity to tap the horsepower that was produced there stems from my earlier work; see, in particular: 'The Silent Frontier of South Asia, c. A.D. 110o-180o', Journal of World History 9, no. 1 (1998) 1-25 and 'War-horse and Post-Nomadic Empire in Asia, c. 1000-180o', Journal of Global History 2, no. 1 (2007) 1-21 and more recently 'Continuity and Change in the Indian Ocean Basin', in: Jerry Bentley, et al., eds., The Cambridge World History: Volume vI: The Construction of the Global World, 1400-180o CE, Part 1: Foundations (Cambridge, 2015) 182-210. 
Indo-European conquerors who swept across the great sedentary civilizations of the Middle East, India, and China. A few centuries later, the chariots were replaced by the first riding nomads who, from their natural habitats in the Eurasian deserts and steppes, started to breed rather small but sturdy warhorses. At about the beginning of the Common Era, horse breeding penetrated the new Eurasian empires that started to stretch across the various frontier zones between the nomadic and sedentary worlds: from the Roman and Parthian Empires in the west, through the Kushana and Shaka Empires in the south, to the Xiongnu and Han Empires in the east. Kept and fed more and more in stalls, horses gradually became larger and stronger, specifically geared for the more heavily armoured cavalry that increasingly accompanied the lighter variety of mounted archers. Only in Western Europe and Japan, far beyond the Eurasian steppes, did the armoured knightly individual become the dominant military brand, heralding a 'feudal' age at the end of the first millennium CE.

Slightly earlier, from the sixth century onward, in regions in or immediately bordering on the Eurasian Arid Zone, the earlier development towards ever heavier cavalry was halted by the sudden emergence of two new incredibly powerful nomadic powers: the Arabs in the Middle East and the Turks in Central Eurasia. Due to the sheer number and quality of the Central Eurasian horse, it was in particular the Turks who were able to dominate military practice in a vast area that stretched from the Hungarian plain to the Great Wall of China in the northern steppes zone, and from Egypt to southern India in the southern desert zone. By far the most prominent ethnic group among them was the Qipchaq Turks who, in the thirteenth century, provided state-of-the-art horse warriors, and even rulers, to states as far-flung as the Kingdom of Hungary, the Mamluk Sultanate in Egypt, and the Delhi Sultanate in India. Much later, the most powerful of the post-nomadic empires, the Ottomans and the Mughals, continued this already rich tradition of Turkish empire-building, and even the Iranian but heavily Turkified dynasty of the Safavids could only follow in the footsteps of their Seljuq (eleventh - twelfth century), Qara Quyunlu, and Aq Quyunlu (fourteenth-fifteenth century) predecessors and base their might on the Turkish man- and horsepower found in their northern territories. In all these cases, Turkification automatically implied militarization and a growing tendency towards Turkish or Turkified rulers across the whole Eurasian continent, who conspicuously demonstrated their outstanding martial qualities, be it in actual practice on the battlefield or imagined in sumptuous rituals, heroic poetry, or austere architecture. In Northeast Asia, the machismo of the Turks finds an almost perfect parallel in the military prowess of the Mongolian Khitans and Tungunsic Jurchens who provided the horsepower and dynasties for, respectively, the Liao and the Qara Khitai, and the Jin and Qing Empires. 
However, the absolute highpoint of Central Eurasian power was not a Turkish but a Mongol achievement: the unprecedented thirteenth-century expansion of the nomadic empire under the brilliant leadership of Temüjin, better known as Chinggis Khan. But was there really that much difference between Mongol and Turkish expansion? Our use of the contraction 'Turko-Mongol' is partly informed by the contemporary Arabic and Persian sources, which repeatedly convey the belief that Mongols and Turks belonged to one and the same race. For example, the historian Rashid al-Din (1247-1318), who was very close to the scene, explicitly stressed unity in diversity:

Although the Turks and the Mongols and their branches are similar and their language is of the same origin, the Mongols being a kind of Turks, there is yet much difference and dissimilarity between them ... These Mongols were just one people amongst the Turkish peoples.

Rashid al-Din also suggests that it was simply the strongest in the group who determined that group's ethnic identity, as he adds that when the Mongols rose to such power and eminence, 'most of the Turkish peoples were called Mongols.' ${ }^{12}$ Moving further westwards, we find a similar ethnic amalgamation taking place with the emergence of the term Tatars, which did not refer to the more specific Mongol 'tribe' that fought Chinggis Khan, but was a more generic term indicating a broad mixture of primarily Turkish, but also other ethnic groups, all of them Muslims, beyond the southern frontiers of the sedentary and Christian states of Muscovy and Poland-Lithuania. Indeed, whether Mongols, Turks, or Tatars, all these groups built their power on the capacity to mobilize more horse warriors than ever before. Despite some advances in equipment, such as the stirrup, technology and tactics basically remained the same. The key weapon remained the composite bow, tactics continued to be based on a combination of heavy and light cavalry, the latter of which was extremely mobile, wheeling around the enemy while delivering continuous showers of deadly arrows against them. Hence, the reason this has been called a horse-warrior revolution derives not from any quality but their sheer quantity. So if there was a revolution, it really was a revolution of size: the Mongols merely provided the most spectacular example of a much older and wider Turko-Mongolian development that started as early as the seventh century but, for more than

12 David Ayalon, 'The Great Yāsa of Chingiz Khan. A Reexamination(Part C1)', Studia Islamica 36 (1972) 126; David Ayalon, 'The Great Yāsa of Chingiz Khan. A Reexamination (Part C2)', Studia Islamica 38 (1973) 149-15o. 
a millennium, continued to have a tremendous impact on patterns of stateformation in the entire Eurasian continent.

How can we explain the fact that Turko-Mongolian conquerors managed to operate the biggest cavalry armies that the world had ever seen? It is my contention that it was primarily because of their organizational skill that they were able to tap into the rich agrarian and commercial resources of the sedentary worlds that they first plundered and subsequently conquered. As such, it rather follows the first part of 'the circle of justice' as described in Iranian advice literature: 'there is no kingship without an army, no army without revenues.13 Indeed, conquering an empire was one thing, ruling an empire quite another. The main challenge was how to link the already existing fiscal institutions of the sedentary world to the nomadic armies, which was extremely important, as the nomadic conquerors could not risk giving up their trump card: their horsepower.

Here we may speculate whether the earlier 'frontier states' of Turks, Khitans, and Jurchens, as well as other semi-nomadic, 'cooked' (shou) dynasties, paved the way for the Mongols, who could simply build on an already proven infrastructure to bridge the nomadic and sedentary constituents of their polities. ${ }^{14}$ This is certainly suggested in the early Song accounts of the Mongols who are depicted as a 'new kind of northerners': true nomads ('noble savages'), not yet spoilt by the corrupt pseudo-nomadic officials of the Jurchen Jin. ${ }^{15}$ Whatever the case may be, these Jurchen and Turkish frontier states clearly showed the Mongols how to manage a complicated balancing act in which one had to keep one leg in the nomadic world in order to procure horsepower, while setting the other firmly in the sedentary to be able to collect sufficient revenues to pay for it. Obviously, this exercise required specialized administrators, sophisticated people of the pen, who were both outsiders and insiders, and who were able to read and write in the language of the conquerors and the conquered. Before turning to our four concrete cases of Turko-Mongolian empire-building in China, India, Russia, and the Middle East, let me first elaborate further on our two models in order to make the latter more operational and testable.

13 It continues as follows: 'there is no revenue without subjects, no subjects without justice, no justice without a king'.

14 See the suggestive comments on the Qara Khitai Empire ('The Qara Khitai established an empire in Central Asia that for the first time joined the worlds of China, the Inner Asian nomads and Islam') by Michal Biran, The Empire of the Qara Khitai in Eurasian History: Between China and the Islamic World (Cambridge, 2005) 204-206.

15 Chad D. Garcia, 'A New Kind of Northerner: Initial Song Perceptions of the Mongols', Journal of Song-Yuan Studies 42 (2012) 326, 330. 


\section{Theory and Best Practice: Ibn Khaldun and Chinggis Khan}

\subsection{Ibn Khaldun's Model: The Sword and the Pen}

For nomadic conquerors, becoming administrators themselves was never a serious option as there was always the apprehension that they would lose their martial prowess and, with that, their very identity as true Turks or Mongols. Examples abound that show the nomads' fear of devitalization, which they believed would inevitably accompany the sedentarization process. Take, for example, Bilge (r. 717-734), the ruler of the second Turkic khaganate, who advised his people to remain apart from the settled world, as recorded in the eight-century Orkhon inscription:

Because some ignorant people accepted this invitation and came near the plain in order to settle (in China), many of your people are dead. If you go into that country, O Turkish people, you will die. But if you dwell in the land of the Ötüken and send caravans and convoys, and if you stay in the forest of Ötüken, where there is neither wealth nor trouble, then you will continue to preserve an everlasting empire, O Turkish people, and you will always eat your fill.

In the unfortunate case that one could not avoid such an encounter with the sedentary world, it was better to stick to old customs, as was the approach of Xiéli or Illig Khagan (r. 620-63o), the last ruler of the Eastern Turkic Khaganate, who had to surrender to the Tang but still managed to:

Pitch his felt tent in the middle of the palace, (before he) fell into a state of profound sadness, and could endure his fate. Surrounded by the people of his household, he chanted plaintive airs and wept with them. ${ }^{16}$

This is repeated frequently in later sources, all of which boast of the martial qualities of the Turkish nation, and among which perhaps the most graphic depiction is that of the eleventh-century Arab historian Ibn Hassul:

The most amazing thing about them [the Turks] is that nobody has ever seen a pure Turk (turkiyyan khälișan) who had been afflicted by effeminateness (takhnith), and this in spite of the fact that this disgrace is

16 Jean Cuisenier, 'Parenté et organisation sociale dans le domaine turc', Annales. Économies, Sociétés, Civilisations 27 (1972) 932. Translation by Elborg Forster. 
general, and this affliction is common among all the peoples we saw, especially those of Gilan. If, however, one does find traces of effemination (ta'nith) in any Turk in his speech, in his hints, in his dress or in his jewellery, he is proved to be one of the Turks of a mixed breed, who thoroughly mingled with the race of their neighbours, the local inhabitants of those lands. ${ }^{17}$

In the Islamic world, the threat of being assimilated into a settled society was often expressed in the dualism between Mongol law (yasa) and Islamic law (shari'a $a .{ }^{18}$ Indeed, the specific underlying principle of the so-called Chinggisid yasa was the maintenance of a nomadic military culture that was fundamentally opposed to the values of settled society. ${ }^{19}$ Equally prominent, though, is the discourse that distinguishes between the civilized Tajik or Persian and the rustic Turk or Turani, as reflected most famously in Firdausi's Shahnamah, and as quintessentially formulated in a Turkish proverb provided by the eleventhcentury Turkologist Mahmud al-Kashghari: 'Just as the effectiveness of a warrior is diminished when his sword begins to rust, so too does the flesh of a Turk begin to rot when he assumes the lifestyle of an Iranian.'20

Much later, Qara Usman (r. 1378-1435), the founder of the Aq Quyunlu Empire, could only agree, as he advised his sons: 'Do not become sedentary, for sovereignty resides in those who practice the nomadic Turkmen way of life.21

As we have seen, the most sophisticated exponent of the idea of a process of effeminization was Ibn Khaldun. For him, the unavoidable decline of group feeling ('asabiyya) among the conquering tribe was linked to the declining role of the people of the sword and their replacement by the people of the pen:

It should be known that both 'the sword' and 'the pen' are instruments for the ruler to use in his affairs. However, at the beginning of the dynasty, so long as its people are occupied in establishing power, the need for 'the sword' is greater than that for 'the pen'. The same is the case at the end

17 David Ayalon, 'The Mamlūks of the Seljuks: Islam's Military Might at the Crossroads', Journal of the Royal Asiatic Society 6 (1996) 314.

18 See for example the recent discussion in Guy Burak, 'The Second Formation of Islamic Law: The Post-Mongol Context of the Ottoman Adoption of a School of Law', Comparative Studies in Society and History 55, no. 3 (2013) 579-6o2.

19 See also the comment by Ayalon, 'The Great Yāsa of Chingiz Khan (Part C2)', 135.

20 Maria E. Subtelny, Timurids in Transition:Turko-Persian Politics and Acculturation in Medieval Iran (Leiden, 2007) 29.

21 John E. Woods, The Aqquyunlu: Clan, Confederation, Empire (Salt Lake City, 1999) 17. 
of the dynasty when its group feeling weakens and its people decrease in number under the influence of senility. The dynasty then needs the support of the military. The dynasty's need of the military for the purpose of protection and defence is as strong then as it had been at the beginning of (the dynasty) when its purpose was to become established. In these two situations 'the sword' thus has the advantage over 'the pen'. At that time, the military have the higher rank. They enjoy more benefits and more splendid fiefs.

In the mid-term of the dynasty, the ruler can to some degree dispense with 'the sword'. His power is firmly established. His only remaining desire is to obtain the fruits of royal authority, such as collecting taxes, holding (property), excelling other dynasties, and enforcing the law. 'The pen' is helpful for (all) that. The swords stay unused in their scabbards, unless something happens and they are called upon to repair a breach. The men of the pen have more authority. They occupy a higher rank. They enjoy more benefits and greater wealth and have closer and more frequent and intimate contact with the ruler. ${ }^{22}$

In this long quote, Ibn Khaldun links the fortunes of the peoples of sword and pen to the natural cycle of empires. The group feeling among the warriors of the desert enables them to conquer the settled societies around them. After a conquest, though, more and more of the people of the sword will be replaced by people of the pen, which may optimize the management of the empire, but will also soften the group feeling of the conquering elites and thus make them vulnerable to renewed conquest from nomadic outsiders with a stronger group feeling. ${ }^{23}$

What is perfectly clear is that the elite groups living on the edge of the deserts and steppes of the Arid Zone were well aware that after a conquest warriors tended to lose their freshness and vigour. As indicated by Ibn Khaldun, the problem was often perceived as a power struggle between the warlike people of the sword, who were often direct descendants of the conquerors, and the civilized people of the pen, often recruited from the conquered. For example, the sword-pen dichotomy was a major theme in the Persianate political wisdom literature (akhlaq) that experienced a revival immediately after the Mongol conquest. The most influential of these traditions is that of the thirteenth-

\footnotetext{
22 Ibn Khaldun, Muqaddima, 213.

23 For a pen-based view on this important dichotomy, see chapter 5 in this volume by Maaike van Berkel.
} 
century writer Nasir al-Din al-Tusi who stresses that the king should always keep an equable mixture of the four classes of mankind-very much like the four humours of the human constitution. As well as the men of the pen and the men of the sword, these consisted of the men of negotiation and men of husbandry. ${ }^{24}$ As a comment on Nasirean ethics, later mirrors for princes confirmed the symbiotic relationship between pen and sword, although they increasingly tended to prefer the pen over the sword, as, for example, was the case with the scholar-bureaucrat Kashifi (d. 1504-1505), who actually warns against the latter: 'Men of the pen never aspire to take over a kingdom, whereas men of the sword often do; moreover, men of the sword empty a sultan's treasury, while men of the pen fill it. 25

The sword-pen relationship is hardly exclusive to the Islamic world. In the case of China, a similar tension is expressed in the dichotomy between $w u$ (the martial domain) and wen (the civil domain), which became particularly acute during the conquests of the Khitans (Liao), Jurchens (Jin), and Mongols (Yuan), and later under the Manchus (Qing). It is interesting to read the words of the Yuan historiographer who almost repeats Ibn Khaldun's observation when he states:

Jin established the dynasty by use of $w u$. In this it did not differ from Liao. But it was able to establish institutions drawing on both Tang and Sung, achieving in some things what Liao had not attained. This was accomplished with wen, not with wu. [Confucius in the Tso] Commentary said: If one says it without wen, he will not be able to practice it extensively. ${ }^{26}$

The Yuan historiographers saw wen as a process by which the initial $w u$ of the conquerors was civilized. So wen involved learning specific skills: the creation of a chain of command, the adoption of civil speech, the use of administrators, the extension of central authority, the creation of a bureaucracy, the accumulation of books, the welcoming of the learned, the recognition of cultural tradition, the spread of education, the rise of the literati to de facto leadership, and, finally, the creation of a cultural legacy. All this was seen as the achievement of the civil order, of benefit both to the state and people, and as such it

24 Nasir al-Din al-Tusi, The Nasirean Ethics by Nașir ad-Dīn Ṭūsī, trans. G.M. Wickens (London, 1964) 230, 327.

25 Maria E. Subtelny, 'A Late Medieval Persian Summa on Ethics: Kashifi's Akhlāq-i Muhsinin̄', Iranian Studies 36, no. 4 (2003) 6o5.

26 Peter K. Bol, 'Seeking Common Ground: Han Literati under Jurchen Rule', Harvard Journal of Asiatic Studies 47 (1987) 487. Based on the Jin shih. 
was sharply contrasted with military rule. Like Ibn Khaldun, the Jurchens themselves were very much aware of both the historical sequence and the natural complementarity of $w u$ and wen. This is illustrated by one of the questions in the first Jurchen-language examination that they introduced: 'Our dynasty settled all under heaven with spirited $w u$; His Majesty is bringing comfort to all within the seas with wen virtue. Wen and $w u$ are both employed.'27

At about the same time, another version of $w u$ was influential in the creation of empires on the north-western side of the Eurasian steppes, and particularly along the fringes of the Russian forest belt. In thirteenth- and fourteenthcentury Muscovy, it gave rise to the introduction of a dual administrative system between, on the one hand, military tasks, which were in the hands of the so-called basqaq, and, on the other, civilian tasks that were in the hands of the darugha. ${ }^{28}$ Although Russia's dual administration may have been built on Mongol antecedents, we may wonder about the nomadic nature of this duality. Was it really that different from the experience of the European Middle Ages where a similar distinction between pen and sword emerged between, on the one hand, the knights who held land by right of blood and, on the other hand, the clerics of profession and ordination? ${ }^{29}$

What made the European situation different is shown by the situation at its fringes, where the kings of Hungary, Georgia, and, indeed, Muscovy attempted to fight the growing power of the landed nobility by inviting nomadic Qipchaqs (Cumans) into their territories and making marriage alliances with them. ${ }^{30}$ This suggests that it was much easier for the mounted warriors in Europe to become firmly rooted in their landholdings with no eagerness whatsoever to maintain nomadic purity against an imagined bureaucratic other. In most of Eurasia, bureaucrats fashioned themselves as preservers of an administrative order that was repeatedly demolished by foreign warriors. By contrast, much

27 Bol, 'Seeking Common Ground', 488.

28 Donald Ostrowski, Muscovy and the Mongols: Cross-cultural Influences on the Steppe Frontier, 1304-1589 (Cambridge, 1998) 36-63.

29 R.I. Moore, 'The Transformation of Europe as a Eurasian Phenomenon', Medieval Encounters 10 (2004) 89-9o. See also the discussion in Past \& Present following T.N. Bisson's 'The "Feudal Revolution", Past \& Present 142 (1994) 6-42, which demonstrates how European historiography is still captivated by national perspectives and traditions.

30 Nora Berend, 'Cuman Integration in Hungary', in: Khazanov and Wink, eds., Nomads in the Sedentary World, 110-111. King László IV (1272-1290) was half Cuman and during his reign Cumans gained unprecedented importance, as neugerii or members of his military bodyguard. See also Nora Berend, At the Gate of Christendom:Jews, Muslims and 'Pagans' in Medieval Hungary, c. 1000-c. 1300 (Cambridge, 2001) 145, 183. 
of the bureaucracies in Europe were staffed by the disinherited relatives of the landed elites. ${ }^{31}$ These circumstances may have contributed to Maaike van Berkel's observation that compared to the Islamic and Chinese cases, European people of the pen had a relatively weak professional awareness. ${ }^{32}$ Indeed, there is no European discourse that comes anywhere near the dichotomy between nomadic Turk or Mongol versus sedentary Tajik or Chinese. Indeed, as we will see below, the foremost purpose of the nomadic warband after a conquest was to forestall the process of gentrification in which the imperial aristocracy settles permanently and takes root in landed properties. High time to turn to the specific characteristics of the nomadic, Turko-Mongolian warband.

\subsection{The Chinggisid Model: Scale and Ethnic Engineering}

How did nomadic conquerors cope with this unavoidable dichotomy between the military and administrative organization in their newly won empires? The vehicle that had gained them their empires was the keshik. It was a conscriptbased elite made up of the personal followers and guardsmen of the war leader who trained and paid them, often by distributing booty among them. The keshik consisted of non-tribal companions (nökörs) and constituted the leader's personal household. They were recruited not on the basis of family or a hereditary position but purely on their loyalty and talent. Indeed, intensely personal ties between leaders and followers were at the heart of the warband's cohesion. Actually, it was demonstrated in a re-enactment of family life manifested in every day social interaction involving eating, drinking, clothing, and in the frequent collective celebrations of shared experiences, adventures, hunting encounters, great feasts, and drinking bouts, hangovers included. All this was commemorated by material awards, rewards, and other forms of public redistribution. Despite the appearance, not kinship but common experiences, particularly dramatic and dangerous ones, generated solidarity. As in that wellknown classical-Chinese verdict on the barbarians: 'these people despise the old and take joy in the strong', not descent but talent counted. ${ }^{33}$

31 Moore, 'Transformation of Europe', 88-89. However, in this case Moore sees parallels with China as a common 'need for an old aristocracy to transform itself in order to renew its access to power and wealth' (page 95). In China, though, there is always the threat of a devastating nomadic conquest that Europe lacks.

32 See chapter 5 by Maaike van Berkel in this volume.

33 The information on the keshik is entirely based on the pioneering work of: Thomas T. Allsen, 'Guard and Government in the Reign of The Grand Qan Möngke, 1251-1259', Harvard Journal of Asiatic Studies 46 (1986) 495-521; S.M. Grupper, 'A Barulas Family Narrative in the Yuan-shih: Some Neglected Prosopographical and Institutional Sources on Timurid 
As stressed already, the most important ingredient of 'the strong' was the warhorse. Its importance is indicated in some of the earliest titles given within the keshik of Chinggis Khan, which included grooms, herders of horses (ăgtačin), and, more specifically, herders of geldings (aduğučin). ${ }^{34}$ Interestingly, and perhaps significantly, it was in the course of retrieving horses stolen from his family that Chinggis Khan started his keshik in the early 118 os by recruiting Bo'orchu, the very first of his many nökörs. ${ }^{35}$ But more important than its equine nature is the fact that all titles within the keshik express a physical closeness to the leader. This is shown in titles such as cooks, chamberlains, and other so-called ichki's (insiders), which were most clearly manifested in the rotation of personal guard duties, which created another set of honourable titles: night-guards and day-guards.

Historians have interpreted keshik as the typical Indo-European comitatus, also Männerbund in German or druzhina in Russian. Thus, the phenomenon seems not to be particular to Turko-Mongolian nomads. ${ }^{36}$ Indeed, there is an overall scholarly consensus that the keshik has a much older history, and even could be quite universal in nature, as it can be traced far beyond Central Eurasia, and even beyond the Indo-European heartlands. Staying aloof from the controversies surrounding its origins, it is my contention that the keshik as an open, meritocratic institution fares best in the socio-political context of (semi-) nomadic vagabondage, in Turkish expressed as qazaqliq. ${ }^{37}$ Another term related to qazaqliq is the Arabic word ghaza — not to be confused with its later theological rationalization of jihad as in the case of early Ottoman history. Both refer to the adventurous life of a charismatic hero in the wilderness who, through his success, is able to attract a following of retainers called qazaq, cossack, ghazi, or any other label that indicates free association. The keshik loses its strength, though, the moment it gains a foothold in sedentary society. This

Origins', Archivum Eurasiae Medii Aevi 8 (1992-1994) 11-99; Woods, The Aqquyunlu; P.B. Golden, “'I will give the people unto thee”: The Činggisid Conquests and their Aftermath in the Turkic World, Journal of the Royal Asiatic Society 10, no. 1 (2000) 21-41; Charles Melville, 'The Keshig in Iran: The Survival of the Royal Mongol Household', in: Linda Komaroff, ed., Beyond the Legacy of Genghis Khan (Leiden, 2006) 135-164; and Subtelny, Timurids in Transition. Much of this goes back to much older literature inspired by B. Vladimirtsov, Le régime social des Mogols; Le féodalisme nomade (Paris, 1948). I very much profited from Allsen's further comments on this phenomenon by email.

34 Grupper, 'A Barulas Family Narrative', 39.

35 Allsen, 'Guard and Government', 513.

36 Most forcefully in Beckwith, Empires of the Silk Road.

37 Subtelny, Timurids in Transition, $28-32$. 
also explains the well-known Tatar strategy of kazakcikmak: withdrawing to the steppes in order to regain your strength, a phenomenon that will immediately be familiar to those with a knowledge of Indian epics, where princes conquer kingdoms after the return from exile in the wilderness. ${ }^{38}$ Although qazaqliq can be seen as universal, it is at its most effective and enduring in the specific geopolitical conditions of the Arid Zone, hence its ongoing association with its Central Eurasian past and the repeated fear of losing one's strength by being assimilated into the settled world. Obviously, this fear makes the necessary linking of sword and pen all the more challenging for nomadic conquerors, who not only want to conquer a sedentary empire, but also want to rule one without losing the original strength and cohesion of their keshik. This was quite a challenge since the keshik is so closely associated with qazaqliq, a way of life that could not be tolerated under the new sedentary order.

Hence, it is my contention that there was something unique about the empires that were carved out by nomadic or semi-nomadic conquerors. In cases where the imperial household was not able to repeatedly recruit fresh nomadic horsepower, it had to accept that its military power would be increasingly based on a hereditary and rooted military aristocracy. On the other hand, imperial households that were built on significant numbers of highly mobile mounted warriors had a much tougher hold on the society and could more easily disregard hereditary rights and privileges. Thus, for these so-called postnomadic imperial households it was crucial to retain the 'spirit of the steppes', which involved (a) the meritocratic recruitment of mobile horse warriors, and (b) their (re)organization into artificially constructed groups that were as closely attached to the personal household of the ruler as possible. For the purpose of the present argument, both the keshik and these freshly fabricated, subsidiary military groups are perceived as nomadic warbands. Even after conquering or settling in sedentary surroundings, some of these 'conscriptive' groups, such as the Manchu Banners or the Russian Cossacks, retained their highly meritocratic and personalized (i.e. non-tribal) spirit, and as such can still be seen as post-nomadic avatars of the nomadic warband.

So the important question remains: how to govern after a nomadic conquest? The obvious answer would be to convert the keshik into an imperial army and administration while, at the same time, retaining its core ingredients that would ensure ongoing personal loyalty and counteract the assimilative pull of settled civilization that threatened to draw the nomadic elite into its snare. In

38 Halil Inalcik, 'The Khan and the Tribal Aristocracy: The Crimean Khanate under Sahib Giray I', Harvard Ukrainian Studies 3/4 (1979-1980) 452. 
line with the pioneering work of Peter Golden, we suggest that it was indeed Chinggis Khan who perfected the institution of the keshik, and did so on an unprecedented scale, ${ }^{39}$ by a thorough reshuffling of the 'tribal' components of his following. ${ }^{40}$ The result of this was the creation of decimal military units as artificial tribal formations that consisted of a well-engineered mixture of original tribes and other, defeated, groups. ${ }^{41}$ The leaders of these subsidiary warbands of 10,000, 1,000, and 100-here for mere convenience called tümens after its biggest contingent-had to send their brothers, sons, and the best of their own companions and mounts as, respectively, hostages and security to the chief Khan or Khaghan. The hostages were incorporated into the imperial keshik, sharing a tent and table with the Kaghan. At the same time, their sisters and daughters often married into the dynastic line, some of them serving as wet nurses, meaning their sons shared their mother's milk with the sons of the Khaqan, thus being turned into foster brothers of the royal princes. ${ }^{42}$ Others became concubines in a system where polygamy flourished among those able to afford it. ${ }^{43}$ From the point of view of most sedentary societies, these Mongol women were conspicuously present at court and, using Rossabi's apt characteristic, made an extraordinary 'assertive, worldly and able impression'. Although some of them gained powerful positions for themselves and for their sonseven the sons of concubines were considered legitimate sons who received part of their father's property — the privilege of legitimate succession remained

Golden, "I will give the People", 21-41.

40 The term 'tribe' is highly problematic. The common term used in the early Mongol sources is irgen, which indicates 'a community of common 'shape, form, vocabulary, dialect, customs and manners'. Lhamsuren Munkh-Erdene, 'Where Did the Mongol Empire Come From? Medieval Mongol Ideas of People, State and Empire', Inner Asia 13, no. 2 (2011) 211237-partly cited from Thackston.

Of course, the decimal system as such was not a Chinggisid invention as it was used already by the Xiongnu.

42 Subtelny, Timurids in Transition, 35.

43 'Pure' descent was primarily determined by the father, although the maternal lineage also remained important (e.g. Babur's maternal descent from Timur). Interestingly, this exogamous policy is still visible in the Y-chromosomal lineage that goes back to Chinggis Khan and can be traced in $8 \%$ of the male population of the Central Eurasian region. The existence of this Chinggisid genetic lineage is as telling for Chinggisid patrilineal descent rules as the non-existence of other such lineages is for the Chinggisid policy of ethnic engineering. T. Zerjal, Y. Xue, G. Bertorelle, et al., 'The Genetic Legacy of the Mongols', American Journal of Human Genetics 72, no. 3 (2003) 717-721; see also E. Heyer, P. Balaresque and M.A. Jobling, 'Genetic Diversity and the Emergence of Ethnic Groups in Central Asia', BMC Genetics 10 (2009) 49. 
with the chief wife. Hence, despite the absence of monogamous marriage, only Chinggis Khan's sons by that wife were regarded as eligible for the succession. ${ }^{44}$

So Chinggis Khan's first innovation was one of scale. He expanded his keshik from a mere eighty night-guards and seventy day-guards in 1189 to a permanent administrative unit of 10,000 men in 1206, which amounted to about one-tenth of all active military forces. At the same time, beyond the Chinggisid line itself, the crucial meritocratic principle of the keshik was maintained or, as the Secret History of the Mongols has it, 'those shall be enlisted who are clever and attractive of appearance.' As big as the keshik grew, it remained a personal army, subordinate and loyal to Chinggis Khan alone. As vast as the empire grew, the old practice of organizing repeated physical contact was maintained; this was described by the thirteenth-century Walloon globetrotter William of Rubruck, who reported that all nobles stationed anywhere within a two-month journey of the capital Qara Qorum were obliged to assemble each summer at the court in order that Möngke, one of Chinggis Khan's successors, might drink and sup with them, bestow garments and presents upon them, and display his great glory ${ }^{45}$ Meanwhile, members of the extended keshik of 10,000 served as a pool of loyal managers, both for the military and for the civil administration. As Thomas Allsen so aptly observes, the keshik remained 'the training ground, proving ground and recruitment ground for central government personnel. ${ }^{1} 6$ As such, it served as a top-layer of various kinds of special, personal envoys (wakils) and controllers (darughachis) who supervised the existing hierarchy of both military and civil administration. Chinggis Khan was known to have expressed it as follows: 'My guardsmen are higher than the external commanders of thousands. The escorts of my guardsmen are higher than the external commanders of hundreds and of tens. ${ }^{\prime 7}$ Thus, a crucial part of the system was a structural doubling as well as the overlapping of functions; shadow officers from the keshik, who served as a check on the regular administrator, also had to keep an eye on their closest colleagues with similar functions. As is often observed by later analysts, Mongolian officials were generalists rather than specialists.

44 David Morgan, The Mongols (Oxford, 1990) 40; Morris Rossabi, 'Khubilai Khan and the Women in his Family', in: W. Bauer, ed., Studia Sino-Mongolica: Festschrift für Herbert Franke (Wiesbaden, 1979) 153-180. The same idea continued under the Mughals in India and, under more secluded circumstances, under the Ottomans. For the important consequences of different marriage patterns in Europe, see Duindam, chapter 2 in this volume. Allsen, 'Guard and Government', 518.

46 Allsen, 'Guard and Government', 517.

47 Grupper, 'A Barulas Family Narrative', 44-45, 57. 
Chinggis Khan's second major innovation was his widely implemented policy of ethnic engineering: the breaking up of old patterns of ethnic organization and reconstituting them into new subsidiary warbands such as the tümens. This is what Golden calls the 'nökörization of the tribal fighting force'; the imposition of the non-tribal, personal principle of the warband onto the existing tribal organization. ${ }^{48}$ This is forcefully argued by Lhamsuren Munkh-Erdene, who demonstrates the existence of a category of people called felt-tent, or ulus in Mongolic, who became Mongol ulus only after being administratively organized into ninety-five units of a thousand. As a result, the term ulus itself has not an ethnic but a political meaning, that of a 'community of the realm'; that is, a political community formed by the state. ${ }^{49}$

As will be discussed below, there is growing doubt as to whether the preexisting structure of society was really based on 'tribes', and so it must be wondered to what extent Chinggis Khan was really that innovative in this regard. However, the difference between the ideas of the original core warband of the ruler (keshik) and these new subsidiary warbands (tümens) was that the latter was not freely but forcibly associated with the Khaghan, a process engineered by the latter, who was assisted by the men and women of his own tümen, the keshik. In principle, though, the tümen signifies the successful repetition and trickling down of the keshik at the level of the ruler's followers, and as such will be studied here as an important and integral ingredient in the legacy of the Chinggisid and the Turko-Mongolian warband.

\subsection{Transition}

Central to the present argument is the view that many of the Eurasian Empires of the period 1200-180o were not only inspired by long-standing Roman, Islamo-Persian, or Chinese traditions - a fact all too often stressed by our present-day area studies - but also by the nomadic legacy of the keshik as created by Chinggis Khan. Although the keshik was an ancient institution that was to flourish particularly in the socio-political context of Central Eurasian qazaqliq, Chinggis Khan expanded the institution to an imperial level and imposed it ruthlessly on both the old aristocracies and the new imperial administration. It should not be forgotten, however, that even Chinggis Khan soon made compromises with his own model. Although in principle the members of the keshik derived their honour and position from their talent and personal loyalty to Chinggis Khan, the latter made sure that his new world order was perpetuated:

48 Golden, "I will give the People", 23.

49 Munkh-Erdene, 'Where did the Mongol Empire come from?', 211-237. 
As for my 10,0oo personal guardsmen, who have come selected to become personal servants in my presence from the ninety-five thousands, the sons who will have sat on my throne henceforth - to the descendants of my descendants - shall consider these guardsmen as a legacy and give them no cause for dissatisfaction and take excellent care of them. ${ }^{50}$

Although this arrangement undermined the meritocratic principle of the nomadic warband, it also explains the endurance of the Chinggisid tradition; for example, S.M. Grupper has shown how Timur's legitimacy was based on ancestors who had served as nökörs in the Chinggisid keshik for five generations. But by far the most crucial substance of that Chinggisid tradition was the model of the warband, which was, often in hidden, submerged ways, implemented by most of the post-Chinggisid conquerors who carved out their own domains at the interface of the nomadic and sedentary worlds. Some of this enduring institutional legacy has been studied quite extensively — for the Timurids by Grupper and Maria Subtelny, for Iran by John Woods and Charles Melville. ${ }^{51}$ The current work will gratefully build on these pioneering endeavours and make further comparisons and connections between the keshik phenomenon within the various post-nomadic empires at the sedentary fringe of the Eurasian Arid Zone, including Russia, Islamic India, and the Middle East. The European, Middle Eastern, and Indian experiences of the ruler's personal guards will serve as a constant reminder of the more universal, non-nomadic characteristics of the warband as discussed in the final section of this chapter.

Taking the keshik as a starting point, we will particularly focus on the way its martial spirit was extended from the inner circle of the warband towards the military organization and military culture of the post-nomadic empires as a whole. This will necessarily involve a discussion of the transition of the warband into the imperial army and its relationship with the imperial bureaucracy. One way or the other, all these cases will address the central questions of this book as a whole: what held these people together, and what made them willing to fit into the larger political structure of the empire?

This brings us back to Ibn Khaldun and what he observed as the three main ingredients of 'asabiyya: pedigree (ansab), religious devotion (din), and military slavery (mawali; mamalik). ${ }^{52}$ In all three cases, these elements should be understood in their widest connotations, whether it produces real or imagined

\footnotetext{
50 Grupper, 'A Barulas Family Narrative', 45-46.

51 See also the pertinent comments by Michal Biran, "The Mongol Transformation: From the Steppe to Eurasian Empire', Medieval Encounters 10 (2004) 339-361.

$5^{2}$ Based on a less well-known part (i.e. beyond the Muqaddima) of his Kitāb al-Tbar as
} 
feelings of belonging, whether it takes an orthodox (e.g. jihad) or a heterodox (e.g. ghulluw) form, and whether it relates to the army or to the martial culture in the society as a whole. In addition to Ibn Khaldun's three components, a fourth ingredient, that of material rewards, from loot to cash salaries, should be added. As indicated in the quote opening this chapter, Ibn Khaldun was more than eager to recognize the importance of the 'money and taxation' that paid for the warband. Indeed, it once again demonstrates the fact that the pre-modern Chinese, Indian, Russian, and Ottoman empires surrounding Central Eurasia did not originate from either the nomadic or the sedentary world but were very much the result of the unescapable interaction and transition between the two.

Last but not least, we should take into account the possibility that Ibn Khaldun was altogether wrong about 'asabiyya. This is suggested by the South Asian experience so eloquently expressed by the late Indologist Jan Heesterman, who stresses that it was not the desert but sedentary agriculture that enabled the construction of extensive networks of kin and marriage, often using genealogical formulas to express the repartitioning of rights in the soil and its produce. By contrast, the cohesion of nomadic groups depends on immediate, albeit momentary, success and easily breaks down in case of failure. Hence, the nomadic warband lacks, as a basic principle, primordial ties that persist over time. It is equally understandable that the nomadic warband is likely to look for patronage and leadership outside its own ranks, with a settled magnate, who has a better chance of leading them to success and supporting them in case of failure-in other words, of providing the continuity (read 'asabiyya) - the warband lacks on its own. ${ }^{53}$

A similar conclusion is suggested by the recent work of Ali Anooshahr, who has demonstrated that Ibn Khaldun was just one-and the most systematicof a series of historians-Baihaqi and Nizam al-Mulk to name two otherswho endowed the history of Islamic dynasties with a universal, tripartite, cyclical quality, each embodied by an idealized monarch. ${ }^{54}$ In the first stage, we find

analysed and translated by David Ayalon, 'Mamlūkiyyāt', Jerusalem Studies in Arabic and Islam 2 (1980) 321-349.

53 J.C. Heesterman, 'Warrior, Peasant and Brahmin', Modern Asian Studies 29, no. 3 (1995) 644.

54 Ali Anooshahr, The Ghazi Sultans and the Frontiers of Islam: A Comparative Study of the Late Medieval and Early Modern Periods (London, 20o9) 13, 44; Ali Anooshahr, 'Mughals, Mongols, and Mongrels: The Challenge of Aristocracy and the Rise of the Mughal State in the Tarikh-i Rashidi', Journal of Early Modern History 18, no. 6 (2014) 559-577; Ali Anooshahr, 'The Rise of the Safavids According to their Old Veterans: Amini Haravi's Futuhat-e Shahi', Iranian Studies 48, no. 2 (2014) 249-267. 
the simple and austere ghazi leading a life of vagabondage with his brothers in arms. The second stage involves the climax of the dynasty, represented by a righteous king who rules over a prosperous and orderly realm. In the third stage, decline sets in because of a debauched and ineffectual ruler, who, through mismanagement, loses his throne to a different warband of fierce ghazis who are endowed with a high level of group cohesion. All this suggests that the work of Ibn Khaldun and his colleagues should be read not only as historical analysis, but also, and perhaps more importantly, as a literary model of a programmatic nature. Their chronicles are less about what happened in the past than prescriptive texts that provide a programme for the present and the future. In other words, they don't tell us how rulers actually behaved but how they should behave in order to avoid, as long as possible, the inevitable final stage, that of moral decline and foreign conquest. In this scenario, it should not be a surprise that every late-dynastic ruler was keen to demonstrate that he had not yet entered the third stage or that, by presenting himself as a ghazi, he had actually opened a new dynastic cycle.

From this perspective, Ibn Khaldun's notion of 'asabiyya should be perceived as a rather romantic post-conquest rationalization of the early period of empire. In fact, looking at various important examples, it appears that group cohesion on the basis of pedigree, devotion, or slavery was rather weak and never unchallenged. It was only after a conquest that sedentary administrators made 'asabiyya into a sophisticated tool to forge new bonds of loyalty between the ruler and his former warband. To turn the latter into an effective imperial army, the ranks of the warband had to be opened up to outsiders on the basis of a new ideological model. For someone like the sixteenth-century Ottoman historian Mustafa 'Ali it was no more and no less than divine favour that made for a successful ruler or sahib-izuhur, i.e. 'the manifest one'. Indeed, unconsciously echoing Thomas Aquinas's famous words 'if justice is taken away, what are kingdoms but robberies', he considered the main difference between a bandit and a legitimate ruler purely a matter of chronology: once a sahib-i zuhur had established a legitimate dynasty, his successors ruled by right of heredity. ${ }^{55}$ One can almost hear Chinggis Khan's affirmative 'yeah'.

With Mustafa 'Ali, also modern historians increasingly start to doubt the traditional narrative of the first imperial stage. As we have seen already, Chinggis Khan started to stress the kinship ingredient of his extended keshik only after his first conquests. In a recent monograph David Sneath convincingly 
dismisses the idea of tribe and kinship as the most important ingredient of cohesion among Central Asian groups, even before Chinggis Khan. ${ }^{56}$ MunkhErdene elaborates on this and cites Thomas Allsen, who had previously stressed that the use of kinship rhetoric was 'designed to enhance political unity, not authentic descriptions of biological relationship., ${ }^{57}$ Before this, Colin Imber strongly argued against the so-called ghazi thesis to explain the early rise of the Ottomans. Others, like Lindner, had already questioned the ideological content of the ghazi narrative and instead stressed a much more pragmatic meaning, that of a phenomenon that was basically geared towards the making and redistribution of spoils. ${ }^{58}$ After dealing with the Ottomans and Mughals, Anooshahr is now attempting to show that the earliest Safavid warband was forged less by the religious devotion of its members to an extraordinarily charismatic leader than the fact that it simply made the best of specific historical circumstances and good fortune. ${ }^{59}$

Where, then, does all this leave Ibn Khaldun's 'asabiyya as an analytical framework? What does this imply for the idea of nomadic cycles? What if chronicles do not so much describe but make history? My provisional answer would be that nomadic cycles do still exist but that these cannot be explained by 'asabiyya, as this was an ex-post-facto rationalization of more random historical circumstances. Hence, rather than the various elements of group cohesion, it is horse-based military superiority that accounts for the recurrent nomadic conquests. At the same time, historians should read chronicles as instruments of fashioning and disciplining both the ruler himself and his following. As chronicles tend to represent the administrators' points of view, their contents are less about the emergence of empire than about its continuation. In other words, most chronicles reflect Ibn Khaldun's second imperial stage after the divergence between the people of the sword and the people of pen, and thus they increasingly represent the latter's highly polished views on the former. As a consequence, bonds of kinship, devotion, and military slavery should be studied as post-conquest, sedentary alternatives to the nomadic warband. Although each of these would deserve at least a separate monograph, in this chapter they

56 David Sneath, The Headless State: Aristocratic Orders, Kinship Society, and Misrepresentations of Nomadic Inner Asia (New York, 2007).

57 Munkh-Erdene, 'Where did the Mongol Empire come from?', 221.

$5^{8}$ Colin Imber, 'The Ottoman Dynastic Myth', Turcica 19 (1987) 7-28; R.P. Lindner, Nomads and Ottomans in Medieval Anatolia (Bloomington IN, 1983). For the Ottoman discussion on the ghazi thesis, see Cemal Kafadar, Between Two Worlds: The Construction of the Ottoman State (Berkeley, 1994).

59 Ali Anooshahr, 'The Rise of the Safavids'. 
will only feature in the background of what should be considered its main topic: the specific case of the nomadic warband in the making of empires.

Finally, we may ask ourselves whether the present exercise does not repeat Ibn Khaldun's mistake of making too much of the nomadic warband as a specific case that dominates all other vectors of empire formation, even in the Arid Zone? Should we not distance ourselves from the emic, cultural point of view by looking at the day-to-day practice of imperial rule? Indeed, one may wonder, to what extent the practice of nomadic conquest really differs from that of sedentary conquest? Perhaps it is too early to answer these questions, but for the moment it is imperative to briefly recapitulate the nomadic warband's specific ingredients. First of all, following the late Marshall Hodgson, I would like to stress the fact that the sheer scale of their operations enabled the Mongols to conceive of their whole society as a single military force. Consequently, the civilian bureaucracy tended to be absorbed, as to rank and form of remuneration, into the military. ${ }^{60}$ Even the religious sphere, mostly in eclectic shamanistic forms, was part and parcel of the nomadic warband and subordinate to its charismatic ruler. ${ }^{61}$ Secondly, the society as a whole was reshuffled into movable and adjustable warbands that often acquired new ethnic labels. Here I would argue with Thomas Allsen that 'the Chinggisids seized Central and West Asia with the human resources of East Asia and then expanded and secured their holdings in the east with personnel transported from western Eurasia, many of whom later formed ethnic-based guard units'. ${ }^{62}$ These large, highly flexible military units literally expanded on the idea of the much smaller keshik or comitatus. Not the warband as such, but its unique capacity to organize and incorporate very large segments of the society was bound to the particular circumstances of the Arid Zone, especially at its fringes where it could tap into the considerable resources of much more wealthy sedentary societies, like those of China and India. These were to be exploited in the usual nomadic way: through collective 'tribal' appanages. As we will see, after conquering an area, the proximity of the Arid Zone meant that nomadic warbands were able to continue their normal ways of existence in a tense modus vivendi with sedentary, standing armies that drew their revenues more directly from land allocations under

\footnotetext{
6o Marshall G.S. Hodgson, The Venture of Islam: Conscience and History in a World Civilization, Vol. 2: The Expansion of Islam in the Middle Periods (Chicago and London, 1974) 406-409.

61 This continued into post-nomadic situations, such as that of the Qing as discussed by Peter Rietbergen in this volume.

62 Thomas T. Allsen, 'Population Movements in Mongol Eurasia', in: Reuven Amitai and Michal Biran, eds., Nomads as Agents of Cultural Change: The Mongols and their Eurasian Predecessors (Honolulu, 2015) 124.
} 
their control. ${ }^{63}$ Keeping all these considerations in mind, let us now discuss our four case studies of nomadic imperial state-formation, beginning with the most successful and powerful by far.

\section{China: From Jurchens to Qing}

\subsection{Jurchens: Keshik and Mukun}

Travellers who journeyed eastwards along the Silk Road usually, at some point, turned southward and headed for the wonders and riches of China. If, however, that temptation was ignored and the eastern trail continued to be followed, one arrived in an area that is now called Manchuria, and which extends into Korea. The people of this area occupied themselves either with hunting and fishing in the forests or with raising cattle and agricultural work in the plains. Although oxen dominated their own mixed economy, they exported huge numbers of horses to China. Sitting on the edge of the exchange between the desert and agricultural lands, the Jurchen inhabitants of Manchuria proved ideal commercial and political intermediaries between the Mongols and Chinese. ${ }^{64}$ In fact, this intermediate position gave them more political agency in Chinese history than any of the purely nomadic people of the steppes, including Chinggis Khan and his Mongols. In the last millennium, Manchuria gave birth to three imperial dynasties that ruled either northern China, as in the case of the Khitan-Liao (907-1125) and the Jurchen-Jin (1126-1234), or China as a whole, in the case of the Manchu-Qing (1644-1911). ${ }^{65}$

63 Reuven Amitai, 'Armies and their Economic Basis in Iran and the Surrounding Lands, c. 1000-150o', in: David O. Morgan and Anthony Reid, eds., The New Cambridge History of Islam, Vol. 3: The Eastern Islamic World, Eleventh to Eighteenth Century (Cambridge, 2000) 539-56o.

64 Here one could add Korea, which was heavily influenced by Mongol institutions; see David M. Robinson, Empire's Twilight: Northeast Asia under the Mongols (Cambridge Mass., 2009); Remco E. Breuker, 'And now, Your Highness, we'll discuss the Location of your Hidden Rebel Base: Guerillas, Rebels and Mongols in Medieval Korea', Journal of Asian History 46, no. 1 (2012) 59-95.

65 Ch'i-ch'ing Hsiao, The Military Establishment of the Yuan Dynasty (Cambridge Mass., 1978); Herbert Franke, 'The Chin Dynasty', in: Herbert Franke and Denis Twitchett, eds., The Cambridge History of China, Volume 6: Alien Empires and Border States, 907-1368 (Cambridge, 1994) 215-320; Igor De Rachewiltz, 'Personnel and Personalities in North China in the Early Mongol Period', Journal of the Economic and Social History of the Orient 9 (1966) 88-144; Thomas Allsen, 'The Rise of the Mongolian Empire and Mongolian Rule in North China', 
Returning to Chinggis Khan's Mongols, their expertise was in conquest. For sustaining their conquests, however, they turned to the example of the Jin dynasty, which gave them the institutional tools to establish a dynasty that ruled the whole of China under the name of Yuan (1271-1368). As we have stressed in the introduction, the key concept by which Chinggis Khan was able to bridge the gap between his Mongol past and Chinese future was his personal warband or keshik. Although we should acknowledge that the keshik as such was nothing extraordinary at the time, the main challenge was to stretch its size in such a way that it could incorporate new groups without undermining its overall cohesion, which was based on personal loyalty and intimacy. Since not all new manpower could be accommodated in the imperial warband, other subsidiary warbands were engineered from a wide variety of ethnic groups, of which only the leaders were represented in the imperial warband, while their sons became hostages and their daughters became spouses. Although Chinggis Khan and his successors exploited the warband's potential to its maximum and without precedent, they only succeeded because they could stand on the shoulders of their immediate, more 'cooked' predecessors: the Jurchen-Jin.

To expand on this point, we should first of all take account of the fact that Chinggis Khan's Mongol tribe had been tributary to the Jurchens. Chinggis himself had the Jin honorary title of 'chief of hundred'. Being very close to the imperial experience of the Jin, Chinggis Khan must have learned from the way the former had used the Jurchen institution of the mukun. Although dictionaries give definitions of this term that vary from clan to family, village, herd, and tribe, its political meaning at that time comes very close to that of household, but in the context of conquest and rule, even closer to that of the warband, and in many respects it was a precursor of the Manchu Banner (niru) system. In fact, the Jin had used the pre-existing idea of the mukun to set up a socio-military organization called meng-an mou-ke. Although the word mou$k e$ derives from mukun, it also had the politico-military meaning of 'the leader of one hundred men'. The word meng-an derives directly from Manchu minggan and means thousand. Hence we have something that seems very old and Central Asian and yet also very close to Chinggis Khan's famous decimal military system. Indeed, although the meng-an mou-ke system originally served as a comprehensive socio-political system that organized the entire Jurchen population under Emperor Aguda (r. 1115-1123), it soon was extended to become the most important military and political means of control over all subjugated

in: Herbert Franke and Denis Twitchett, eds., The Cambridge History of China, Volume 6: Alien Empires and Border States, 907-1368 (Cambridge, 1994) 321-414. 
peoples. Although the term suggests kinship, fixed hierarchy, and numbers, the reality was much more flexible and in fact was fundamentally similar to Chinggis Khan's conscripted warband in its most extended, post-conquest form. For example, we know from the Secret History that Chinggis Khan created ninetyfive mingghan (Mongolian for minggan) from the greatly enlarged manpower pool available to him in $1205^{-1206.66}$

Going into even greater detail, the mukuns consisted of a mixture of households and included their slaves and cattle. The numbers indicated neither exact amounts nor a fixed hierarchy beyond the fact that several pu-li-yan (unit of fifty) formed a mou-ke, several mou-ke formed a meng-an, and several mengan formed a wanhu, literally a unit of 'ten thousand households'. It is crucial in order to understand the meng-an mou-ke system as a controlling institution to highlight that the Jin emperor had his own personal mou-ke recruited from the other units, which constituted his own imperial guard. This organizational system was retained under the Yuan dynasty, and each was considered a self-sufficient socio-economic community that either managed or worked their own territories as a kind of appanage, and which only later developed into a much less flexible, land-based system of hereditary military households.

Coming to the Yuan, we have already seen that under Chinggis Khan the keshik not only served as an imperial guard, but had a wide range of functions including being an imperial domestic service bureau, a hostage camp, and an academy for young leaders; in many ways it was thus a rudimentary imperial administration. ${ }^{67}$ In due course, Chinggis Khan's nökörs obtained hereditary commands under the generic name of noyan (plural: noyad). Their titles were conferred by direct investiture or patent (yarlik), and they received a tablet as a token of authority, as well as expensive gowns in order to create and strengthen a sense of corporate identity. When a nökör who served in Chinggis Khan's keshik joined Chinggis with his household, he was actually bestowed with a household of his own. It was not uncommon for Chinggis to allow old tribal allies to keep their own ethnically homogenous group, with all their dependants, to confirm its chief as noyan after a summary census, and to turn it into a mingghan. ${ }^{68}$ More generally, though, original households were regrouped and given a uniform, if rudimentary, military skeleton. As such, those qualified were either organized into new units with Mongols or northern Chinese as their officers, or were distributed among original Yuan contingents. At the very heart of

\footnotetext{
66 Allsen, 'The Rise of the Mongolian Empire', 345.

67 Hsiao, The Military Establishment, 34; this section builds thoroughly on idem, 9-50.

68 Allsen, 'The Rise of the Mongolian Empire', 347.
} 
the organization, nökör were appointed as so-called darughas, or seal-bearers, to oversee other parts of the nascent imperial organization.

All this does not mean that the traditional consanguineous principle of 'tribal' organization was totally disregarded, but ethnic labels were of a more nominal character and, as later in the case of the Manchu Banners, stimulated the start of a new process of ethno-genesis. In this way, the chiliarchy became the basic political unit and the cradle of officialdom under the Jin, Mongol, and Yuan empires, with the keshik at its centre and as the most privileged group. In due course, though, when the empire expanded further south and had to incorporate more and more Chinese allies, the keshik was outnumbered by the imperial guards and other Chinese units originating from the south. Hence, several decades after the conquest, it became very apparent that the extended warband, so typical of and well suited to the Middle Zone, would reach its natural limits in the Outer Zone of sedentary China. Hence, soon after a conquest, there were increasing pressures to transform the Jurchen and Mongol warband organization into a Chinese administrative system along the lines of the proven Confucian ideas of wen. ${ }^{69}$ For the conquering elites, this shifting from the Mongolian custom or yasa could be easily translated into traditional Sinic notions of losing martial strength $(w u)$ and dynastic decline. Marco Polo, who stayed in China between 1275 and 1292, observed something similar:

Now they are much debased and have forsaken some of their customs, for those who frequent Catai keep themselves very greatly to the ways and to the manners and to the customs of idolaters of those regions and have very much left their law. ${ }^{70}$

Interestingly, though, the notion of a Chinggisid kind of keshik even continued under the non-nomadic Ming dynasty (1368-1644). ${ }^{71}$ Like their near contemporary Safavid colleagues in Iran, the emergence of Zhu Yuanzhang was based on

69 For the Jin, see Jing-shen Tao, 'The Influence of Jurchen Rule on Chinese Political Institutions', The Journal of Asian Studies 30 (1970) 121-130; for the Yuan, see John W. Dardess, Conquerors and Confucians: Aspects of Political Change in Late Yüan China (New York and London, 1973) 7-31, and Gunther Mangold, 'Das Militärwesen in China unter der Mongolen-Herrschaft' (PhD dissertation, Ludwig-Maximilians Universität, Munich, 1971).

$70 \quad$ Hsiao, The Military Establishment, 31.

71 David M. Robinson, 'The Ming Court and the Legacy of the Yuan Mongols', in: David M. Robinson, ed., Culture, Courtiers, and Competition: The Ming Court (1368-1644) (Cambridge Mass., 2008) 393-396. 
millenarian religious fervour that gave the conquering group its initial cohesion. ${ }^{72}$ Despite his celestial name of Hongwu, i.e. 'vastly martial', Zhu's early warband never attained the nomadic strength of its Jin and Yuan predecessors. From the very beginning, the early Ming rulers focused much of their efforts on limiting and controlling the power of military leaders and institutions. ${ }^{73}$ Much sooner and to a greater extent than in the case of their nomadic predecessors, the Ming military became increasingly managed by civilian officers. Although Mongols and Jurchens continued to provide manpower to the various imperial guard units, the Ming keshik became more aloof from the outside world and as such could not play its earlier, post-nomadic role of incorporating new groups. Hence, its social status decreased and its function became focused purely on the military, and particularly the internal security of the empire. Instead of the nökörs, the important linkages between court, military, and bureaucracy, as well as between the centre and the provinces, including its military households, increasingly became the domain of a new elite corps of eunuchs who served both as military commanders and administrative supervisors. ${ }^{74}$ According to the official Ming chronicle, the Ming-shih:

The eunuchs in the Ming period were sent out in charge of military expeditions, to supervise the army and the garrisons. They spied on the officials and the people, and secretly controlled all great authority. All this began in Yung-lo's reign [r. 1403-1424].75

By the end of the Ming dynasty, what existed of the central military arm was largely in the hands of eunuchs. ${ }^{76}$ The remarkable military renaissance under the Wanli emperor (r. 1573-1620) was an attempt to give the empire a new lease on life without recourse to $w u$, seeking strength instead in the neo-Confucian wisdom of a new generation of military commanders like Wang Yangming and

72 John W. Dardess, 'The Transformations of Messianic Revolt and the Founding of the Ming Dynasty', The Journal of Asian Studies 29 (1970) 539-558. I assume that the fact that both the Ming 'Red Turbans' and the Safavid Qizilbash wore red headgear is mere coincidence. Kai Filipiak, 'The Effects of Civil Officials handling Military Affairs in Ming Times', Ming Studies 66 (2002) 1-15.

74 Frederic Mote, 'The Ch'eng-hua and Hung-chih Reigns, 1465-1505', in: Denis Twitchett and Frederic Mote, eds., The Cambridge History of China, Volume 7: The Ming Dynasty, 13681644: Part 1 (Cambridge, 1988) 370-377; Robert B. Crawford, 'Eunuch Power in the Ming Dynasty', T'oung Pao 49 (1961) 115-148.

75 Crawford, 'Eunuch Power', 126.

$7^{6}$ On the role of eunuchs more generally, see Duindam, chapter 2 in this volume. 
Qi Jiguang, who could combine the ideals of wen and wu by increasing the personal discipline of their soldiers. ${ }^{77}$

\subsection{Manchu Banners}

After the Ming, both the later Jurchens (the Manchus) under the Later Jin (16161636), and the Qing dynasties (1636-1911) reintroduced the Jurchen mukun as their prime organizational unit and the fundamental criterion of Manchu identity. ${ }^{78}$ Meanwhile, the idea of an imperial keshik lived on in the imperial clan of the so-called Aisin Gioro, which was, however-and much more than the earlier mukun - based on 'real' ancestry consisting primarily of the descendants of the de facto Qing founder Nurhaci (r. 1616-1626) through the main and collateral patrilineal lines, and which were traced back to his grandfather Giocangga. The only exceptions were the so-called Princes of the Iron Cap, non-kinsmen who had rendered extraordinary service to Nurhaci and his son and successor Hong Taiji (r. 1626-1643). There was also the Imperial Guard, which consisted primarily of Manchus taken from the Banners, but, as in the case of the Ming, its function was limited and did not extend beyond protecting the emperor. ${ }^{79}$

Although the situation of keshik and guard under the Manchus was closer to Ming than to Jurchen antecedents, the warband system was actually reinvigorated through the re-introduction of mukuns in the new form of Banners. Indeed, in principle, a Banner was not that different from the earlier mengan under the Jin and Yuan. Indeed, like the meng-an, a Banner was much more than a military unit; it was a social formation and a political structure that encompassed peoples of many different backgrounds. Membership was based on patrilineal inheritance, marriage, or adoption. According to the main authority on the topic, Mark Elliott, we should not regard the Banners solely as an army, but rather as a sub-order of society that was defined primarily, but not exclusively, by an inherited duty to furnish professional soldiers of unimpeachable devotion to the dynasty, which in exchange supported the entire population registered in Banners (about two million in 1644), both materially and morally, through money, food, and housing, as well as privileged access to power, for their entire lives. Interestingly, the Manchu banners survived much longer than the Jin and Yuan meng-ans, partly because the Qing themselves

77 Filipiak, 'The Effects', 1-15. See also the forthcoming PhD thesis of Barend Noordam, Leiden University.

78 Pamela Kyle Crossley, The Manchus (Oxford, 1997) 28-29.

79 Mark C. Elliott, The Manchu Way: The Eight Banners and Ethnic Identity in Late Imperial China (Stanford, 2001) 79-81. 
lasted longer, and partly because the Qing decided to segregate the Banners from their Chinese surroundings while, at the same time, upholding their connections with its recruiting grounds in the north.

Following the precedents of other Central Asian conquerors like Aguda and Chinggis Khan, the Banner system was introduced by the new Manchu leaders Nurhaci and Hong Taiji at the very start of their conquest. They also imposed the new ethnonym of Manchu on their Jurchen followers as it became organized into the first Eight Banners. Although the Banner system started as an exclusively Jurchen organization, it included Mongols as early as the rule of Nurhaci, who were at first still redistributed under the Manchu Banners. In 1635, when Mongol forces had grown to number around ten thousand, Hong Taiji decided to remove the Mongol companies from the Manchu Banners and establish eight separate Mongol Banners, containing a total of eighty companies. Some Mongol units, however, were still incorporated into the Manchu Banners. The new Mongol Banners remained subject to the Manchu colour Banner chiefs of which they were a part, and in the years 1637-1642 this procedure was repeated for the Chinese (Hanjun) troops, creating a triple system of Eight Banners:

Each banner is divided into three sections. The tribes that were originally Nurhaci's ... make up the Manchu [section]. The various bow-drawing peoples from the Northern Desert ... form the Mongol [section], while the descendants of the people of Liao[dong], former Ming commanders and emissaries, those from the other dynasty who defected with multitudes [of soldiers], and captives are separately attached to the Hanjun. ${ }^{80}$

Despite the labels, ethnicity was never crucial in determining loyalty. As one popular saying had it: 'Never mind who is Manchu and who is Han, but ask who is a Bannerman and who is a civilian:' ${ }^{81}$ Nevertheless, as mentioned previously, after the Banners developed into hereditary institutions there was room for new processes of ethno-genesis based on exclusive Banner membership, and as such the gap between the Chinese within and outside the Banners actually increased.

As explained by Edward McCord, one significant feature of the Qing military system was its careful elaboration of checks and balances, aimed at preventing

$80 \quad$ Mark C. Elliott, 'Ethnicity in the Qing Eight Banners', in: Pamela Kyle Crossley, Helen F. Siu and Donald S. Sutton, eds., Empire at the Margins: Culture, Ethnicity, and Frontier in Early Modern China (Berkeley, 2006) 45.

81 Elliott, 'Ethnicity in the Qing Eight Banners', 46. 
the concentration of military power in a manner that might present a threat to dynastic rule. Firstly, in addition to the Eight Banners, there was the Green Standard Army, a predominantly Han Chinese force that was more than 200 per cent bigger, housed in small garrisons scattered throughout the country and largely modelled on the military organization of the preceding Ming, in which the purely military chain of command overlapped with the civil administration and the supervisory powers of provincial governors. In a slightly different way, a similar overlap occurred in the internal structure of the Eight Banners; while each Banner had its own separate command structure and bureaucratic administration, the much less scattered Banner garrisons in the main administrative centres were formed not by one Banner but by a combination of forces taken from a number of different Banners. In major military campaigns, special expeditionary forces were formed by combining a number of different units from both Eight Banner and Green Standard Armies. Even under the Qing, the commanders of such campaigns were often appointed not from the officers of any of its component forces, but from the ranks of the civil bureaucracy. This again diluted the military in such a way as to hinder the accumulation of military power in the hands of any one official or military power. ${ }^{82}$

This balancing act was employed by each and every Eurasian dynasty. What makes the Qing Banner system unique is that it represents the continued existence of the warband under fully sedentary conditions. At the very start of its existence it served to incorporate and reshuffle important allied and conquered groups. At the same time, for almost three centuries the Banners helped to preserve the identity and virility of the conquering elites as a whole and provided a segregated pool of loyal personal nökörs who could be employed in both military and civilian capacities. As before, under the Jin and Yuan dynasties, this gave rise to a dual administration in which the official hierarchy of military commanders and civilian officers was permanently supervised by Bannermen as the emperor's personal agents. As argued elsewhere, the dual system was a typical post-nomadic variety of apartheid, not instigated by some 'modern' urgency to distinguish between ever more professional armies and ever more rational bureaucracies, but by the need of post-nomadic rulers to keep the cavalry core of the army as loyal, fit, and ready as possible. ${ }^{83}$ Since the Manchu military was as much as possible kept apart from the existing Chinese

82 Edward McCord, The Power of the Gun: The Emergence of Modern Chinese Warlordism (Berkeley, 1993) 20-22; based on Wu Wei-ping, 'The Development and Decline of the Eight Banners' (PhD dissertation, University of Pennsylvania, 1969).

83 Jos J.L. Gommans, 'Warhorse and Post-Nomadic Empire in Asia, c. 1000-180o', Journal of Global History 2 (2007) 1-21. 
bureaucracy, there was also no need to find complicated compromises that would actually undermine both sides of the system.

Nonetheless, even under the Qing rulers the system found its natural limit when administrative units based on different, often well-established, standards of recruitment began to take over while, at the same time, a centralized system of stipends on the basis of individual Banner service was introduced, which consequently moved away from a situation where garrison lands were collective appanages. Even the Qing could not avoid the increasing bureaucratization. As under the Ming, the Qing keshik became a more isolated and more exclusively military institution that was essentially geared towards internal security, once again giving rise to a now-familiar anxiety of imperial decline, which, according to the old elites, could be stopped only by reinvigorating the 'old ways' and cleaning up the ranks through purifying programmes of Manchuization, as was the case particularly during the long reign of the Qianlong emperor (r. 1735-1796). ${ }^{84}$ As we will see, the 'purifying' policies of this fourth official Qing emperor were quite similar in their bases to those of the fourth official Mughal emperor Aurangzeb (1658-1717); after one and a half centuries and three generations of dynastic rule, both emperors attempted to save their empires by stressing moral rearmament and a return to so-called fundamental values, Manchu ones for the former, Islamic for the latter. ${ }^{85}$ This remarkable dynastic parallel immediately evokes Ibn Khaldun and demands a closer look at what seems to be another intriguing case of his dynastic cycle.

\section{India: From Mongols to Mughals}

\subsection{Timurids: Keshik and Tümen}

Just like the Jurchens in Manchuria, the Afghans and Turks in Khorasan and Turkistan were ideally situated to serve as political and military brokers between the desert and cultivated lands. As in the case of Manchuria, control over these interstitial areas was the key to an Indian empire, as is demonstrated by the sequence of Indo-Turkish and Indo-Afghan sultanates in both Hindustan and the Deccan. Although it would certainly be worth comparing these Turkish and Afghan patterns of state-formation with those of the Jurchens, I will limit myself here to an investigation of the various Timurid states that were carved

\footnotetext{
84 Elliott, 'Ethnicity in the Qing Eight Banners', 27-58; Pamela Kyle Crossley, 'The Conquest Elite of the Ch'ing Empire', in: Willard J. Peterson, ed., The Cambridge History of China, Volume 9.1: The Ch'ing Empire to 1800 (Cambridge, 2002) 313-360.

85 See my 'Warhorse and Post-Nomadic Empire', 18.
} 
out along the various waystations connecting Turkestan and Khorasan in our Middle Zone to India in our Outer Zone. We will start with a discussion of Timur (r. 1370-1405) himself, and then move to his Bayqara and Mughal descendants, in Khorasan and Hindustan respectively.

Looking somewhat closer at the administrative practices in Timur's empire, we can observe a great deal of continuity with the Chinggisids. As far as the keshik is concerned, it seems that the institution continues, although the term itself disappears from the annals. If we look in greater detail, though, it seems that the so-called tümen comes quite close to exhibiting the classic features of the keshik, and very close to the Jurchen idea of the meng-an mou-ke system. As we have already seen in the introduction, under Chinggis Khan this was part of the decimal ranking system and referred to a military unit of 10,000. In principle, the tümen was not a tribal but a specifically engineered group with a mixed ethnic background whose leader was a trusted member of the Chinggisid keshik. In due course, many of these tümen leaders received appanages that were supposed to support the tümen. ${ }^{86}$ From these, tümen leaders were often able to gain territorial rights and develop extensive households of their own. As a result, a tümen began to signify both a household and territory. For example, Timur himself started his career as the hereditary amir-i tümen of Kesh. When he started to create his own empire, the relatives and other followers of his orginal tümen (read keshik) supplied the imperial leadership. Very much in line with the Chinggisid tradition, Timur divided his realm into four sections, each governed by the households of one of his sons but commanded by members of his followers' families. Each of his sons had a guardian (ateke) appointed to him in order to keep an eye on him. In principle the sons and their households were treated in the same way as the other leaders and their tümen. Timur regularly interfered in the make-up of the tümen by removing troops from the control of the traditional leaders and placing them under the command of his own intimates and early comrades-in-arms. Other control mechanisms included the rotation of guard services at court, taking relatives of leaders as hostages, and replacing tümen-leaders with other members of the same family. Another factor that is a clear reminder of those of the original keshik is Timur's policy of building entirely new tümen that were intimately attached to his own person through the use of labels such as khanabachagan- $i$ khass (personal children of the house) and bandagan-i khass wa muqarraban- $i$

86 To distribute large parts of conquered lands as appanages to large military households was a well-known practice under Mongol rule, although in principle all income from all districts had to be shared by all the participating groups. 
dargah (personal slaves and intimates of the court) which even suggests bonds of adopted kinship and slavery, notions that persisted into Akbar's period but which, as we will see, received a rather mixed reception in India.

Another important consequence of the success of Timur's tümen was that, one way or another, it had to accommodate the growing financial administration of the conquered territories. As in the case of earlier Mongol rule in China, this entailed the emergence of a new civilian branch of government focusing on administrative and financial matters. These responsibilities could not be managed by the classic keshik, as this consisted primarily of military and more intimate household posts like chamberlain (ichik-aqa), chief taster (bokavalbegi) or chief arms-bearer (qorchibashi), to name but a few. The challenge was to incorporate expert civilian elements to govern the freshly conquered territories without compromising the effectiveness of the warband. Hence, the new Persian-dominated financial department, or diwan-i ala, was kept detached from the administration of the primarily Turkish military department, which kept its own scribal organization, the diwan-i tovachi. In general, though, both divisions were still part of the ruler's warband and there were no rigid functional divisions; indeed, it was a conscious policy to maintain a certain vagueness of ranks and confusion of duties. Hence, as in the Mongol tradition, all officials remained generalists: scribes serving as commanders, commanders as scribes. ${ }^{87}$

Overall then, the imperial apparatus under Timur and his immediate successors differed little from that of the Chinggisids or that of the early Jin and Yuan. In fact, the basic idea of the keshik as a loyal military core consisting of relatives and personal followers continued to be manifested in the institution of the tümen, while the ruler's personal tümen was expanded to accommodate a new financial department. The leaders of the financial and military branches were also members of the ruler's household, and the ruler could control and manipulate his followers by awarding positions and honours such as amir, bahadur, tovachi (troop inspector) and darogha. These ranks indicate above all personal service to the ruler, often with no clear hierarchy and having a great deal of functional overlap. Indeed, the result of conquest was Ibn Khaldun's 'expected' divergence between pen and sword. However, the split was not allowed to be complete, and both branches continued to operate within the ruler's extended household (read keshik or tümen), which also incorporated the empire's other

87 For Timur's imperial organization, see Beatrice Forbes Manz, The Rise and Rule of Tamerlane (Cambridge, 1989) and her Power, Politics and Religion in Timurid Iran (Cambridge, 2007). 
tümen-leaders. Some newly created tümen were able to achieve a more intimate, personal relationship with the ruler and may have provided him with an inner army of intimates (khass) within the extended household. The correct functioning of this system depended on whether the ruler could collect sufficient revenues and was able to keep his own people on the move. Both were conceivable only under the (semi-) nomadic conditions of the mixed sedentary-nomadic frontier zones of Iran, Afghanistan, and Turkistan.

When Timur was succeeded by his son Shahrukh in 1409, the transition from a Turko-Mongolian nomadic empire of conquest to a Perso-Islamic sedentary empire based on agriculture continued. This was reflected in Shahrukh's decision to move the capital from Samarqand to Herat. He also officially proclaimed the abolition of Turko-Mongolian customs in favour of Islamic law. As in other Turko-Mongolian states in the region, highly educated Persians, who hailed from old provincial families, played a key role in developing the bureaucratic administration of the Timurids and in promoting agricultural values. The Bayqara Timurids of Herat tried to bridge the two worlds by patronizing a Timurid artistic renaissance that involved the promotion of the Chaghatai language and belles lettres.

It is important to stress, though, that as long as the Timurids remained in Khorasan, they were not able to set up a stable civil administration with a solid fiscal base. Although they tried to limit the random distribution of revenuefree lands (soyurghal) to the Timurid military elite, the latter continued to dominate the administration and precluded the rise of a more autonomous state bureaucracy. In the end, the Timurids had no choice but to invest in their capital and its immediate environment, trying to maximize agricultural production on the basis of intensified irrigation. For the Timurids, though, even urban splendour and agrarian success had its downside as it would inevitably undermine their martial capacities. At least, this was what the young Babur wrote when he saw his Herat-based uncles indulging so excessively in the pleasures of settled life: 'They were good at conversation, arranging parties, and in social manners, but they were strangers to soldiering (sipahiliq), strategy, equipment, bold fight and military encounter.'88

The same was true for most polities in the Middle Zone. Whether slightly earlier under the Ilkhanids (1256-1335), during the reign of Ghazan (12951304), or under their contemporaries the Qara Quyunlu (1375-1468) or the Aq Quyunlu (1378-1501), all attempts at administrative centralization and reform towards more bureaucratization suffered the same fate against a coalition of 
nomadic-military and religious elites. Of course, one way to make themselves less dependent on their nomadic following was to resort to military slaves as advocated by the Seljuq minister Nizam al-Mulk (1064-1095) and practised earlier not only by the Seljuqs, but also by the Samanids, Ghaznavids, and Ghurids in Afghanistan and the Mamluks in Egypt, all of whom mainly recruited Turkish slaves from Central Asia. ${ }^{89}$ It appears, though, that following ongoing Mongol and Turkmen immigration, the Khorasan-Iran region as a whole experienced a nomadic resurgence, which may have made this a less viable option than before, or indeed afterwards, as demonstrated by the re-introduction of slaves (ghulams) under the Safavids (1501-1735). ${ }^{90}$ As we will see later, the neighbouring Ottomans also turned to military slavery, but shifted the main recruiting grounds from Central Asia to Eastern Europe. Indeed, it seems that the increasing wealth of the sixteenth century created a new window of centralizing opportunities for Turko-Persian dynasties in general. ${ }^{91}$

Before turning to military slavery, the Safavids had successfully started to use religious devotion to instil loyalty in their primarily Turkish following, now restyled as Qizilbashes or 'Redheads', a term derived from their distinctive crimson headgear. In fact, it was this Sufism that had accompanied the process of Turkish migration, settlement, and state-formation in Iran. Under Turkish and Iranian influence there was an increasing convergence in the terminology of Sufism and kingship. All of a sudden, Sufi dervishes began to preface their names with titles appropriate to rulers such as mir and shah, while their shrines became called royal courts (sing. dargah) and their headgear considered crowns (sing. taj). ${ }^{92}$ Almost every fifteenth- and sixteenth-century polity

89 Woods, The Aqquyunlu, 14. On the hesitant implementation of Ilkhanate reforms, see Reuven Amitai, The Mongols in the Islamic Lands: Studies in the History of the Ilkhanate (London, 2007).

90 D.T. Potts, Nomadism in Iran: From Antiquity to the Modern Era (Oxford, 2014) 213. On this question, see also Ann K.S. Lambton, Continuity and Change in Medieval Persia: Aspects of Administrative Economic and Social History, 11th-14th Century (London, 1988). Despite the current revisionism that stresses Mongol agency in what seems to be an Iranian literary renaissance, the economic picture of the Mongol impact is still rather bleak.

91 See e.g. Liesbeth Geevers, 'Safavid Cousins on the Verge of Extinction: Dynastic Centralization in Central Asia and the Bahrami Collateral Line (1517-1593)', Journal of the Economic and Social History of the Orient 58, no. 3 (2015) 293-326.

92 Nile Green, Sufism: A Global History (Oxford, 2012) 99; see also John R. Perry, 'EthnoLinguistic Markers of the Turko-Mongol Military and Persian Bureaucratic Castes in Premodern Iran and India', in: Irene Schneider, ed., Militär und Staatlichkeit. Beiträge des Kolloquiums am 29. und 30.04.2002 Halle 2003. Orientwissenschaftliche Hefte 12; Mitteilungen 
in the Middle Zone between Anatolia and India became infused with Sufi ideas of love and devotion. Whether rulers looked for the spiritual support of dervishes or, as in the case of the Safavids, claimed spiritual leadership for themselves, Sufism offered a wonderful tool for transforming a nomadic warband into a religious one.

With this observation, we are back at the heart of Ibn Khaldun's theory and may, along with him, conclude that, at least throughout the Middle Zone, both military slavery and religious devotion were considered two very forceful sedentary alternatives to, or even antidotes against, the nomadic warband of the Chinggisid kind. As such, the Safavid model was eagerly embraced by the Mughal emperor Akbar in the idiosyncratic form of Din-i Ilahi and as a remedy against the autonomous and egalitarian tendencies of his original Timurid and Turkish followers. ${ }^{93}$ This brings us back to the later Timurids, better known as the Mughals, and it will be interesting to see to what extent the warband of its founder Babur was built on that of Timur and how it was transformed under his successors in India.

\subsection{Babur's Warband}

Much as Nurhaci would do around a century later in Manchuria, Babur started his Indian empire in 1504 in Afghanistan: areas at the transition between our Middle and Outer Zones. His career is the romantic story of a young prince who, despite many mishaps, rises from Central Asian rags to Indian riches. Looking at his early years as a wandering vagabond in Central Asia, one is immediately struck by the similarities with the early careers of his celebrated forebears. Well-versed in the history of his own ancestors, Babur himself must have been very much aware that his history was one that repeated many earlier histories of empire builders. The tripartite division of his autobiography into Mawarannahr (i.e. Transoxania), Kabul (i.e. Afghanistan) and Hind (i.e. India) neatly follows the literary transition from the upbeat cheerful spirit of vagabondage or qazaqliq, when still in the steppes of Central Asia, to the more detached, melancholic mood of exercising istiqbal (sovereignty) after conquering India. There can be no doubt that Babur himself knew exactly how

des SF B 586, 'Differenz und Integration' 5 , 119. On the development of Sufism in relationship with royalty, see also the works of Ahmet T. Karamustafa, God's Unruly Friends: Dervish Groups in the Islamic Later Middle Period 1200-1550 (Salt Lake City, 1994) and Jürgen Paul, 'Scheiche und Herrscher im Khanat Čag̉atay', Der Islam 67, no. 2 (1990) 278-321.

93 Jos Gommans, Mughal Warfare: Indian Frontiers and High Roads to Empire, 1500-1700 (London, 2002) 70-71. 
to frame his story. Of course, there was also the old Mongol custom or törä that, far from offering a fixed set of norms indicating that charisma (sölde), could be bestowed on anyone who proved his mettle on the battlefield. ${ }^{94}$ Indeed, people turned to törä in appreciation of military valour, often in compensation for kin or age that may have been lacking, as in the case of Babur, when it was said, that 'he is young in years, but he is great according to the törä because he has conquered Samarqand several times by dint of sword. ${ }^{95}$ For Babur, it was exactly this kind of military capacity that was missing among his settled and degenerate uncles in Herat, referred to above. Although he admired the carefree sociability of their court, he also despised the excessive fesq u fujur (immorality and debauchery), ${ }^{96}$ and he and his successors knew very well that if they were to survive as a political power, such dynastic decay had to be avoided at all costs.

Whatever one may think of its Chinggisid origins, Babur's early warband did not constitute the tightly controlled, highly disciplined inner circle or keshik along the lines of the Chinggisid model. ${ }^{97}$ In principle, though, its structure was quite similar. Like many Chinggisid khans or Timurid mirzas, Babur had a warband of his own consisting of both relatives (biradaran-u-khweshan; brothers and relations) and retainers (mulazaman/naukaran), who were linked to each other through marriage and companionship. The latter was sustained in recurrent social events ranging from hunts to drugs-and-drinking bouts. In the early days of Babur's wanderings, the warband came closest to its original meaning: a small band of freely recruited warriors without much functional differentiation within the group. Pace Ibn Khaldun's ideas about tribal 'asabiyya, and despite its small size, the cohesion of this group was never particularly strong as it depended entirely on the success of its leader. Without success, there were no spoils to be shared, and hence no reasons to be loyal.

94 For sölde and törö in the Central Asian context, see the important Russian contributions by Tatyana D. Skrynnikova, partly translated in: 'Sülde-The Basic Idea of the ChinggisKhan Cult', Acta Orientalia Academiae Hungaricae 46 (1992/3) 51-59; 'Power among Mongol Nomads of Chinggis Khan's Epoch', in: N.N. Kradin, D. Bondarenko, and T. Barfield, eds., Nomadic Pathways in Social Evolution (Moscow, 2003) 135-157; 'Die Bedeutung des Begriffes törö in der politischen Kultur der Mongolen im 17. Jahrhundert', Asiatische Studien 63 (2009) 435-476.

95 Gulbadan Begam, Humāyun-nāma, trans. W.M. Thackston (Costa Mesa, 20o9) fol. 5a.

96 Stephen F. Dale, The Garden of Eight Paradises: Bābur and the Culture of Empire in Central Asia, Afghanistan and India (1483-1530) (Leiden, 2004) 81, 167.

97 Dale, The Garden of Eight Paradises, 90. 
In due course, when moving to Kabul to carve out his own small kingdom, Babur's warband started to expand and we begin to detect a structure that comes fairly close to that of the early Timurids and also to that of the Jurchen idea of the mukun. First of all, Babur's warband incorporated the chiefs (beglar; Persian: umara') of allied warbands with their own following (jamiyat) of relatives and liegemen. Some of these begs were long-standing tribal leaders who had recently joined Babur as so-called Guest (mihman) Begs. Another preexisting group of some standing was the so-called Andijani Begs, who apparently originated from Babur's homeland. Others had climbed the inner ranks by starting as young trainees or ichkilar (Persian: jawanan) before Babur was willing to turn them into full begs, called ichki-beglar. Like the so-called Baburi begs, these were Babur's own creatures and as such were probably part of his naukari (from nökör) following. In addition, Babur created a new inner army or khașah tabin (Persian: tabin-i khasah) consisting of so-called yiqitlar: individual warriors without pedigree who had no following of their own. ${ }^{98}$ This guard corps comes very close to Timur's personal tümen, mentioned above. Moving from Samarqand to Kabul and Kabul to Delhi, the proportion of these trained servants would only increase. Not surprisingly, Babur's early Mongol allies, many of them of real or imagined Chinggisid descent, detested the growing importance of tarbiyat or 'training' against nasab or pedigree. Of course, they knew perfectly well that tarbiyat had always been a crucial ingredient of the Mongol warband, i.e. an important bond between a Mongol warlord and his retainers. What they deplored, though, was its further extension to actually replace Chinggisid lineage as the base of empire..$^{99}$ Overall, the structure of Babur's extended warband is similar to that of Timur. What seems missing, though, is a separate financial department. At this early stage of stateformation financial positions are still hidden behind the military façade of the warband.

\subsection{Mughal Mansab}

Turning to Babur's son, due to his ongoing campaigns Humayun (r. 15301556) was, like his father, hardly in a position to expand the warband into an imperial structure. What is new, however, is that he was quite able to design his God-given empire and construct its organization on the basis of some highly esoteric cosmological and alchemical reasoning as revealed in

98 A.R. Khan, 'Gradation of Nobility under Bābur', Islamic Culture 6o (1986) 79-88.

99 Ali Anooshahr, 'Mughals, Mongols, and Mongrels'. 
his dreams. ${ }^{100}$ In the Qanun-i Humayuni by Khwandamir, we find a whole range of original functional and hierarchical arrangements applied to the preexisting warband organization of his father. For example, in introducing a new alchemical hierarchy of twelve golden arrows (tir-i mutalla ${ }^{3}$ ), there are echoes of the warband's ranks, including the mentioning of the term ichkiyan. The term 'beg' is not used; instead, the word mansab (position, rank), a rather loose term that would become much more prominent and more rigidly codified under his son Akbar, was applied.

Indeed, despite the conquests of Timur, Babur, and Humayun, it was only the latter's son Akbar who managed to establish a settled empire on the Indian subcontinent, one which lasted for more than two and a half centuries. In contrast to their Qing counterpart in China, the Mughal warband seems to have evaporated almost immediately upon its arrival on the plains of Hindustan. Of course, we can see some kind of continuity in Babur's personal unit of the yikitlar in Akbar's standing army of a few thousand ahadis, who were equipped with several horses and had a reputation for being excellent archers. These gentlemen-at-arms, as the late William Moreland calls them, were single men (from ahad, one) who had no following of mounted retainers themselves. Apart from the ahadis, other household troops of the Mughals were composed of large number of ahsham: all sorts of rag-tag foot-retainers (piyadagan) comprising clerks, runners, gate-keepers, palace guards, couriers, swordsmen, wrestlers, slaves, palanquin bearers etc. These included infantrymen consisting of a few thousand musketeers (banduqchis) commanded by 'captains of ten' (mir-dahs). In addition, there was the important elephant unit, as well as the imperial stables for warhorses and pack animals. The artillery was also part of the imperial household, as was also the case in the Ottoman and Safavid armies. Last but not least, probably inspired by the Safavid example, Akbar decided to start a kind of imperial Sufi order of his own. This Din-i Ilahi was meant for those amirs whose devotional service to Akbar required them to give up their life (jan), property ( $m a l$ ), religion (din), and honour (namus) for which in return they received Akbar's seal and portrait. Although only a few amirs became actually disciples of Akbar, the general way of expressing one's loyalty and service to the emperor became very much influenced by the Sufi idiom of love and devotion, even in the emperor's absence seeking his proximity in their dreams. Although slavery already evoked the notion of religious devotion, for Akbar this was not enough:

100 A. Afzar Moin, The Millennial Sovereign:Sacred Kingship and Sainthood in Islam (New York, 2012). 
His Majesty, from religious motives, dislikes the name banda, or slave; for he believes that mastership belongs to no one but God. He therefore calls this class of men chelas, which Hindi term signifies a faithful disciple. ${ }^{101}$

Despite these chelas, what is strikingly missing in the household segment of the Mughal army is a substantial number of military slaves. Military slavery had been an important element during the early Delhi Sultanate but began to disappear again during the fourteenth century. Hence, the Mughal chelas should not be confused with the mamluk phenomenon of Ottoman Janissaries or Safavid ghulams. The chelas were only few in number and held no regular military functions. ${ }^{102}$

In numbers and weight, Akbar's inner army was dwarfed by the new mansabdari establishment, which was ideally suited to exploit the huge military labour market that was India. Akbar had introduced this new scheme, where hierarchy was established by means of ranks or mansabs, and it had become necessary because rank and remuneration had to be linked to a pre-existing revenue system based on the so-called iqta' (later, under the Mughals, called jagir), in which every holder of an iqta' had the right to collect the revenue of an assigned piece of land in exchange for certain military or administrative services. In principle, the idea was not connected to the equal distribution of large tracts of conquests, as had been the case under the tümen, but involved, in theory at least, conditional and temporary rights to accurately assessed revenue proceeds $\left(j a m a^{c}\right)$. Thus, by individualizing the exploitation and redistribution of the agrarian resources as controlled by local imperial officials, the iqta-system provided the ruler with a sophisticated system of top-down and bottom-up control. To make it work though, the army had to be accordingly organized to match the system. Hence, each military unit with a direct relationship to the ruler, from the great warlord to the individual horseman, received temporary rights to collect the revenues in a defined territory.

The mansabdari establishment was managed by a separate financial department that also administered the distribution of jagirs. Like the departments for the army and the revenue, the imperial household kept its own administration,

\footnotetext{
101 Abu l-Fazl, The A-in-I Akbari, trans. H. Blochmann and H.S. Jarrett, end revised edition by D.C. Phillott and J. Sarkar (New Delhi reprint 1989; first published 1927-1949) Vol. 1, 263264; Persian text, edited by H. Blochmann (Calcutta, 1872-1877) Vol. 1, 427-429. For an insightful recent study, see William R. Pinch, 'The Slave Guru: Masters, Commanders, and Disciples in Early Modern South Asia', in: Jacob Copeman and Aya Ikegame, eds., The Guru in South Asia: New Interdisciplinary Perspectives (London and New York, 2012) 64-80.

102 Gommans, Mughal Warfare, 49, 61, 83.
} 
which also managed the crown domain (khalisa). Although some functional overlap continued, a division of three separate elements had emerged: manzil (house), sipah (army), and mulk (land).

Tracing the location of our nomadic warband, it may still be seen in the ongoing role of the household to bring officers close to the emperor and to transform many of them into loyal sons of the house, or khanazadas. All major imperial officers were bestowed with a mansab by the emperor himself. Mansab had a dual capacity and represented both real military strength (i.e. the number of troops) and the emperor's personal favour. So on paper, one could still imagine mansabdars as 'begs' of their own subsidiary warbands. At court mansabdars rotated as guards, received all kinds of personal honours, and participated in elaborate rituals. All this symbolized their incorporation into the emperor's personal body politic. Although this may remind one of the inclusive characteristics of the erstwhile nomadic warband, its context, structure, and spirit had significantly changed. Much like the usual imperial guards in other sedentary empires such as that of the Ming and the Romanovs, the unit of the ahadis was a relatively isolated inner army that hardly interacted with the other imperial departments and did not serve as a training ground for the mansabdars. The latter increasingly operated as autonomous landlords (zamindars) and war-jobbers in an increasingly commercialized military labour market. The divergence between pen and sword was no longer contained within the warband but covered the entire empire and operated in accordance under its own sets of rules. With the further expansion of the empire the manzil increasingly lost its hold on both sipah and mulk.

The later emperor Aurangzeb (r. 1658-1707), often considered the last of the 'Great Mughals', was rightly alarmed about this situation and consciously attempted to increase the crown domain at the cost of the jagirdari establishment. In the late seventeenth century, this triggered the so-called jagirdari crisis, giving rise to the failed incorporation of the Maratha gentry into the imperial system, which, for the first time, signalled that the empire had finally reached its limits. As previously mentioned, Aurangzeb's move towards the 'old ways' of Islam compares quite nicely with similar 'rescue missions' under the later Qing to counter an analogous 'bloating' of the ranks. ${ }^{103}$ In both cases, this kind of imperial midlife crisis was typical for a (semi-) nomadic warband that had crossed over into a prosperous sedentary empire.

103 Terms taken from Elliott, Manchu Way, 306, 351 


\section{Russia: From Tatars to Cossacks}

\subsection{Muscovy: Dvor and Boyars}

Russian historiography was dominated for a very long time by Marxist historians for whom class was the most important analytical category. In the past two decades, however, the situation has radically changed, and there is now more room for other interpretations of Russian history. What remains, however, is the debate about whether it is part of European or Asian history. Another aspect of this debate is the question of continuity and change. Most contemporary historians of Russia stress the Byzantine legacy and see an internal continuity between Kievan and Muscovite institutions, which should be studied in connection and comparison with the West (e.g. Rüss). Within this debate there is ongoing discussion about Russia's famous autocracy: did it really result in Europe's weakest aristocracy or, as is the viewpoint of recent revisionism, was it merely a façade to cover up a general consensus among the elites (e.g. Kollmann)? A further, neglected part of this discussion is the work, both older and more recent, of historians that stresses a major historical break, and a consequent change, as a result of Russia's entanglements with the Mongols and Tatars (e.g. Ostrowski). Here, the debate focuses on whether or not certain Russian institutions such as the duma or the zemskii sobor are European, Mongolian, or more indigenous phenomena. ${ }^{104}$ This rather essentialist discussion could indeed gain from the notion of 'façade', which has already proven its usefulness when dealing with Russia's autocracy. Here it may be useful to be reminded of Korea's submission to the Mongols, which was all about outward appearance when, to gain Mongol acceptance and forestall more onerous demands for material and manpower, King Ch'ungnyŏl (r. 1298-1308) of Koryŏ donned Mongol garb, cut his hair in the Mongol fashion, and acquiesced to Mongol demands to rename the Koryŏ administrative bureaux to reflect their subordinate status within the empire. ${ }^{105}$

As a non-specialist and relative outsider to Russian historiography, I can but highlight some important contrasts with other regions. Firstly, in comparison

104 See Ostrowski, Muscovy and the Mongols. Ostrowski builds on the earlier work of George Vernadsky and Charles Halperin (going back to the founder of the Eurasian school, Prince E. Trubetskoi). The latter, though, raised doubts about Ostrowski's major conclusion; see Charles J. Halperin, 'Muscovite Political Institutions in the 14th Century' and Ostrowski's response in 'Muscovite Adaptation of Steppe Political Institutions: A Reply to Halperin's Objections', Kritika: Explorations in Russian and Eurasian History 1 (2000) 237-257; 267304.

105 Robinson, Empire's Twilight, 59. 
with China and India, the economic conditions of Muscovy before Peter the Great remained extremely poor. Even after Muscovy had 'gathered' the other Russian lands (Novgorod, Tver, and Ryazan) under its fold, funds, whether by taxing or plundering the population, were still insufficient to support a more substantial court (dvor), officially based in Moscow, but which for purely logistical reasons continued to lead a peripatetic existence. Due to the limited surpluses provided by Russia's poor forest land, it was not only the court that could hardly survive, but the aristocracy with hereditary estates (votchina) also found it hard to take root and build strong local power centres, the more so because of the practice of divisible inheritance, which led to the multiplication of title-holders and the ongoing division, and consequent reduction in size, of estates between siblings. The lack of hereditary titles associated with posts, or of hereditary posts of any kind, also considerably weakened the aristocracy and impeded its consolidation into an autonomous political group as was the case in Western Europe. Although in practice men became boyars because they were born into hereditary boyar families and lived to inherit that rank at court, in principle the title was not hereditary as only the family might inherit a claim to be promoted to that rank. ${ }^{106}$ Seeking alternative sources of income, these boyars depended, more than any other contemporary aristocracy in Eurasia, on imperial service. But since the court itself lacked funding, it could not pay a standing cavalry army of boyars and so service was paid by service land or pomestia. As in the case of the Mughal jagir, pomest'ia was not regarded as the private property of the pomishchik, but it provided the fixed income for his maintenance and equipment, and he was not expected to concern himself with its exploitation. According to Isabel de Madariaga, 'he was not therefore a landowner in the Western sense of the word, but a land user entitled to a certain income from the land. ${ }^{107}$ Interestingly, as in the case of the Mughal mansab, pomest'ia was linked to an elaborate ranking system called mestnichestvo, a code of precedence that registered ranks of service. As a result, the service elites as a whole, originally of mixed social origins, were gradually sorted into those (a) who served the Grand Prince directly, as members of the $d v o r$, received pomestia, and were merged into the dvoriane, or future servicemen, and (b) those who had served local princes and boyars and continued to carry out their service as pomeshchiki on a provincial basis. Despite the parallels with the Mughals, the socio-economic context of the two systems could not have been

\footnotetext{
106 Isabel de Madariaga, Ivan the Terrible: First Tsar of Russia (New Haven, 2005) 15. Cf. Nancy Shields Kollmann, Kinship and Politics: The Making of the Muscovite Political System, 13451547 (Stanford, 1987) 56.

107 Madariaga, Ivan the Terrible, 86.
} 
more different. Whereas in Mughal India ranking was meritocratic in principle and based on a sophisticated monetary economy, mestnichestvo was principally about family precedence. In other words, pomest'ia was nothing more or less than a convenient solution for the court's lack of monetary resources. As family was the main ingredient of mestnichestvo, it could not be as easily manipulated by the ruler as mansab, which also explains why it was abolished in 1682 to give the ruler more leeway to appoint in accordance with ability and experience. ${ }^{108}$

In sum, from its very beginning, the Grand Duchy of Muscovy had a splintered and factionalized nobility that depended on service to the state, which was funded by pomest'ia. There was no room whatsoever for extensive military households - only very few served in the retinue (druhzina) of the ruler at the dvor; most of the other military elites were local landholders who were summoned only at times of danger. Hence, the boyars were a landed group of elites whose position lay somewhere between the rooted European nobility and the more mobile Mughals mansabdars. Overall, there seems to be little doubt that, in comparison to their European and Asian counterparts, the aristocracy of Muscovy was seriously abased. ${ }^{109}$

\subsection{The Crimean Warband}

Although its difficult ecological conditions made Muscovy's court and aristocracy relatively poor, they also saved it from permanent nomadic conquest. ${ }^{110}$ As we have seen already, Muscovy simply lacked the resources and the open landscape of northern China or northern India which facilitated the esprit de corps and logistics of (semi-) nomadic cavalry armies. As far as the landscape

108 Gustave Alef, The Origins of Muscovite Autocracy. The Age of Ivan III (Berlin, 1986) 222; Gustave Alef, 'The Crisis of the Muscovite Aristocracy: A Factor in the Growth of Monarchical Power', Forschungen zur Osteuropäischen Geschichte 15 (1970) 15-59; Gustave Alef, 'Reflections of the Boyar Duma in the Reign of Ivan III', The Slavonic and East European Review 45 (1967) 76-123; Hartmut Rüss, Herren und Diener: Die soziale und politische Mentalität des Russischen Adels. 9.-17. Jahrhundert (Cologne, 1994). See also the works of Ann M. Kleimola: 'The Changing Face of the Muscovite Aristocracy. The 16th Century: Sources of Weakness', Jahrbücher für Geschichte Osteuropas 25 (1977) 481-493; 'Up through Servitude: The Changing Condition of the Muscovite Elite in the Sixteenth and Seventeenth Centuries', Russian History/Histoire Russe 6 (1979) 210-229; 'Military Service and Elite Status in Muscovy in the Second Quarter of the Sixteenth Century', Russian History/Histoire Russe 7 (1980) 47-64.

109 Richard Hellie, 'Thoughts on the Absence of Elite Resistance in Muscovy', Kritika: Explorations in Russian and Eurasian History 1 (2000) 5-20.

110 Which does not mean Moscow was not incidentally razed by nomadic armies: in 1237 by the Mongols, in 1382 by the Golden Horde, in 1571 by the Tatars of the Crimea. 
is concerned, though, this was not the case for the extensive Pontic Steppes beyond Russia's southern frontier, in the area now known as Ukraine, from ukraina, literally meaning 'borderland' or 'march' in Russian. Hence, this region was part of the early Mongol conquests that destroyed Kiev, the city which for centuries had been the main cultural and political centre of Russia. Devastated by the nomadic invasion, it actually became the new heartland of one the four Chinggisid successor empires, the so-called ulus of the Golden Horde, or Qipchaq Khanate. Although profiting from its commercial links with the Black and Mediterranean Seas, the area appears to have experienced a catastrophic decline as a result of both epidemics and the destruction of its economic bases at Azov, Astrakhan, and Urgench under Timur's campaigns in the 139os. ${ }^{111}$

From the second quarter of the fifteenth century the Golden Horde fragmented into various successor states, which created a new balance of power among five political entities, each of medium economic and political might: (1) Muscovy itself; (2) the Crimean Khanate, nominally under the Ottomans after 1745; (3) the Great Horde, replaced by the Astrakhan Khanate in 1502; (4) the Kazan Khanate; and, finally, (5) the Tiumen' Khanate or Sibir. In fact, the four Tatar Khanates should not be considered fully nomadic states but instead, like so many polities in the Middle Zone that have been discussed so far, as a mixture of nomadic and agricultural communities under the leadership of so-called 'begs'. The term Tatar itself did not necessarily refer to nomads but denoted almost all non-Christian inhabitants, mostly with a Turkish background and of Muslim faith. In any case, at the interstices of these enclaves of political centralization and mixed economies, there were truly pastoral groups such as the Nogais, Bashkirs, Kalmyks, and Kazakhs. Moscovy's military successes against Kazan and Astrakhan were in no small degree based on its alliance with these groups, and in particular the Nogais, who delivered crucial transport services and, above all, a large number of excellent warhorses. Coming from Kazakhstan, the Tibetan Buddhist Kalmyks arrived in the Volga plain only in the 1620 . Their migration instigated the building of the $800-\mathrm{km}-\mathrm{long}$ Belgorod Line, the first of a long series of south Russian lines of fortification that started to constrict the available grazing space of these pastoralists and actually forced the Kalmyks to move back eastward again in the 1770s, where they were incorporated into not the Russian but the Qing military system. ${ }^{112}$

\footnotetext{
111 Edward Louis Keenan Jr., 'Muscovy and Kazan: Some Introductory Remarks on the Patterns of Steppe Diplomacy', Slavic Review 26, no. 4 (1967) 553.

112 Michael Khodarkovsky, Russia's Steppe Frontier: The Making of a Colonial Empire 1500-1800 (Bloomington and Indianapolis, 2002) 132-133.
} 
Focussing on the political organization of the Tatar khanates it is remarkable that they, like the other parts of the Middle Zone discussed above, more or less retained the structure of the Turko-Mongolian warband. Even in the details, the system of the Crimean Khanate under Mehmed Giray (r. 1514-1523) and Sahib Giray (r. 1532-1551) comes very close to that of the early Timurids, including Babur. In elite society, there was a hierarchy at the top of which was the khan himself, who was followed by his immediate family members: his eldest sons, other sons, and members of the royal family called oghlans. Many of them were sultans with positions of command. As well as kith and kin, there were the so-called begs, who were referred to as qaraču or heads of the four principal 'tribes', their sons or mirzas, and other so-called nökörs, who were also known as emeldesh or ički (insider) begs, all of whom served the khan as intimate comrades in the court and elsewhere. Also very much along the lines of TurkoMongol tradition, the four 'tribes' were not strict ethnological categories but rather consisted of mixed groups in the manner of those discussed earlier in the case of the Manchu mukun and Timurid tümen. In principle, as much as nökör overrode tribe, the position of client overrode kinship, with the latter becoming merely fictitious and/or used metaphorically.

Interestingly, in 1533 Sahib Giray attempted to end his dependence on his traditional 'tribal' following by introducing the Ottoman model of the Janissaries through the enlistment of a number of musketeers from outside these circles, from 'among the rabble of the people'.113 As shall be seen, the Muscovite rulers would do exactly the same, at first in the form of the pishchal'niki or harquebuzzers, and later, from 1550, by using the so-called strel'tsy who replaced them, and who were also musketeers in the model of Janissaries, operating on foot but, unlike the latter, consisting of free men instead of slaves. ${ }^{114}$ These personal guards, recruited from the lower levels of society, provided an attractive new counterbalance either against the nökörs in the case of the Crimean Khan or against the boyars in the case of the Tsar. It should be stressed here that although their personal nature made these guards look like the warband's nökörs, in principle they are different as they neither provided an imperial elite

113 Inalcik, 'The Khan and the Tribal Aristocracy', 445-466; see also Beatrice Forbes Manz, 'The Clans of the Crimean Khanate, 1466-1532', Harvard Ukrainian Studies 2 (1978) 282309; U. Schamiloglu, 'The Qaraçi Beys of the Later Golden Horde: Notes on the Organization of the Mongol World Empire', Archivum Eurasiae Medii Aevi 4 (1984) 283-297; Craig Kennedy, 'Fathers, Sons, and Brothers: Ties of Metaphorical Kinship between the Muscovite Grand Princes and the Tatar Elite', Harvard Ukrainian Studies 19 (1995) 292-301.

114 For a discussion of the Ottoman background of these new musketeer units, through the agency of Ivan Semonovich Peresvetov, see Madariaga, Ivan de Terrible, 87-91. 
nor represented the empire's elite as a whole. As with other imperial guards in sedentary empires, they were a much more isolated and purely military force than the various forms of the nomadic warband that we came across in our northern Middle Zone.

\subsection{The White Tsar}

One of the Golden Horde's successor states was Muscovy itself. The Nogais called its ruler the White Tsar; the colour symbolizing good fortune and the western location within the Mongol realm. ${ }^{115}$ There are many reasons to link Muscovy's rise to empire with the emergence of the Golden Horde. For example, economically speaking, it was only within the framework of the economic demands and opportunities created by the later Golden Horde that northeastern Russia could recover from the earlier devastation created by the Mongols. ${ }^{116}$ Likewise, in political terms, the Khan of the Golden Horde confirmed the Grand Princes of Muscovy as legitimate but subordinate rulers. In addition, Ivan I (r. 1325-1340) received a Mongol commission to gather the tribute for the Khan from other Russian princes. ${ }^{117}$ We also know that from the fourteenth century onwards, the Grand Princes relied on Tatar manpower to expand their territory further west, towards Tver and Novgorod. Hence, their armies consisted primarily of mounted archers with composite bows. The leaders of these Tatar forces were often members of the Chinggisid dynasty, and as Chinggisid tsarevichi they not only gave power but also authority to the Great Prince of Muscovy. Two sons of Ulugh Muhammad, the Khan of the Golden Horde, became vassals of Grand Prince Vasily II (r. 1415-1462) and founded, under Russian protection, the Khanate of Kasimov, and its Chinggisid ruler helped Vasily II to regain his throne in the Russian civil wars of the mid-fifteenth century. Ivan IV, also known as grozni, literally the 'awesome' but better known as the Terrible (r.1547-1584), grew up among Chinggisid princes and even abdicated for a year in favour of one of them, who became known as the Grand Prince of Russia Symeon Bekbulatovich. 118

115 Michael Khodarkovsky, 'The Non-Christian Peoples on the Muscovite Frontiers', in: Maureen Perrie, ed., The Cambridge History of Russia, Volume 1: From Early Rus to 1689 (Cambridge, 2006) 323 .

116 Janet Martin, 'North-eastern Russia and the Golden Horde (1246-1359)', and 'The Emergence of Moscow (1359-1462)', in: The Cambridge History of Russia, Volume 1, 127-187.

117 Nicholas V. Riasanovsky, A History of Russia (Oxford, 1993) 97-101.

118 Madariaga, Ivan the Terrible, 298-311; 437. One possible explanation for this act lies in the Indian story of Barlaam and Josaphat. Following that story, the physician and magus Bomelius had produced a horoscope for Ivan, showing that in the years $1575^{-1576}$ a Grand 
Indeed, it seems that Ivan IV had a crucial decision to make: should he opt for the Polish-Lithuanian or the Tatar model, perhaps now in its latest, Ottoman version? At the beginning of his reign, he had made important strides against the Tatars by the incorporation of Kazan (1552) and Astrakhan (1556); Sibir would soon follow in 1582. Even earlier, Muscovy had started to emancipate itself from the Tatar embrace after beating them at the Field of Kulikovo in 1380 under Dmitri Donskoi. A century later, after another confrontation on the River Ugra under Ivan III, Muscovy ceased to regard the Tatars as its overlord. But this did not mean their institutions immediately lost their attraction, particularly since the alternative models of the West were not yet considered good enough. Ivan IV once complained that he often felt like the Polish king: excluded from power and ordered about by his servants, a ruler in name but not in fact. In other words, the first option involved close cooperation with his increasingly powerful service boyars, which could itself only lead to the loss of his own position.

Whatever he decided, in late 1564 he suddenly abandoned Moscow for the small town of Aleksandrov. He abdicated, denouncing both the boyars and the clergy. Both begged him to return, which he did, but only on his own terms: the creation of a special subdivision in the state, known as oprichnina, consisting of about one third of the realm, to be managed entirely at his own discretion. At the same time he expected an endorsement of his right to punish evil-doers and traitors as he saw fit. For our present purpose it is crucial to note that the term oprichnina also came to designate a new corps of about 1000-6ooo personal servants called oprichniki-all dressed in black and riding black horses. It is hard to understand Ivan's motivations for what seems to be a desperate move away from the court and its 200 or so boyar families. ${ }^{119}$ In a way it is reminiscent of Emperor Ming Zhengde's move to the so-called Leopard Quarter about half a century earlier; like Ivan, the Zhengde emperor decided to establish a brand new palace outside the established court so that he could conduct business on his own terms without the interference of civil officials. Here he followed his plan to revive the Ming military without the obstruction and criticism of officialdom. He surrounded himself with a court

Prince of Russia was to die. All this was confirmed by a comet and a planet conjunction. A similar temporary abdication happened in 1594 when the Safavid emperor Shah 'Abbas I abdicated for three days after his chief astrologer Jalal al-Din Munajjim Yazdi foretold the death of an Iranian ruler. Stephen P. Blake, Time in Early Modern Islam: Calendar, Ceremony and Chronology in the Safavid, Mughal, and Ottoman Empires (Cambridge, 2003) 153.

119 Riasanovsky, History of Russia, 150-155. See also Gunnar Opeide, 'Making Sense of Opričnina', Poljarnyj Vestnik: Norwegian Journal of Slavic Studies 3 (2000) 64-99. 
of his own choosing, comprised in large measure of foreigners and military men who, under his direction, began to retrain the imperial armies. ${ }^{120}$ Although very similar in motivation, in China the emperor's sudden exodus did not have serious consequences for the administration as a whole. While the emperor's behaviour may have been interpreted as unconventional or even outlandish, business generally went on as usual. This was not the case in Russia, where the oprichnina unleashed a veritable reign of terror, which actually increased the Tsar's hold on the princes and the service elites who had gradually turned into an obstreperous hereditary aristocracy.

So should the oprichnina be regarded as the Tatar option? Isabel de Madariaga makes a strong argument they may have been inspired by Ivan's Tatar wife Maria Temriukovna, a niece of the later, 'mock' Prince Symeon Bekbulatovic. Indeed, her brother, Prince Michael Cherkassky-another member of what seems to be an incredibly influential Qipchaq 'tribe'-became an important leader of the oprichniki. ${ }^{121}$ Whatever its inspiration, the oprichnina represents a fascinating attempt to start an empire from scratch with a brand new personal warband. In Russia, though, it could never expand in the way it had done under Chinggis Khan, Babur, or Nurhaci.

After Ivan's death, the struggle between the old and new elites continued and opened the door to the regency of Boris Godunov, who even became Tsar in 1598. After defeating both the high-born princelings and the low-born oprichnina guard, he consolidated the boyar elite, not in their landed holding but by offering positions in the expanded chancellery secretariat. His policies opened the way for the emergence of the Romanov family, but only after they had survived the last attempt to impose a Tatar-like warband on Russia during the Time of Troubles.

\subsection{A Retro Warband: The Cossacks}

In many ways the Time of Troubles $\left(16 \circ 3^{-1613)}\right.$ was part of the more global seventeenth-century crisis. Muscovy experienced the almost natural aftereffects of a relatively stable sixteenth century, which had seen economic stability, a doubling of the population, and staggering territorial expansion. This was followed, though, by increasing demographic pressures that caused an economic crisis that had its beginnings in the long Livonian War $\left(155^{8-1582}\right)$ in the West and a series of natural disasters at the turn of the century. Very much like the economy, political troubles in the early seventeenth century naturally fol-

120 James Geiss, 'The Leopard Quarter during the Cheng-te Reign', Ming Studies 24 (1987) 1-38.

121 Madariaga, van the Terrible, $186-188$. 
lowed an earlier period of political expansion, in particular into the southern steppes, which brought millions of new inhabitants into the empire, many of whom were not yet settled as peasants and were still moving around in search of a living.

The incorporation of the southern steppes had been made possible by two policies. One was the building of fortified lines (zaseki) that warded off nomadic raids and also sealed off their nomadic trails. The other was the support of highly mobile Cossack warbands that could fight the Tatars on their own terms. It is difficult to make a clear difference between these Cossacks and Tatars. Both were often organized in open, conscriptive groups of wandering traders-cum-warriors. The origin and background of the Cossacks was, however, different, as they incorporated mainly Slavic immigrants from the north, many of whom had a peasant or serf background, and most of whom were Christians. As such, these were frontier guardsmen who combined raiding with trade, but increasingly also agriculture. Tatars, on the other hand, often had a pastoralist Turkic background and were primarily Muslims. Michael Khodarkovsky sees the Cossacks as the 'mirror image' of their nomadic adversaries who, like them, chose to live off booty and pillage. ${ }^{122}$ On the southern frontier, both groups merged into the hybrid Cossack category, standing somewhere midway between such real pastoralists as the Nogai and the more 'urban' enclaves of the Tatar Khanates. ${ }^{123}$ In terms of spirit and structure, the Cossacks had all the elements of the nomadic warband that have been noted for the Jurchens and Turks before their Chinese and Indian conquests. In Russia, however, it always remained a pre-conquest, frontier phenomenon but, as such, consciously stimulated, manipulated, and controlled by the court. Hence, as in the case of the Banners, we have a sedentary empire recreating and exploiting a subsidiary warband to implement imperial control. The Russian case is different, though, because the Cossack warbands were not used as an internal pool of loyal administrators but were projected outward to the frontier to fight other warbands and to expand agriculture. Russian rulers knew very well that in the end it was the plough, not the sword, that would win the steppe, as much as 'the chicken would prevail over the horse. ${ }^{124}$ Obviously, this would also be the natural end of the nomadic warband and, with that, the Cossack way of life. ${ }^{125}$ We should not forget, though, that during the Time of Troubles this outcome

\footnotetext{
122 Khodarkovsky, Russia's Steppe Frontier, 224.

123 Günter Stökl, Die Entstehung des Kosakentums (Munich, 1953).

124 Keenan Jr., 'Muscovy and Kazan', 557.

125 Brian J. Boeck, Imperial Boundaries: Cossack Communities and Empire-Building in the Age of Peter the Great (Cambridge, 2009).
} 
was far from foreseeable and it could all have been quite different if only the Cossacks had won the day. ${ }^{126}$

The opening of the southern frontier had caused an increasing influx of Tatar warriors into the empire. Some high-ranking Tatars became close satellites of the court, receiving various pomestia or even towns for their kormlenie (feeding). ${ }^{127}$ More important than these Tatars, though, was the increasing Cossack element in the Russian army, mainly from the southern frontier. When economic conditions went from bad to worse at the end of the sixteenth century, these Tatar and Cossack warbands could no longer be paid. During this time their numbers even increased as peasants and serfs moved away from the forest heartlands to find refuge in the south, where they were incorporated by some very charismatic Cossack warband leaders or atamans; as Chester Dunning so aptly puts it, more and more Russians 'went cossack'.128

One of the Cossack leaders was a certain Ivan Isaevich Bolotnikov. He was captured by the Turks and served as a galley slave before escaping and returning to Russia through Poland. Another colourful figure was one Ivan Martynovich Zarutskii who, having been taken prisoner by the Crimean Tatars, escaped to the Don Cossacks, where he gained a reputation for exceptional bravery, and subsequently joined Bolotnikov's forces. Either of them could have been a Babur or a Nurhachi, carving out empires of their own, had they not lived in Russia. Instead of claiming the throne for themselves, they pushed the claims of an endless series of Tsarevich pretenders. And although they seriously threatened Moscow, they never managed to take it, and in the end were undone

126 Maureen Perrie, 'The Time of Troubles (1603-1613)', in: The Cambridge History of Russia, Volume 1, 409-431; Maureen Perrie, Pretenders and Popular Monarchism in Early Modern Russia: The False Tsars of the Time of Troubles (Cambridge, 1995); Ruslan G. Skrynnikov, Times of Troubles: Russia in Crisis (Gulf Breeze FL, 1988); Chester S.L. Dunning, Russia's First Civil War: The Time of Troubles and the Founding of the Romanov Dynasty (Pennsylvania, 2001).

127 Donald Ostrowski, 'The Growth of Muscovy (1462-1533)', in: The Cambridge History of Russia, Volume 1, 213-239; Donald Ostrowski, 'Troop Mobilization by the Muscovite Grand Princes (1313-1533)', in: Eric Lohr and Marshall Poe, eds., The Military and Society in Russia, 1450-1917 (Leiden, 2002) 19-40; Janet Martin, 'Tatars in the Muscovite Army during the Livonian War', in: Eric Lohr and Marshall Poe, eds., The Military and Society in Russia, 14501917 (Leiden, 2002) 365-387; Bulat R. Rakhimzyanov, 'The Muslim Tatars of Muscovy and Lithuania: Some Introductory Remarks', in: Brian J. Boeck, Russell E. Martin and Daniel Rowland, eds., Dubitando: Studies in History and Culture in Honor of Donald Ostrowski (Bloomington, 2012) 117-128.

128 Chester S.L. Dunning, 'Cossacks and the Southern Frontier in the Time of Troubles', Russian History 19 (1992) 59. 
by the 'national militias' who, in 1613, picked Michael Romanov as their new Tsar. After the repression of the Cossacks, the latter increasingly served as mercenaries under boyar command or were pushed further along the basins of the rivers Don, Volga, Terek, and Iaik towards the southern frontier. Here they began to set up their own organization which made them more answerable to the central authorities in Moscow until, in the eighteenth century, their leaders started to owe their authority not to their constituency but to the Tsar. ${ }^{129}$ At the same time, however, they continued to stir social unrest and revolts. One of these revolts, under Bogdan Khel'nitskiy (1648-1657), was directed against Poland-Lithuania and enabled Muscovy to incorporate many of the Ukrainian Cossacks into its own army and large parts of the Ukraine into its territory. Much more of a threat to Muscovy itself were the revolts of Sten'ka Razin (16701671) and Emelian Pugachev (1773-1775), but now all the unrest was happening far from the capital and it was clear to all that the sedentary way of life had definitively come to stay in Russia, not only in the forest belt but also in the steppes. ${ }^{130}$

Why did Bolotnikov and Zarutskii fail where Babur and Nurhachi had succeeded? Why could their warbands not serve as the basis of conquering and sustaining an empire? The answer brings us back to Russia's ecological and economic conditions. Both Tatars and Cossacks simply lacked the resources to sustain the necessary initial expansion of the warband that was noted in the case of Babur and Nurhaci, who could take as much as they liked from the almost endless resources of the Chinese and Indian economies. Furthermore, their paths had been paved by their Jurchen and Afghan predecessors. The Cossack warband was never able to become large enough to beat the better organized and paid Russian army under boyar command; however, in the early seventeenth century the Russian victory was far from decisive and the outcome could still have been different.

What really contained the Cossacks in the following decades and centuries was, however, the gradual move towards a new, European-style infantry army supported by a growing administrative apparatus of various chancelleries or prikazy, the most important of which was the Military Service Chancellery (Razriad) established under Alexis (r. 1645-1676). Indeed, the increasing number of prikazy gave new opportunities to boyars whose main task remained primarily the provisioning and funding of the army. All this had become neces-

129 Boeck, Imperial Boundaries, 19 o.

130 Philip Longworth, The Cossacks (London, 1969). For a Ukrainian perspective, see Linda Gordon, Cossack Rebellions: Social Turmoil in the Sixteenth-Century Ukraine (Albany, 1983). 
sary not because of threats from the Tatars and Cossacks, but in order to fight similar armies that served the Poles and Swedes on the western front. It was Peter the Great (r. 1682-1721) who tried to use this opportunity to make himself more autonomous from his boyars - a desire that had already been seen under Ivan IV when he started the oprichnina.

Many of the reforms were implemented by German and other foreign officers. At the same time, it is important to stress that the Russian army never became a mercenary army as was the case in other European countries. It actually became increasingly Russian, increasingly based on conscription. Even non-Russian recruits, like the Ukrainian Cossacks, became increasingly Russified. Although pomest'ia was turned into votchina, both became subjected to a military service requirement as regulated by new censuses. The huge increase in the size of both the army and prikazy was paid for by the levying of a poll tax on the increasingly fixed and defined population. The latter grew out of the famous 1649 Ulozhenie, which had codified serfdom as a compromise with the provincial middle service class cavalry who had become more and more concerned about the viability of their estates. Meanwhile, in the tradition of the strel'tsy but starting from scratch, Peter had created his own personal guard. In his adolescence Peter had gathered around him the sons of boyars and organized them into two regiments of boys who fought mock battles under his command. These so-called toy regiments (poteshnye polki) were named Peobrazhenskii polk and Semenovskii polk after the suburbs where they originated, and became the nucleus of his new army. ${ }^{131}$ This practice was later repeated by Peter III's Holsteiners and Paul's Gatchina regiment. At the same time, following the example of the palace schools of the Ottomans as well as the so-called Ritterakademien in other European polities, Peter established elite military academies that were meant to train his officers in the latest gunpowder technology and to lead them to be even more closely attached to the Tsar. Access to these guards and academies increasingly defined one's status. ${ }^{132}$

\footnotetext{
131 Alfred J. Rieber, The Struggle for the Eurasian Borderlands: From the Rise of Early Modern Empires to the End of the First World War (Cambridge, 2014) 201-202. I am grateful to Hans Voeten for explaining the specific meaning of these terms to me.

132 For the developments of the seventeenth- and eighteenth-century nobility and army, see R.F. Hellie, Enserfment and Military Change in Muscovy (Chicago, 1971); Robert O. Crummey, Aristocrats and Servitors: The Boyar Elite in Russia 1613-1689 (Princeton, 1983); John L.H. Keep, Soldiers of the Tsar: Army and Society in Russia 1462-1874 (Oxford, 1985); Marshall Poe, 'The Military Revolution, Administrative Development, and Cultural Change in Early Modern Russia', Journal of Early Modern History 2, no. 3 (1998) 247-273; Dominic Lieven, 'The Elites', in: Dominic Lieven, ed., The Cambridge History of Russia, Volume 2:
} 
Indeed, after Peter, and in particular after Catherine II (r. 1762-96), officers of the Guard Regiments increasingly started to build loyalties with their fellow officers and created a new class of military intelligentsia. Even ordinary soldiers became more tied to their regiments, as their children were forced to enter garrison schools that were meant to instil some basic education, and, above all, discipline and exercise. This horizontal kind of corporatism leads one historian even to use the term Praetorianism, which, in the nineteenth century, even started to threaten the Tsar himself, as was the case during the 1825 Decembrist Revolt. 133

The new corporatism, based on the Imperial Guards and Academies, once again raises questions over the warband and 'asabiyya. Indeed, Peter's creation of his own personal guard, selected from the main boyar families and which instilled a new regimental identity, brings to mind Chinggis Khan's keshik. At the very moment that officer corporatism gains substance and spreads across the empire and different levels of society, we may superficially recognize something that comes quite close, if not to the Chinggisid prototype itself, to its postnomadic derivatives under the Manchus and Timurids. Although the Cossacks clearly elaborated on the Turko-Mongolian model, Peter's new standing army seems to be something different and much closer to early modern European examples, which may have had similar functional objectives as the Chinggisid warband, but apparently had a completely different, sedentary rather than a nomadic origin. In the case of Peter's guards there seems to be nothing that compares to the flexible, all-inclusive nature of the Turko-Mongolian keshik, which encompassed both military and administrative functions and represented the elites of all the subsidiary warbands that exploited the sedentary populations through collective appanages. Indeed, the Petrine army seems to have grown naturally from the smaller and much more isolated and restricted imperial guard of the strel'tsy. It was only later, during the eighteenth century, when the economic basis of the empire increased and was managed ever more effectively by an enlarged bureaucracy that the disciplining powers of this new standing army grew at an unprecedented level and really started to make a difference against the nomadic warbands to its south and east.

Russia 1689-1917 (Cambridge, 2006) 225-244; William C. Fuller Jr, 'Chapter 25: The Imperial Army', in: Dominic Lieven, ed., The Cambridge History of Russia, Volume 2, 530-553. 


\section{The Ottoman Middle East: From Ghazis to Janissaries}

\subsection{Osman's Men: Beylik and Sanjaq}

South of Russia our northern Middle Zone continues into Anatolia and to the west faces the heartland of the Byzantine Empire. At the beginning of our period, the Asian part of that empire was undergoing a process of increasing nomadization. Although starting in the eleventh century, its peak occurred two centuries later when, due to the Mongol campaigns into the Pontic Steppe and Iran, more and more Turkic pastoralists moved onto the semi-dry Anatolian plateau, penetrating deep into its still sedentary western valleys under the control of the Byzantines. Meanwhile, the Seljuq Empire, a product of the first nomadic movement, was more or less crushed by the Mongol 'hammer' battering against the Byzantine 'anvil'. After a short interlude under the Golden Horde, Anatolia was under the control of the Ilkhans from their remote summer and winter quarters, in Azerbaijan and the Mughan Plain respectively. Even more so than under the Seljuqs, the Ilkhanid period bound eastern Anatolia closely to the political fortunes of north-west Iran. ${ }^{134}$

Along the shifting frontier between the expanding Ilkhans and the retreating Byzantines emerged various Turkic marcher lords who made a living from raiding the countryside and lending their military services to the highest bidder, whether Christian or Muslim. Some of them carved out their own little polities or beyliks, a few even becoming truly cultural hubs for refugee Persian intellectuals searching for new jobs after the Mongol invasion. One of these beyliks was created by Osman and his band of nökörs - hence called the Ottomans-in the north-west of Anatolia. One of the hidden secrets behind the Ottoman success story was that, even before the fall of Constantinople in 1453, they were able to build a bridgehead across the Dardanelles which made it possible to channel the surplus of Turkish manpower from Anatolia to the Balkans and, in addition, to recruit new manpower from the latter. As a consequence, it was due to their hold on the Balkans that the Ottomans were able retain their home base in Anatolia and even to withstand the devastating campaigns of Timur at the start of the fifteenth century. ${ }^{135}$ As was plain to see, even for later generations who romanticized the events, the prime political instrument with which the Ottomans had achieved all this had been the Turko-Mongolian warband.

\footnotetext{
134 Charles Melville, 'Anatolia under the Mongols', in: Kate Fleet, ed., The Cambridge History of Turkey, Vol. 1: Byzantium to Turkey 1071-1453 (Cambridge, 2009) 101.

135 Halil Inalcik, An Economic and Social History of the Ottoman Empire. Volume 1: 1300-1600 (Cambridge, 1994) 11-13.
} 
Whatever one may think of the notorious ghazi thesis as presented by the overly romantic Austrian historian Paul Wittek, there is no doubt whatsoever that the Ottomans were one of many warbands that were active in the Anatolian frontier zone. ${ }^{136}$ What is also clear, though, is that all our sources date from a period much later than the life and times of the founder of the warband, Osman Ghazi (c. 1290-1324). Hence, it is not at all surprising that Ottoman historians, defending their patrons against the much better genealogical claims of the Timurids, have interpreted the early events in an excessively Islamic light, as a heroic fight against the infidel. Removing the anachronistic idea of a civilizational clash between Islam and Christendom, there is still much to appreciate in the concept of the ghazi warlord who in seasonal razzias - from ghaziya or raiding - creates his own band of mounted warriors and comrades (in Turkish yoldash but in the sources also called nökör) and brings them under his banner or flag (sanjaq). According to the doyen of Ottoman studies, Halil Inalcik, this process of creating the Ottoman warband entailed a dissolution of kinship ties with the exception of those of the leader's family. The Holy War ideology, as much as the success of the actual raids, reinforced ties within the band to produce a cohesive social group that centred around the leader. ${ }^{137}$ With these two sentences we are back at the models of the Chinggisids and Ibn Khaldun with which we started this essay. Interestingly, Inalcik adds that it was not the shari'a-minded 'ulama' but the mystical Sufi dervishes who embodied the ghaziya spirit and brought to the leader's authority the spiritual sanction of Islam. Here we come very close to the story of the Sufi Safavid warlords who emerged only slightly later in the same Turkic climate so typical of eastern Anatolia, Azerbaijan, and northern Iran. Nevertheless, we should be on our guard by now as we simply do not know how much of the religious fervour at the very beginning of the Ottoman and Safavid movements was projected onto the events ex-post-facto by both Ottoman and Ottomanist historians, eager to give them some higher purpose. ${ }^{138}$

Whatever their ideological drive, looking at the various Turkish marcher lords in Anatolia in this period, we can recognize something of the Chinggisid warband. Apart from the idea of nökörs, it seems that at the beginning of the fourteenth century entire provinces were given to military commanders (beys)

136 For a recent discussion of Wittek's ideas, see Paul Wittek, The Rise of the Ottoman Empire: Studies in the History of Turkey, Thirteenth-Fifteenth Centuries (London, 2012) as edited and introduced by Colin Heywood. See also Kafadar, Between Two Worlds.

137 Halil Inalcik, 'The Question of the Emergence of the Ottoman State', International Journal of Turkish Studies 2 (1981-1982) 71-79.

138 See, however, the comments by Peter Rietbergen regarding Ismail's poems in this volume. 
as their banner or sanjaq, which comes close to the Timurid appanage. At this early stage, sanjaq, very much like the Timurid tümen, designated a military unit without the territorial connotation that it would receive later. Sanjaq Beys had both civil and military functions. Similarly, the word timar, which later became known as the individual prebend of a cavalry trooper, still indicated large grants of land to subsidiary warband leaders at full liberty to arrange matters as they saw fit. Both sanjaq and timar were meant to incorporate the regional elites into a subsidiary warband or curb them by creating new provincial commanders coming from the ruler's own warband. ${ }^{139}$ Only later in the fifteenth century did the sanjaq bey become a provincial official in command of a specific group of timar-holders and their lands, still not neatly covering the borders of a province but, at least in theory, under the surveillance of the court.

Despite such similarities, Anatolia was not Mongolia. As cogently expressed by Rudi Paul Lindner, the beyliks built their power on the nomads but without having enough of them. ${ }^{140}$ It was only by developing and exploiting the sedentary resources in Rumelia that one of them managed to become an empire. So the Ottomans were nomadic chiefs who made their fortune in areas of relative agrarian wealth. Like China in the case of the Mongols and Jurchens, the Rumelian and Anatolian resources were initially substantial enough for the Ottomans to support the persistence of the nomadic warband. As they were soon to find out, though, operating in Europe was an entirely different ballgame. European circumstances did not allow for nomadic movement on a grand scale as was still possible in the eastern Anatolian extensions of the Arid Zone. What became increasingly important in this area were the drilled operations of foot soldiers as explored by the first mercenary powers hired by the South and Central European powers. As they were increasingly equipped with the latest gunpowder weaponry, from the fifteenth century onward, infantry troops started to make real headway against cavalry, especially in the European logistical context where the size of the latter always remained limited. Although it would at least take another two centuries and another round of new

139 Pál Fodor, 'Ottoman Warfare, 1300-1453', in: The Cambridge History of Turkey, Volume 1, 198; Linda Darling, 'The Development of Ottoman Governmental Institutions in the Fourteenth Century: A Reconstruction', in: Vera Costantini and Markus Koller, eds., Living in the Ottoman Ecumenical Community: Essays in Honour of Suraiya Faroqhi (Leiden, 2008) 24. For later developments, see Colin Imber, The Ottoman Empire (Basingstoke, 2009) 164203.

140 Rudi Paul Lindner, 'Anatolia, 1300-1451', in: The Cambridge History of Turkey, Volume 1, 107, 121. 
gunpowder innovations before infantry really won the day, for the Ottomans, having to operate in the European arena, it became necessary to recruit soldiers among the peasantry in the Balkans. All this gave rise to the introduction of devshirme or 'collection' whereby the sultans levied slaves from among their own Christian subjects, employing them, not as horsemen as in the case of the Turkic Mamluks in Egypt, but as highly disciplined new infantry units called Janissaries.

So although there are many reminders of some earlier developments in our Middle Zone, the Ottoman version of the Turko-Mongolian warband had a relatively short lifespan. Until the fifteenth century it worked well to mobilize and incorporate nomadic manpower and channel it towards the western frontiers in Anatolia and the Balkans. Soon the Ottomans found out, though, that in its original guise the warband could not operate in the sedentary surroundings of western Anatolia and south-eastern Europe. Neither was it big enough to really make an impression on their eastern Timurid, Mamluk, or Safavid neighbours. Under these circumstances, investing in a combination of infantry and gunpowder technology made perfect sense.

The idea of the warband held out longest along the shifting frontier $(u j)$ of the Balkans. In the guise of the so-called akinjis, or frontier raiders, we recognize something of the Cossack phenomenon that we have analysed already for the Russian frontier and which represented a conscious policy of the court to stimulate both settlement and territorial raiding against the enemy. In the early stages, this frontier zone attracted not only the Ottomans and other Turkic ghazis but also European crusaders. Organized in the mercenary Company of the Catalans, the latter carved out their own fourteenth-century polity in Athens. ${ }^{141}$ Although lacking a nomadic background and thus not accompanied by their families, the Christian Catalan Company was not all that different from the Turkish beyliks. Although very effective in their own ecological niche, both lacked the nomadic and sedentary resources to use the warband for conquering the extensive empire as achieved by the great world conquerors Chinggis Khan and Timur, or indeed by their Mughal and Manchu colleagues Babur and Nurhaci. The Ottomans had to develop an alternative strategy.

\subsection{Beyond the Warband:Devshirme}

The Ottomans who conquered large parts of northern Africa and south-eastern Europe in the sixteenth century were not leading a nomadic warband anymore

141 Angeliki E. Laiou, Constantinople and the Latins: The Foreign Policy of Andronicus II: 12821328 (Cambridge Mass., 1972) 127-200. 
but a salaried slave army assisted by timar-based cavalry troops or sipahis. As mentioned already, using military slaves was nothing new, certainly not in the Islamic world. In the Middle East it dates back to the ninth-century Abbasids but the Seljuqs were the first to possess a substantial army of military slaves. In the mid-thirteenth century, one of their successor states, the Ayyubids of Egypt and Syria, began to recruit large number of Turkish slaves from the Eurasian steppes. After successfully beating off both the Crusaders and the Mongols these slaves created their own Mamluk dynasty and continued to recruit slaves, primarily from the Qipchaq steppes controlled by the Golden Horde. ${ }^{142}$ In the early sixteenth century, it was this slave army, dominated by Turkish cavalry, that was beaten by the Ottoman slave army dominated by 'European' infantry and artillery.

The one element in the sixteenth-century Ottoman army that may still vaguely remind one of a Turko-Mongolian warband was the standing army of six cavalry regiments of the household (kapikulu sipahi), recruited from graduates of the so-called palace schools that were specifically created to train freshly purchased slaves to accompany the sultan on campaign, as well as during ceremonial occasions. The most prestigious among them were the sipahi oğlanlart (cavalry youths) and the silahtar (armbearers), followed by the ulufeci (salaried men) of the right and the left wings, and the garib yigitleri (foreigners) of the right and left wings. From their inception sometime in the fifteenth century their numbers increased from about 2,00o to almost 20,00o by the beginning of the seventeenth century. Yet more important than these mounted troops was the fourteenth-century introduction of an infantry corps. Interestingly, this part of the slave corps did not consist of primarily Turkish recruits but of European Christians who formed a new-style infantry unit of the Janissaries, from yeniçeri, literally meaning 'new army'. Initially these were taken from amongst prisoners of war, most prominently through the various marcher lords, but soon they were primarily collected, whence devshirme, literally 'collection', as slaves from the Christian subjects in the Balkans. Once selected, the Janissary novices received an education and military training, partly at court and partly in the provinces. Before becoming a major building bloc of the imperial army, the Janissaries, like the kapikulu sipahi corps, served as the ruler's bodyguard and sometimes, as individuals, served as the ruler's representative in the provinces. In the sixteenth century, it was primarily this impressive standing army of about 10-20,000 well-trained infantry soldiers, equipped with the lat-

142 Peter B. Golden, An Introduction to the History of the Turkic Peoples (Wiesbaden, 1992) 348349 . 
est gunpowder technology, that delivered the Ottomans their empire, defeating the Safavids at Chaldiran in 1514, the Mamluks at Ridaniyya in 1517, and the Hungarians at Mohács in 1526.

Until the fifteenth century, the Ottoman slave army served as a rather small and isolated imperial bodyguard in a manner similar to those we have seen before under fully sedentary conditions. But when the Janissary ranks swelled and started to serve as the infantry core of the Ottoman army at large, it seems to have been part of a general, European development to create salaried standing armies, as was the case of the so-called bandes d'ordonnance established in France and Burgundy around 145o. Of course, it is also reminiscent of the Russian strel'tsy. Indeed, looking closer at military developments, the Ottoman and Russian developments are strikingly similar. For example, the sipahi cavalry troopers, numbering around 80,000 in the middle of the sixteenth century, were increasingly paid by individual timars granted by the state. As we have seen, this was also the case with their Russian colleagues, who were paid by individual pomest'ia. Both timar and pomest'ia were, like the Byzantine pronoia, given to pay for the individual trooper and as such were different from the larger iqta' or jagir which were bestowed on commanders in Mughal India. In all these cases, it was crucial that prebend-holders were constantly transferred from one place to the other so they could not put down roots and carve out their own little kingdoms. From the sixteenth century onwards, more and more slaves penetrated the ranks of timar-holders. ${ }^{143}$ In fact, if they did not take service at court, the sipahis became an impoverished lot. This process was aggravated by the Ottomans policy to replace timars with revenue farms or çifliks, which gave rise to the emergence of a new urban class of entrepreneurial elites called ayan, often to the detriment of the sipahis.

Yet this situation was not so strange, as the Ottoman-Russian parallel derives mainly from the ecological similarities between the two regions. Both the Ottomans and the Romanovs ruled empires that faced a limited nomadic power that failed to strike at their sedentary cores. It was only at the very fringe of their emerging empires that something of the warband's spirit, in the subsidiary form of Akinjis and Cossacks, could continue, albeit on a small scale and under more settled conditions. In fact, the Romanovs were more successful in this regard as they could profit from an ever retreating nomadic frontier.

143 Fodor, 'Ottoman Warfare', 199-2o9; Imber, The Ottoman Empire, 116-130, 262-294. For an interesting Ottoman-Russian comparison, see Gábor Ágostan, 'Military Transformation in the Ottoman Empire and Russia, 1500-180o', Kritika: Explorations in Russian and Eurasian History 12, no. 2 (2011) 281-319. Like the Russian boyars, the timariots could never develop into that rooted and notoriously obstreperous Polish or Hungarian aristocracy. 
In contrast, due to strong Habsburg, Romanov, and Safavid resistance, the Ottoman frontier was 'closed' in the seventeenth century. As a consequence, the Ottomans could not, like the Romanovs, continue to recruit huge numbers of frontiersmen for the army. In order to keep pace with the ever increasing numbers and firepower of their European adversaries, the Ottomans had no choice but to expand recruitment to the Anatolian peasantry. The result was the creation of Cossack-like warbands of a sedentary nature, not at the fringe but at the heart of the imperial realm. These bands of sekbans, sarica, or levends, the latter quite significantly meaning 'bandit' or 'vagrant', consisted of peasants who had previously been carefully kept out of the military but were now lured by provincial officials to join their retinues or were directly enlisted into the sultan's army. The availability of firearms in the countryside facilitated this move away from land and towards military pursuits. As a result, the state became a significant client for mercenaries organized around units that were ready for hire. ${ }^{144}$

So, whereas the Russian Time of Troubles resulted in the projection of the Cossack warband to the frontier, the Ottoman Time of Troubles struck internally and by creating an armed peasantry — of a kind that had existed in India for many centuries-became an increasing problem. Hence, the so-called mercenary (Celali) rebellion in 1608 proved to be no brief episode but actually became rather endemic, while also undermining the already precarious agrarian balance in Anatolia. A lack of security in the countryside made peasants less willing to stay in the fertile Anatolian plains, which were increasingly left to çiflik-holders who concentrated on animal breeding. Flocks with a few herdsmen promised higher profits than grain or any other crop requiring more labour. It once again showed that Anatolia was part of an Arid Zone where productive sedentary agriculture could not be taken for granted. ${ }^{145}$ By the eighteenth century, recruitment was primarily in the hands of the çifliks-holding ayan who had replaced the dysfunctional old-style timariot sipahis; indeed, at a time when Russia turned towards general conscription, the irregular recruitment of these provincial militias even surpassed the Janissaries and became the standard procedure of Ottoman campaigning. ${ }^{146}$

\footnotetext{
144 Karen Barkey, 'In Different Times: Scheduling and Social Control in the Ottoman Empire, $155^{\circ}$ to 165o', Comparative Studies in Society and History 38, no. 3 (1996) 478; see also her Bandits and Bureaucrats: The Ottoman Route to State Centralization (Ithaca, NY, 1994).

145 Wolf-Dieter Hütteroth, 'Ecology of the Ottoman Lands', in: Suraiya N. Faroqhi, ed., The Cambridge History of Turkey, Volume 3: The Later Ottoman Empire 1603-1839 (Cambridge, 2006) 30 .

146 Virginia H. Aksan, 'War and Peace', in: The Cambridge History of Turkey, Volume 3, 81-
} 
Looking at eighteenth-century developments, one gets the feeling that the historiographical evaluation of the Janissary phenomenon suffers from an exclusively military perspective. Although in a purely military sense the Janissaries lost their efficiency, we should keep in mind that the huge increase of their numbers, from about 20,000 at the mid-sixteenth century to about $400,000(!)$ at the end of the eighteenth century, as well as their increasing geographical spread, must have played a crucial role in enhancing the social cohesion of the empire as a whole. The corps (ocak) as such had evolved from a more or less isolated imperial bodyguard into the core of the imperial army and then into an imperial network that pervaded society as a whole. All this had already begun in the sixteenth century with the granting to Janissaries permission to marry - only bachelors continued to live in relatively isolated barracks. Later, their ranks became more open to outsiders: (adopted) relatives, friends, and clients of Janissaries, many of whom were Turks and Muslims. Although the cohesion of the corps as a whole declined, what remained was a mighty pressure group within the empire that continued to share a culture of imperial service, combined with a specific branch (Bektashi) of Sufi devotion. In addition, after 1740, the demilitarized corps actually increased its financial hold on society and opened up its ranks even further as Janissary salary claims started to be marketed as certificates (esâme). Whatever the complaints about rising corruption and imperial decline, I would argue that the increasing integration of the Janissaries into society actually explains a great deal of the empire's astonishing endurance. ${ }^{147}$ Because they were everywhere, it seems that the integrated 'degenerated' Janissaries, still very much the emperor's men, were even more effective than the segregated 'pure' Manchu banners in keeping the empire together.

\subsection{Coming Full Circle: Mustafa Ali and Ibn Khaldun}

During the sixteenth century, at the height of their imperial conquests, there was a broad, almost Eurasia-wide consensus, stretching from Niccolò Machiavelli in Italy to Iskandar Muda in Aceh, that the Ottoman standing army of Janissaries provided the model par excellence for building and sustaining

117; Idem, 'Whatever Happened to the Janissaries? Mobilization for the 1768-1774 RussoOttoman War', War in History 5 (1998) $23-36$. The Ottomans introduced conscription only in the nineteenth century.

147 Gilles Veinstein, 'On the Ottoman Janissaries (Fourteenth-Nineteenth Centuries)', in: ErikJan Zürcher, ed., Fighting for a Living: A Comparative History of Military Labour 1500-2000 (Amsterdam, 2013) 115-134; and Virginia H. Aksan, 'Mobilization of Warrior Populations in the Ottoman Context', in: Fighting for a Living, 331-353. 
empire. Apart from the sheer scale and the sophisticated logistics of this army, what made the 'Rumi' model particularly attractive was that emperors-to-be could achieve this without making unfavourable deals, either with the hereditary landed nobility or with stingy mercenary entrepreneurs. Indeed, even in the twenty-first century the military slave system makes an astonishingly modern impression, or as the late Ernest Gellner exclaimed, 'we are all mamluks now' To go on borrowing his words, individuals were recruited into state service in an atomized manner and were torn out of their kin background by being technically slaves. Sustained religious and military training becomes a means of inducing an esprit de corps. Returning to our own topic, although the Janissary corps was certainly not a Chinggisid type of warband, it can be perceived as an artificial, educationally produced alternative to the warband. ${ }^{148}$ In Ibn Khaldun's terms, it is the principle of military slavery that overrules kinship and religion as the most important ingredient of Ottoman 'asabiyya.

Looking for other models further east, the sixteenth-century Ottoman historian Mustafa 'Ali knew perfectly well that of the dynasties of the four great Islamic empires, the Ottomans alone had neither a genealogical mandate for sovereignty like that of the Uzbeks and Mughals, nor a religious one like that of the Safavids. For Ali, though, it was not military slavery, Ibn Khaldun's third ingredient, but universal justice that the Ottomans had as their unique selling point. This was based on his analysis that the old regime of a religiously based universal caliphate broadly identified with the sharica and Arab hegemony had been replaced by a new dispensation of universal nomad dominion under the legitimate sovereignty of Chinggis Khan and his successors, who had received divine sanction to conquer the world and to distribute it to family and followers. To avoid the decline of empire, due to excessive wealth and degeneration, the 'modern' ruler should take care to remain true to his mandate: the dynastic commitment to justice and order made manifest in kanun, which, more than the shari'a, embodies the grace of God. For Ali, history had demonstrated that the Chinggisids were more worthy and effectual sovereigns than the irresponsible, ignorant, and morally corrupt scions of the Abbasid house. Therefore he stressed the legitimating importance of the principle of universal and impersonal justice that the Mongols had implemented in the form of the Chinggisid

148 Ernest Gellner, 'Tribalism and the State in the Middle East', in: Philip S. Khoury and Joseph Kostiner, eds., Tribes and State Formation in the Middle East (London, 1991) 115, 121. In my view Gellner makes too much of 'tribal' cohesion, which may be right for the North African context but much less so for the Eurasian one where not the ascriptive tribe but the conscriptive warband was the dominant model before military slavery. 
dynastic law or yasa. For Ali, the Chinggisid yasa was the same as the Ottoman kanun. It was this dynastic commitment to universal justice in two formsIslamic sharica and dynastic in kanun - coupled with a strong central authority, that constituted the primary legitimating principle of the Ottoman Empire. ${ }^{149}$

It is quite significant that a sixteenth-century Ottoman historian unconsciously paraphrases Ibn Khaldun by referring to the legacy of Chinggis Khan. Despite the introduction of various new sedentary forms of imperial rule, that legacy was still considered very much alive and kicking. Hence, coming full circle in our essay, it is time to reflect on the semantic and historical meaning of the warband as a category of global history by briefly comparing our TurkoMongolian brand of the warband with other variations of what seems to be the same phenomenon in areas without a substantial nomadic Turko-Mongolian impact: North Africa, Western Europe, and South India.

\section{Conclusions}

In an attempt to make sense of periodization in world history, the late Jerry Bentley pointed out that the first half of the second millennium should be called the age of transregional nomadic empires. Nomadic peoples established empires incorporating vast stretches of the Eurasian land mass and sponsored direct interactions between distant peoples. The migrations, conquests, and empire-building efforts of these nomadic peoples guaranteed that crosscultural interactions would take place in a more intensive and systematic fashion than in earlier eras. ${ }^{150} \mathrm{I}$ have attempted to demonstrate that the key to this nomadic success story was the Chinggisid model of the Turko-Mongolian warband. It reverberated far beyond the steppes of Central Asia and was at its most effective not in the Central Zone but in the transitional areas between the northern Middle and Outer Zones. At the same time, I have also stressed that despite its undeniable success, this particular model of the warband could not be maintained in the sedentary world, which, in the long run, won out over the

149 Cornell Fleischer, 'Royal Authority, Dynastic Cyclism, and 'Ibn Khaldûnism' in SixteenthCentury Ottoman Letters', Journal of Asian and African Studies 18 (1983) 198-220.

150 Jerry H. Bentley, 'Cross-Cultural Interaction and Periodization in World History', The American Historical Review 101, no. 3 (1996) 766-767. See also his more elaborate Old World Encounters: Cross-Cultural Contacts and Exchanges in Pre-Modern Times (Oxford, 1993) 111165 . 
nomads. ${ }^{151}$ Here, as we can see in the chapter by Maaike van Berkel, nomadic warriors became Gefundenis Fressen for the people of the pen, who, in numerous mirrors-for-princes, chronicles, and other sophisticated court stories were able to turn them from savage nobles into noble savages. ${ }^{152}$

Looking back at the main qualities of our nomadic warband, we should first of all highlight how it differed from a tribe. A warband was a highly disciplined, meritocratic group of military elites that remained open to talented outsiders. Thus, far from being an ascriptive kinship group like the tribe, it was consciously engineered to mould a new group of mixed ethnic origin. Indeed, as discussed by Marie Favereau in this volume, nomadic leaders took pride in their Chinggisid nasab. This could be particularly pronounced when Mongols faced slaves, as happened in the thirteenth century when the Ilkhanid ruler Ghazan confronted the Mamluks of Egypt. According to the chronicler Rashid al-Din, the lack of lineage was proof that the Mamluk regime was merely a product of chance, devoid of any right to rule. The same condescending attitude on the part of the Mongols is confirmed by Ibn Taymiyya, who, serving as Mamluk representative at the Mongol court, reported that one of the Mongol leaders addressed him, saying: 'Our king is the son of a king, the son of seven generations of kings, while your king is the son of a client'. ${ }^{153}$ However, we should bear in mind that, although such genealogical haughtiness may have been characteristic for the Chinggisid leadership, genealogical tables remained negotiable and in no way prevented the continued reshuffling of its subject people. It was only under conditions of settlement and state-formation in the sedentary world that nasab tended to lose much of its flexibility and become much more fixed. ${ }^{154}$

Not being a tribe, the nomadic warband was neither a royal bodyguard nor an army. The nomadic warband encompassed the 'state', if not the entire society as a whole, with little distinction between military and administrative functions. The nomadic nature and equine power of the Turko-Mongolian warband

\footnotetext{
$15^{1}$ See also the conclusions in Khazanov and Wink, eds., Nomads in the Sedentary World, 292295 .

152 See also Richard van Leeuwen, Narratives of Kingship in Eurasian Empires, 1300-1800 (Leiden and Boston, 2017).

153 Denise Aigle, The Mongol Empire between Myth and Reality: Studies in Anthropological History (Leiden, 2015) 294.

154 See e.g. Sholeh A. Quinn, 'The Uses of Genealogy and Genealogical Information in Select Persianate and Bábí/Bahá'í Sources. A Preliminary Survey', Lights of Irfan 4 (2003) 131140. See also my own comments on Indo-Afghan nasab in my The Rise of the Indo-Afghan, c. $1710-1780$ (Leiden, 1995) 160-175.
} 


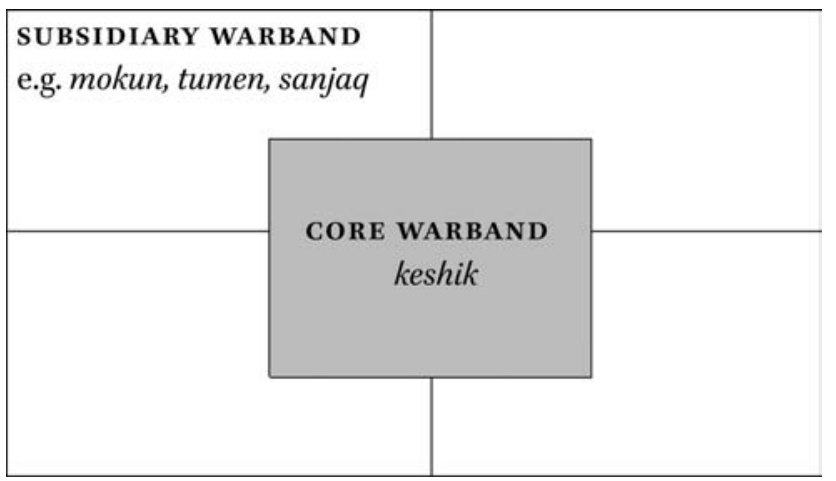

FIGURE 4.2 Basic structure of the nomadic warband

also differentiates it from the more universal and much smaller phenomenon of the comitatus, as described by Beckwith. As we have seen, it was only under the peculiar ecological conditions of the Arid Zone frontiers that the latter developed the capacity to incorporate large segments of society and reshuffled them in consciously created subsidiary warbands under new 'ethnic' labels. The nomadic warband reached its widest expanse and was at its zenith at the very fringe of the Arid Zone and at the very moment just after a conquest when it could exploit the rich sedentary societies without having to give up its one and only trump card: the warhorse.

What we have found is that this particular kind of warband-including its subsidiary replicas - was astonishingly consistent within the political organization of Jurchen, Mongolian, Turkic, Timurid, and Tatar empires. Contemporaries would recognize these empires under the label of ulus, each of which consisted of a core warband or keshik that supported various subsidiary warbands under various denominations, such as mukun under the Jurchen, tümen under the early Timurids, or sanjaq under the early Ottomans. In principle, the empire as a whole was allotted as the appanages of these various subsidiary warbands.

As we have seen, under the sedentary conditions that followed a conquest, these institutions tended to lose their fluidity and either evaporated entirely or solidified under new ascriptive 'banners' that recall the three main ingredients of Ibn Khaldun's 'asabiyya: kinship, devotion, and slavery. Hence, the TurkoMongolian nomadic warband and its post-nomadic offshoots described in this chapter so far are very much the products of the nomadic frontier. 


\section{Epilogue: Counterpoints}

The discussion of the nomadic warband immediately raises questions regarding other types of warbands in the other military zones. What determines the distinction of these warbands from the phenomenon discussed in this Chapter? To start with, to what extent were our Turko-Mongolian warbands really different from those other nomadic tribes and bands, such as the Almohads and Almoravids, who carved out their own states in the Maghreb, the 'wild west' of the Islamic world? 155

\section{The Bedouin Warband: Tribe?}

Although Ibn Khaldun has served as our theoretical model for understanding the process of nomadic and post-nomadic state-formation around Central Asia, we should also be aware that he primarily wrote about developments in his own world, i.e. North Africa. Although both areas experienced similar Ibn Khaldunian cycles between 'desert' and 'city', the ecological conditions of North Africa, including the Iberian Peninsula and the most western parts of the Arab Middle East, were significantly different from those of Central Asia. First of all, on both sides of the nomadic frontier we encounter much smaller and less cohesive political configurations. In the Maghreb and the Middle East the armies were much smaller and used perhaps better but certainly far fewer warhorses. Secondly, the nomadic frontier itself was less sharp than in the eastern Middle Zone, and we actually witness a mosaic of relatively well-integrated and thus less articulated nomadic and sedentary communities. ${ }^{156}$ The historiography on the Bedouins of the Middle East has traditionally stressed the importance of kinship relations (nasab) as a major cohesive force of their ruling elites. ${ }^{157}$ At the same time, there has always been considerable ambivalence in the way historians have interpreted nasab. Most would agree that the term refers to both biological descent and social origin. Most question whether its importance is really a fact of Bedouin life or a mere claim that retrospectively

155 This term derives from Amira Bennison, 'Liminal States: Morocco and the Iberian Frontier between the Twelfth and Nineteenth Centuries', The Journal of North African Studies 6, no. 1 (2001) 11-28.

156 For two excellent studies that take issue with Ibn Khaldun's analysis of North African developments, see A.C. Hess, 'Firearms and the Decline of Ibn Khaldun's Military Elite', Archivum Ottomanicum 4 (1972) 173-201 and Ronald Messier, 'Re-thinking the Almoravids, re-thinking Ibn Khaldun', The Journal of North African Studies 6, no. 1 (2001) 59-80.

157 Stefan Leder, 'Nasab as Idiom and Discourse', Journal of the Economic and Social History of the Orient 58, no. 1-2 (2015) 56-74. 
gave legitimacy to a ruling elite based primarily on non-kinship based social relations. Hence, as in the case of Central Asia, there is a growing tendency to question the idea of the tribe as a political category. Indeed, Ibn Khaldun himself insisted that nasab had no foundation in reality but argued for the social and political expediency of the loyalty that nasab helped to create.

Bedouins can acquire royal authority only by making use of some religious colouring, such as prophethood or sainthood, or some great religious event in general. The reason for this is that because of their savagery, the Bedouins are the least willing of nations to subordinate themselves to each other, as they are rude, proud, ambitious, and eager to be leaders. Their individual aspirations rarely coincide. But when there is religion (among them) through prophethood or sainthood, then they have some restraining influence upon themselves. The qualities of haughtiness and jealousy leave them. It is, then, easy for them to subordinate themselves and to unite. ${ }^{158}$

Hence, it seems that although Bedouin societies were informed by a theory of descent, the actual units of social organization were based on loyalty to successful warrior chieftains, and preferably to prophets or saints.

But as we have indicated in the Turko-Mongolian case, the potential of nasab to incorporate new people after a conquest was quite limited. Most successful large-scale organizations, therefore, depended on using non-tribal models of political organization. As they lacked the economic resources to create massive new warbands like those of Chinggis Khan, Timur, or Nurhaci, the nomadic conquerors of the western Islamic World had to resort to different and more modest policies that appealed to their more egalitarian followers and, at the same time, could sustain their conquests. Those few modern historians who made the comparison between the two cases assert that what really made the Bedouin process of state-formation different from the Turko-Mongolian one was the tendency of the former towards religious chieftainship under a charismatic religious leader. They stress that rulers in the Turkish tradition-with the major exception of the Safavids - saw themselves as patrons and protectors, perhaps even managers of religion, but not as personal repositories of religious knowledge or spiritual power as in the case of relatively weak Bedouin leaders who were mediating rather than ruling over relatively egalitarian segmentary lineages. ${ }^{159}$

158 Ibn Khaldun, The Muqaddimah, 120.

159 Two of the very few collective studies that compare Middle Eastern with Central Asian 
Whatever one may think of these qualitative differences, these cannot be dissociated from an even more important quantitative one: with access to the richest of the world's sedentary societies, Central Asian nomads were capable of far greater expansion than those of the Middle East. As Thomas Barfield states quite convincingly, whereas nomadic groups in the Middle East could muster political or military units only in the tens of thousands, and then only to effectively control their own territories, Turko-Mongolian warbands proved capable of combining hundreds of thousands of people living across vast areas and of employing them militarily for distant campaigns. ${ }^{160}$

Although probably very appealing, the Chinggisid model was never fully implemented by the Bedouin states because it required the mobilization of economic resources available only in the four major frontier zones that we have discussed earlier. Under conditions in which nomads are faced with limited economic resources, it is not the spoils of this world but rather those of the next that work best to create and maintain an empire. It was only thanks to the relatively rich resources of the Nile River valley that the Mamluks of Egypt were able to build a very efficient army of slaves, i.e., one other possible ingredient of Ibn Khaldun's 'asabiyya. Equally telling, though, is the fact that the latter consisted of Turks from, once again, Central Asia! Indeed, as Barfield observes, after the year 100o, the great Middle Eastern empires would all have Central Asian roots.

\section{The Germanic Warband: Comitatus}

Despite this spatial and temporal contingency, Chinggis Khan's warband also appealed to potentates living far beyond its actual radius of operation in the far corners of the External Zone, as well as to others centuries after its nomadic way of life had completely vanished. One of them was Adolf Hitler. In one of his speeches, he made the following comparative observation:

Our strength is in our quickness and our brutality. Genghis Khan had millions of women and children killed by his own will and with a gay heart. History sees only in him a great state builder ...

nomadism are: one by a specialist of the Middle East: Ira M. Lapidus, 'Tribes and State Formation in Islamic History', in: Philip S. Khoury and Joseph Kostiner, eds., Tribes and State Formation in the Middle East (London, 1991) 25-48; the other by a specialist of Central Asia: Thomas J. Barfield, 'Tribe and State Relations: The Inner Asian Perspective', in: idem, $153^{-185}$. See also the telling differences with Central Asia as analyzed by Anatoly M. Khazanov, 'Muhammad and Jenghiz Khan Compared: The Religious Factor in World Empire Building', Comparative Studies in Society and History 35, no. 3 (1993) 461-479.

Barfield, 'Tribe and State Relations', 165. 
Hitler himself was probably inspired by Himmler, who had developed a particular liking for Chinggis Khan after reading two works by the Russian émigré Michael Charrol: Tschingis Chan, der Sturm aus Asien (1934) and Das Erbe Tschingis Chan (1935), both written under the pen name of Michael Prawdin. In 1938 the ss Educational Office ordered a special revised and expanded onevolume edition of these books, which was distributed to Himmler's highest ss officers. Obviously, what attracted both Hitler and Himmler to Chinggis Khan was his splendid career as a world conqueror. Most of all, though, they were inspired by the sheer violence of his conquest and the way that bloodshed could cement the loyalty, or literally Blutkitt, of his followers. As in the case of the sacrifice of animals that accompanied Chinggis Khan's oath or anda with his blood-brother Jamukha, the Nazis thought that bloodstained hands were those most unlikely to desert their leader and his cause. What is more telling for our present purpose, though, is the fact that although the Nazis may have admired Chinggis, this did not keep them from trying to exterminate the Mongol race and from deeply deploring the racial mingling that he undeniably practiced. ${ }^{161}$ The latter point shows how dissimilar the actual Chinggisid warband had grown from the expectations of people in the modern, sedentary societies of Europe where warfare had become the monopoly of national states drawing their manpower from their own national populations.

For historians of the West, the archetypical warband is that of the Celts and Germans as described by Caesar and Tacitus respectively. Of course, what these have in common with the Chinggisid warband is their focus on permanent movement and raiding. As elsewhere, warrior leaders formed hosts of companion warriors, both family members and friends, around them, making warfare their occupation and predatory existence their rationale. As we have seen with the Turko-Mongolian warbands, the so-called convivium, the feast held to foster and strengthen the sense of community, was of great significance in keeping the people committed to their leader.

Despite these and other similarities, for our present purpose the differences are more significant. First of all, the barbarians of the West were primarily foot sloggers. Whereas in the Arid Zone horses were available in large numbers to all members of society, creating mounted hordes that encompassed practically all of society, in Western and Central Europe the horse was confined to the elite and could be kept only as a luxury. In other words, the European warrior elites were able to monopolize horsepower. But even without a large number

161 Richard Breitman, 'Hitler and Genghis Khan', Journal of Contemporary History 25 (1990) 337-351. 
of horses, during their gradual migration into the Roman Empire Germanic comitati were able to create small kingdoms that were ruled in accordance with surviving Roman administrative traditions. Among the Franks, it was Clovis's comitatus of about $400-500$ warriors that managed to incorporate the comitati of defeated rulers. Hence, from the very beginning of the European Middle Ages, the core of kingly power was the comitatus. The latter remained small and could never develop into something that compares to the size and sheer encompassing capacity of the Turko-Mongolian warband. ${ }^{162}$ Instead, after an initial period of migration and state-formation, the relatively open comitatus increasingly took root and transformed into a closed aristocratic household based on territorial control. ${ }^{163}$ By directly linking warriors to landed sources of revenue, the state was able to shortcut and discard the need to circulate revenue through the whole complex, expensive, and cumbersome intermediate medium of administrative bureaucracy. At least from the ninth century onward, three important factors further strengthened the development of a territorially rooted European aristocracy. First, inheritance started to pass strictly down through the male line alone, with the most important property title passing undivided to the eldest son. Secondly, power became centred on a landed lordship embodied in a family castle or a house monastery. Thirdly, kinship ties became immensely important to the status and rank of this new landed nobility. ${ }^{164}$

As aristocratic households became more entrenched in the soil-certainly in comparison with those parts of Eurasia that were exposed to nomadic conquest - the power of the king suffered accordingly, creating the administrative cycles as recently analysed by Victor Lieberman and (in this volume) Jeroen Duindam on a global scale. ${ }^{165}$ Although the idea is reminiscent of Ibn Khal-

162 For a recent survey of the European developments, see Azar Gat, War in Human Civilization (Oxford, 2006) 210-244.

163 For a similar development of the druzhina in Kievan Rus, see F. Feldbrugge, Law in Medieval Russia (Leiden, 2009) 129-145.

164 This is mainly based on German historiography, in particular the very insightful Gerd Althoff, Family, Friends and Followers: Political and Social Bonds in Early Medieval Europe (Cambridge, 2004). Pace important exceptions such as Robert Bartlett and R.I. Moore, it is really striking to see how European medieval historiography on the topic is still splintered along national lines and hardly addresses the outer European scene.

165 Victor Lieberman, Strange Parallels: Southeast Asia in Global Context, c. 800-1830, 2 vols. (Cambridge, 2003-2009). See also Duindam's recent global survey: Dynasty: A Global History of Power, 1300-1800 (Cambridge, 2015). 
dun, the dynamic of the administrative cycle in a fully sedentary environment is significantly different. First of all, European kings were unable to mobilize a group of fresh foreign nomads in order to uproot their increasingly obstreperous nobility - the aforementioned case of the Hungarian king being the most western and latest example of the contrary. Due to a lack of resources it was also difficult, if not impossible, to keep the entire aristocracy on the move, as we have seen, for example, in the case of the Mughals. What was really out of the question was a thorough ethnic reshuffling of a European aristocracy that became increasingly proud of its genealogical lineage and territorial rootedness.

What European rulers could do was control their landed nobility with the help of men who, unlike their own vassals, were dependent bondsmen serving for pay instead of (feudal) obligation. Indeed, at the earliest stages of Germanic state-formation, this role was played by the comitatus; under the more settled conditions of the early Middle Ages, a royal bodyguard. It was only much later, during the fifteenth century, when they could effectively exploit the rapidly increasing resources of interregional trade, that European rulers were able to set up the first standing armies, the so-called companies d'ordonnance. Ideally speaking, the recruits for such armies were supposed to be foreigners who were as much as possible detached from society and loyal to their (pay)master. This is the main reason why the staunchly Catholic fifteenth-century kings of Castile felt no qualms whatsoever in recruiting a Moorish royal guard. ${ }^{166}$ At the same time, we see a growing tendency to hire part-time mercenaries who offered their increasingly professional services in an increasingly monetized and relatively free military labour market. Here, one may wonder why European rulers never resorted to military slavery, as the Mamluks and Ottomans did. For someone like Niccolò Machiavelli, the highly meritocratic and thoroughly indoctrinated mamluks were clearly superior to the opportunistic, treacherous, and volatile mercenaries of Italy, whose suspect motivation was bound to turn them into unreliable supporters. ${ }^{167}$ Still, for kings the proficiency and achievement of mercenaries had many advantages over the prowess and ascription of their knights. Furthermore, the professionalism of these mercenaries, in particular the so-called Switzers and Landsknechte, fully exploited the fruits of a mili-

166 Ana Echevarria, Knights on the Frontier: The Moorish Guard of the King of Castile (14101467) (Leiden, 2009).

167 Gellner, 'Tribalism and the State', 121-126. 
tary revolution that was primarily based on new tactics and weaponry for both infantry and artillery, all of which started to undermine the effectiveness of the aristocracy's military instrument par excellence: the warhorse.

With more and more money and credit available, regional European rulers gradually gained more control over the organization and command of their armies. The part-time armies of foreign mercenaries that still dominated the sixteenth and seventeenth centuries gradually gave way to highly disciplined and standardized standing armies based on national conscription at the end of our period. ${ }^{168}$ Meanwhile, the aristocracy lost much of its landed autonomy and evolved into an obedient service caste acting as officers in the state's ever expanding permanent forces, which were now increasingly dominated by infantry and artillery. ${ }^{169}$ Under the conditions of ongoing military competition between regional states, the latter two branches of the army reached unprecedented levels of drill and discipline. From the middle of the eighteenth century, it was this, in combination with new gunpowder technology, that delivered these armies their victories over their Asian adversaries. It seems that the process as a whole was at its most effective in the representative-inclusive state regimes of Western Europe-France, the Dutch Republic, and Englandwhere taxation could be maximized and new liquid wealth was accumulated through a very effective combination of Church confiscations, public debt, and

168 However, even during the seventeenth and eighteenth centuries, outsourcing remained an important element of this process; David Parrott, The Business of War: Military Enterprise and Military Revolution in Early Modern Europe (Cambridge, 2012).

169 The later European developments are primarily based on the recent surveys of John A. Lynn, 'The Evolution of Army Style in the Modern West, 80o-20oo', The International History Review 18, no. 3 (1996) 505-545, and the edited volume that takes Lynn's periodization as a starting point: Erik-Jan Zürcher, Fighting for a Living: A Comparative History of Military Labour 1500-2000 (Amsterdam, 2013), in particular the contribution by Frank Tallett, 'Soldiers in Western Europe, c. 1500-179o', 135-169. For the continued role of the aristocracy in early modern armies, see Christopher Storrs and H.M. Scott, 'The Military Revolution and the European Aristocracy, c. 1600-180o', War in History 3, no. 1 (1996) 141; for France: Guy Rowlands, 'Louis XIV, Aristocratic Power and the Elite Units of the French Army', French History 13, no. 3 (1999) 303-331; and for England, Roger B. Manning, Swordsmen: The Martial Ethos in the Three Kingdoms (Oxford, 2003). For the early role of mercenaries in the European Middle Ages, see the excellent studies collected in John France, ed., Mercenaries and Paid Men: The Mercenary Identity in the Middle Ages (Leiden, 2008) and also for the later period: D.J.B. Trim, ed., The Chivalric Ethos and the Development of Military Professionalism (Leiden, 2003). 
maritime trade. ${ }^{170}$ Indeed, it was war itself that contributed significantly to the making of strong, cohesive European national states. ${ }^{171}$

We should not forget, however, that the rise of national armies was possible only because, from the tenth century onward, Europe had become immune to occupation by nomadic conquerors. Instead of a succession of big and powerful empires, Europe was characterized by a plurality of dominions. Lacking a real empire, what lingered on was the Roman imperial legacy. In fact, the discrepancy between the imperialist ideal of a single hegemonic power and the reality of many polities launched an intensive competition for political supremacy between would-be empires, and, as can be gleaned from Peter Rietbergen's contribution to this volume, between the Church of Rome and these 'empires'. Over time, their political competition developed its own dynamic. It expanded to a cultural and moral competition that eventually continued independently of its original imperialist impulse.

While having (too) briefly reviewed the European case, it is clear that Europe had to do without the nomadic and post-nomadic warbands as described and defined in this contribution. It simply lacked the ecological circumstances and the resources. Due to its unique capacity to exploit the wealth of the sedentary world, the Chinggisids and Timurids were able to continue and hugely expand the nomadic warband under its post-nomadic avatars of the mukun and the tümen. Similarly, the key to the success of the most powerful of the post-nomadic empires, that of the Qing, was its ability to limit the proliferation of the aristocracy and to neutralize centrifugal forces through the institutionalization of the aristocracy's role within the military and bureaucratic structure of the banners. ${ }^{172}$ The size and political clout of these warbands, under a single leader, were unprecedented and dwarfed the much smaller, less mobile, and much more scattered aristocratic and mercenary armies of Europe. Although unable to create a true empire, relatively small dynasties, such as those of France or Prussia, could still build impressive regional states for themselves by employing ever more professional mercenary troops, which complemented

170 See Maarten Prak and Jan Luiten van Zanden, 'Towards an Economic Interpretation of Citizenship: The Dutch Republic between Medieval Communes and Modern NationStates', European Review of Economic History 10 (2006) 111-146. For the importance of (formal and informal) ways of confiscating Church property, not only in England but across Europe, see the contribution of Peter Rietbergen in this volume.

171 The literature on this is huge, but perhaps the best starting point is still Bruce D. Porter, War and the Rise of the State: The Military Foundations of Modern Politics (New York, 1994).

172 Nicola di Cosmo, 'State Formation and Periodization in Inner Asian History', Journal of World History 10, no. 1 (1999) 37. 
the relatively small royal guards that would gradually grow into larger standing armies, eventually arriving at the levée en masse under Napoleon. Interestingly, it is only at the very end of our period that the standing armies of France, England, the Dutch Republic, and other European states reached the Chinggisid level of the population's military participation. As in the case of the Turko-Mongolian warbands, these huge European armies thrived on their leaders' fiscal capacity to pay for them. There is even another striking similarity between Chinggis Khan and Napoleon: both armies were built on processes of ethnic engineering, the latter, though, not producing the still rather fluid mukuns or tümens of the Chinggisids and Timurids but the more fixed category of the European nations. By 1800 the national armies of Europe had definitively replaced the Turko-Mongolian warband as the prime model of military world power and imperial conquest.

In other words, if there is a European Sonderweg at all, it could be this transformation from chronically failing imperialism to slowly prevailing nationalism. ${ }^{173}$ The example of India demonstrates how successive post-nomadic empires prevented similar developments from happening in what would otherwise seem to have been a fairly comparable sedentary environment.

\section{The Indic Warband: Companions of Honour}

Very much like medieval Europe, the Indian subcontinent before the arrival of the Turks had seen the development of an agrarian aristocracy of an unmistakably noble character; in other words, a hereditary ruling elite with a regal status of its own that cultivated ideals of chivalry. As André Wink observes, prior to the eleventh-thirteenth centuries, without being greatly affected by nomadic upheavals or external invaders, aristocratic power in much of the subcontinent had become associated with land and with lordship over land. As was the case of their European counterparts, Indian aristocrats controlled castles and land that bound families to their localities. Although interregional trade was important, local connections permeated the political world in which they exercised their authority. With the family at the heart of their power, honour and heredity were to become the major preoccupation and determined aristocratic assumptions about rank and status. At the end of the first millennium, this new class of Kshatriya nobility had risen in the expanding agrarian economies of the time, representing a tiny segment of a vast peasant society in the making. ${ }^{174}$

\footnotetext{
173 Caspar Hirschi, The Origins of Nationalism: An Alternative History from Ancient Rome to Early Modern Germany (Cambridge, 2012).

174 This sections heavily builds on André Wink, Al-Hind:The Making of the Indo-Islamic World,
} 
For our present purpose, it is important to stress that part of the chivalrous code of these new Kshatriyas or Rajputs was that kings were accompanied by so-called companions of honour: hundreds to thousands of dedicated warriors who were ready to follow their king in death, often by voluntary selfimmolation. When reading early Muslim authors like Abu Zayd and al-'Umari, who wrote about these 'heroic companions' (bala' al-jar), one is immediately reminded of the astonishment of the Roman authors about the Germanic comitatus. Muslim onlookers regarded them as a typical Indian institution and one of the 'aja'ib al-hind: the marvels of India. For the Turkish conquerors and their slave aristocracies, these fanatical Indian warbands must have been a truly strange phenomenon. In contrast, their mamluks were cut loose from their communities, exchanged on the basis of cash value, and recruited from faraway places. It was in fact their 'lack of honour' and their 'social death' that meant they were closely associated with the person of the king in positions of personal subservience. As with their European counterparts, it was unthinkable that the Indian aristocracy of nobles, with its own notions of what was virtuous and honourable, and which disdained personal subservience, would adopt such a servile attitude. Referring to the Ottoman case, Joseph Fletcher rightfully labelled mamluks 'surrogate nomads', but Wink, looking at the Indian situation, is equally astute in calling them 'surrogate aristocracies.' ${ }^{175}$ Indeed, in early medieval India mamluks played the role that mercenaries played in medieval Europe, i.e. counterbalancing the agricultural nobility, or, as the late Ernest Gellner more succinctly put it: 'the mamluks were the Switzers of the Muslim courts!'176

After the Turkish conquerors had established the Delhi and Deccan Sultanates, and more especially later under the Mughals, military slavery never really took root. Instead, India developed a sophisticated military labour market into which the relatively few mamluks who served the early Muslim courts had to adjust. ${ }^{177}$ At around the same time as in Europe, India gave birth to highly professional war-jobbers of its own, apart from other, more spurious,

Vol. 2: The Slave Kings and the Islamic Conquest, 11th-13th centuries (Leiden, 1997) 170-182, and Norman F. Ziegler, 'Some Notes on Rajput Loyalties during the Mughal Period', in: J.F. Richards, ed., Kingship and Authority in South Asia (Madison, Wisconsin, 1978) 215252.

175 Joseph Fletcher, 'Turco-Mongolian Monarchic Tradition in the Ottoman Empire', Harvard Ukrainian Studies 3/4 (1979-1980) 243; Wink, Al-Hind II, 179.

176 Gellner, 'Tribalism and the State', 124.

177 For a recent discussion of this process, see Sunil Kumar, 'Bandagī and Naukarī: Studying Transitions in Political Culture and Service under the North Indian Sutanates, Thirteenth- 
Rajputs and Turks, in particular Afghans, Marathas, and Nayakas. Some of them even managed to carve out their own states on the basis of their military service. As in early modern Europe, an increasingly vigorous and monetized military labour market began to undermine the position of the landed aristocracy. Under Mughal rule honour increasingly became a monetized commodity, a question of negotiable title deeds to manşab and jagir, which no longer demanded great sacrifice. More generally speaking, imperial clientship and imperial service developed extensively, at the expense of kinship as the basis of political organization.

Although there are many parallels between the development of the warband and military labour market in Europe and India, there is one crucial distinction. Whereas in Europe the idea of a European empire remained a dream, the Turks managed to make empire an Indian reality. As we have stressed already, due to India's open and inner frontier with the Arid Zone this is hardly surprising. The late medieval resurgence of empire in India had major consequences for the process of state-formation on the subcontinent. Whereas Europe could develop relatively autonomous cities and relatively fixed and well-integrated regional states, from the eleventh century India became increasingly characterized by disposable cities and shifting regional capitals and borders. To a large extent, the Mughals could establish their military power on the basis of their control of the military labour market, dwarfing any independent military force that was available to contemporary European rulers. ${ }^{178}$ In India, too, and particularly during the fifteenth and eighteenth centuries, regional aristocracies tried to impose regional centralization, but in all three cases this was nipped in the bud by new imperial formations, be it under Turkish or, in the latter case, under British leadership.

Although keeping to a slightly different chronology, the same holds true for South India, where the kings of Vijayanagara were perceived as himdurayasuratran or 'sultans under the Hindu kings,' and as such were not that distinguishable from their Turkish neighbours of the Deccan. ${ }^{179}$ Here again, regional developments under their seventeenth- and eighteenth-century Nayaka successor states were superseded by imperial British conquest. It is only further to the south, in the rice-producing regions of Southeast Asia, that strong regional

Sixteenth Centuries', in: Francesca Orsini and Samira Sheikh, eds., After Timur Left: Culture and Circulation in Fifteenth Century North India (Delhi, 2014) 6o-111.

178 The comparison is Parrott's (The Business of War, 14).

179 Philip B. Wagoner, 'Harihara, Bukka, and the Sultan: The Delhi Sultanate in the Political Imagination of Vijayanagara', in: David Gilmartin and Bruce B. Lawrence, eds., Beyond Turk and Hindu: Rethinking Religious Identities in Islamicate South Asia (Gainesville, 200o) 316. 


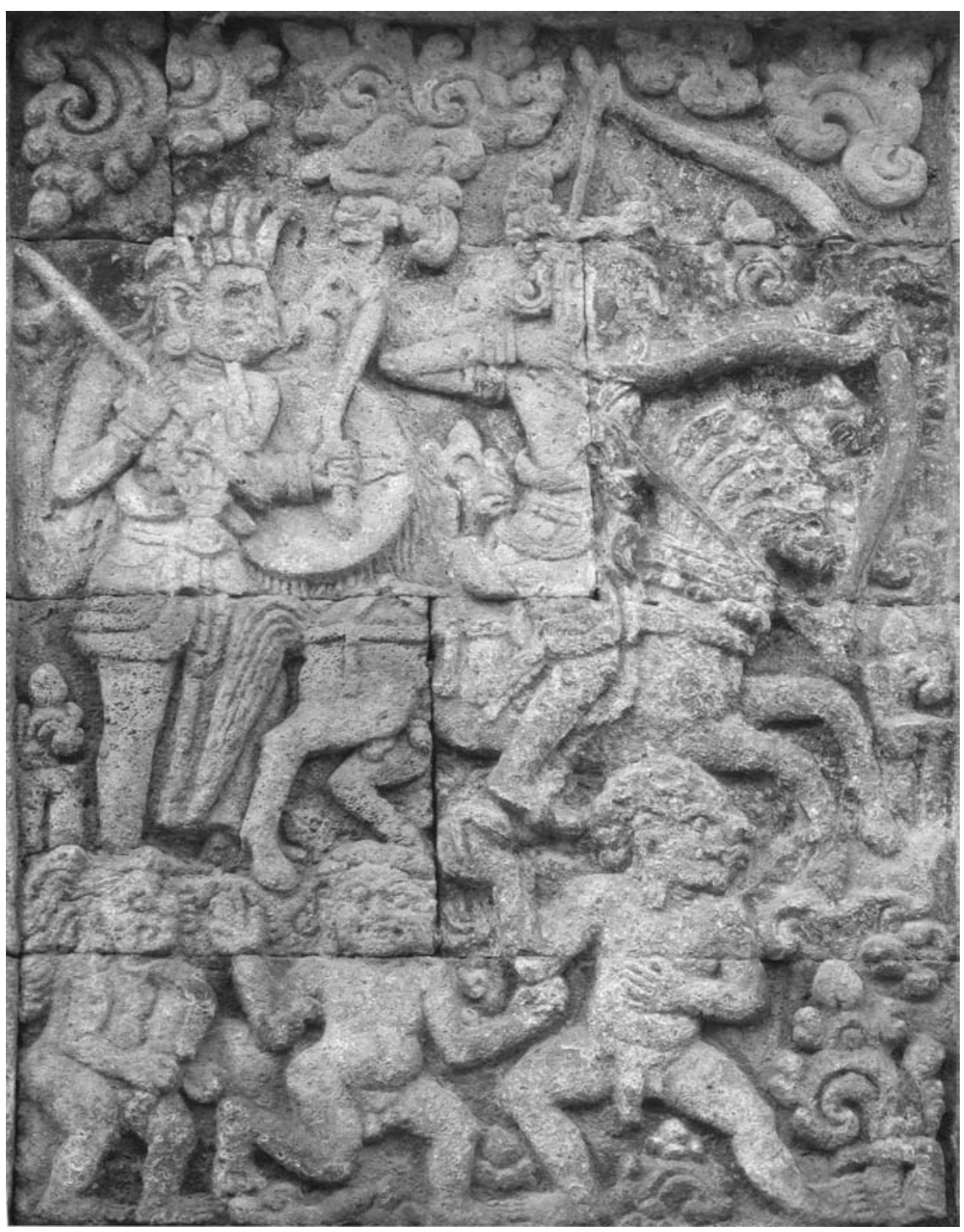

FIGURE 4.3 This relief from the Panataran Temple (c. 1323-1347) shows how the archetypical Mongol horse-archer is inscribed into the Ramayana story of Hanuman's campaign in Lanka to rescue Rama's wife Sita, who had been abducted by the demon king Ravana. We can see Ravana's son Indrajit, riding a multi-snake-headed horse, drawing his bow and shooting a magic snake arrow at Hanuman. ${ }^{180}$ PHOTOGRAPH: JOS GOMMANS, 2014

180 See Ann R. Kinney (with Marijke J. Klokke and Lydia Kieven), Worshipping Siva and Buddha: The Temple Art of East Java (Honolulu, 2003) 179-215. The procedure of inscribing 
kingdoms could develop, allowing the perceptive historian Victor Lieberman to observe the strongest of his 'strange parallels' with Europe, as both were ecologically 'protected' from the repeated onslaught of the nomadic warband. ${ }^{181}$ I was therefore stupefied when, travelling across Java in the summer of 2014, I found on one of the reliefs of the Panataran temple a depiction of the TurkoMongolian mounted warrior. More than a thousand miles away from the steppes of Central Asia, this fascinating example of fourteenth-century globalization may illustrate that even at the most eastward and most sedentary limits of al-Hind, ${ }^{182}$ the Turko-Mongolian nomadic warband was still recognized as a powerful political and cultural emblem of empire. ${ }^{183}$

article by Sheldon Pollock: 'Ramayana and Political Imagination in India', Journal of Asian Studies 52, no. 2 (1993) 261-297.

181 Lieberman, Strange Parallels, vol. 2, 85; see also, more recently, the thought-provoking analysis by Ravi Palat, The Making of an Indian Ocean World-Economy, 1250-1650. Princes, Paddy Fields and Bazaars (London, 2015).

182 Wassaf calls Majapahit: Mul chawa az bilad-i hind, i.e. the core lands of Java in the country of India; André Wink, Al-Hind: The Making of the Indo-Islamic World, Vol. 3: Indo-Islamic Society, 14th-15th Centuries (Leiden, 2004) 223.

183 Of course, the Sino-Mongols invaded Java in 1293 but, considering its tropical environment, it is hard to imagine the horse archer to have had much military impact. It is possible, though, that the Majapahit state that emerged after the invasion was, like Vijayanagara, very much aware of the new political language of 'sultanic' Turko-Mongolian worldpower. 